Article

\title{
Hydrothermal Alteration in the Main Sulfide Zone at Unki Mine, Shurugwi Subchamber of the Great Dyke, Zimbabwe: Evidence from Petrography and Silicates Mineral Chemistry
}

\author{
Jeff B. Chaumba
}

Department of Geology and Geography, University of North Carolina-Pembroke, 211 Old Main, 1 University Dr., Pembroke, NC 28372, USA; chaumba@uncp.edu

Received: 24 May 2017; Accepted: 14 July 2017; Published: 22 July 2017

\begin{abstract}
The main platinum-group element (PGE) occurrence in the Great Dyke of Zimbabwe, the Main Sulfide Zone (MSZ), is a tabular stratabound layer hosted in pyroxenites. A petrographic and silicate composition study across the MSZ at Unki Mine in the Shurugwi Subchamber was conducted to help place some constrains on the origin of the mineralization. The PGE-enriched zone at Unki Mine is a $\sim 10 \mathrm{~m}$ thick package of rocks ranging from gabbronorites, a chromitite stringer, plagioclase websterite, plagioclase pyroxenite (pegmatitic in one narrow zone), a base metal sulfide zone and it is largely located below the contact of the Mafic and Ultramafic Sequences. Pyroxenes have been partially hydrothermally altered to amphibole and chlorite in most lithologies. In addition, sulfides tend to occur as cumulus phases or as inclusions in all the silicate phases. Two generations of sulfide mineralization likely occurred at Unki Mine with primary sulfides occurring in association with cumulus phases, and the relatively finer-grained, often lath-like, sulfides that occur in association with alteration phases of chlorite and amphibole that were likely formed later during hydrothermal alteration. Chlorite thermometry yields temperatures ranging from 241 to $390{ }^{\circ} \mathrm{C}$, and from 491 to $640{ }^{\circ} \mathrm{C}$, and they are interpreted to be temperatures recording the hydrothermal event(s) of magmatic origin which affected the mineralization at Unki Mine. Two-pyroxene thermometry yields temperatures that range from 850 to $981^{\circ} \mathrm{C}$, and these temperatures are interpreted to indicate a hydrothermal imprint on the minerals that constitute the MSZ.
\end{abstract}

Keywords: layered intrusions; Great Dyke; Main Sulfide Zone; mineral chemistry; hydrothermal alteration

\section{Introduction}

Due to the very high partition coefficients between sulfide and silicate melts [1,2], platinum-group elements (PGEs) are preferentially concentrated in immiscible sulfide liquids that separate from silicate magmas. The formation of PGE mineralization in large mafic-ultramafic intrusions, such as the Great Dyke, Bushveld Complex in South Africa, the Stillwater Complex in Montana, USA, and the Noril'sk $\mathrm{Ni}$-Cu-(PGE) deposits in Siberia is therefore commonly thought to be magmatic [3,4]. However, there is also evidence in many PGE deposits in layered intrusions that secondary hydrothermal activity can remobilize base metals and PGEs [5,6].

Hydrothermal alteration has also been considered to be responsible for the mineralogical and chemical variations of the primary base-metal sulfide (BMS) and platinum-group minerals (PGMs) in the Merensky reef in the Bushveld Complex [7] and in the J-M reef of the Stillwater Complex [8-11]. In the Stillwater Complex, researchers such as Boudreau and McCallum (1992) [8] and Boudreau (2016) [12] argue that volatiles played a role in modifying the sequence of mineralization of the evolving parent magma based on the occurrence of high-temperature fluid inclusions in pegmatoids 
and hydrous melt inclusions (now crystallized) in chromite and olivine from both the Ultramafic and the Banded Series rocks, the boninitic character of the parent magma, the presence of volatile-bearing minerals including high-temperature carbonates, rock textures, and $\mathrm{Cl} / \mathrm{F}$ variations in apatite.

The principal platinum-group element (PGE)-bearing horizon in the Great Dyke of Zimbabwe, the Main Sulfide Zone (MSZ), is hosted in orthopyroxenites $[13,14]$. At Unki Mine in the Shurugwi Subchamber of the Great Dyke, a sulfide-enriched horizon termed the base metal sulfide zone (BMSZ) occurs almost $9 \mathrm{~m}$ below the contact of the Mafic and Ultramafic Sequences. At Unki Mine, the MSZ is a $3.2 \mathrm{~m}$ thick horizon within the topmost pyroxenites of the Ultramafic Sequence although the sulfide and PGE-enriched zone extends from orthopyroxenites into the lower part of the overlying gabbroic rocks of the Mafic Sequence. Although some studies have documented silicate assemblages associated with hydrothermal alteration events in PGE-enriched horizons in layered intrusions [15-22], very few of those $[7,10,23,24]$ have focused on the mineral compositions of the altered silicates themselves. Although models on the origin of the MSZ of the Great Dyke are numerous, no mineral composition studies exist that specifically focus on both primary silicate minerals and their alteration products. In carrying out this mineral composition study of the silicate minerals occurring within the Great Dyke's MSZ at Unki Mine, the aim is to document the textures within the silicates and to document the hydrothermal alteration that occurred focusing on mineral compositions of both primary and altered silicate phases.

\section{Brief Outline of the Geology of the Great Dyke}

The Great Dyke of Zimbabwe is one of the world's largest and well studied intrusions. It is a layered mafic-ultramafic intrusion that cuts across the Zimbabwe Archean craton (Figure 1a) and it acts as host to the second largest resource of PGEs in the world. The Great Dyke is composed of two major chambers, the North and South Chambers (Figure 1b) which Wilson and Prendergast (1989) [25] further subdivided into subchambers on the basis of continuity of layering, style, and thickness of cyclic units (Figure 1b). A third and relatively small chamber, the Mvuradonha Chamber, occurs at the extreme north of the dike [25]. 


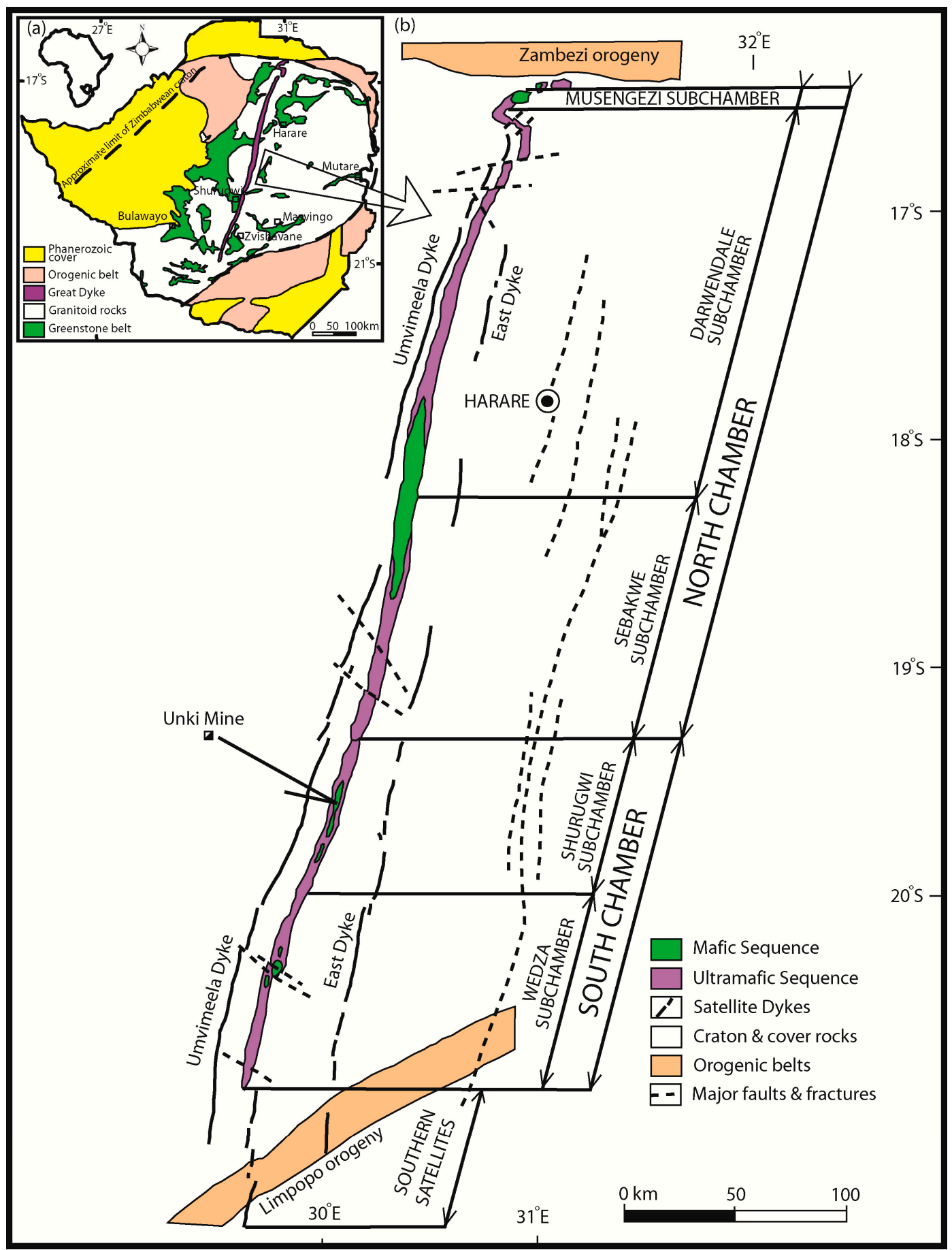

Figure 1. (a) Map showing location of the Great Dyke within the Zimbabwe Archean craton (After Wilson, 1990 [26]) (b) The satellite dykes, major fracture pattern, and faults associated with the Great Dyke are shown here, together with the Chambers and Subchambers of the Great Dyke (after Wilson and Prendergast, 1989 [25]). The location of Unki Mine in the Shurugwi Subchamber is also shown.

The structure of the Great Dyke is synclinal with inwardly dipping layers-the dips increasing from the central axis towards the margins but decreasing again near the walls $[25,27,28]$. At depth, the Great Dyke has a dike-like feeder which in places has been interpreted to be connected to deep-seated magma chambers [29]. The transverse section of the Great Dyke (Figure 2a) has been interpreted to be trumpet-shaped with individual layers thinning away from the axis and eventually becoming 
incorporated in the Border Group which rests against to the Great Dyke walls [25]. The Mafic Sequence and the upper layers of the Ultramafic Sequence may have extended beyond the present margins of the Dyke by several kilometers, and these lateral extensions are thought to have been entirely eroded [29].

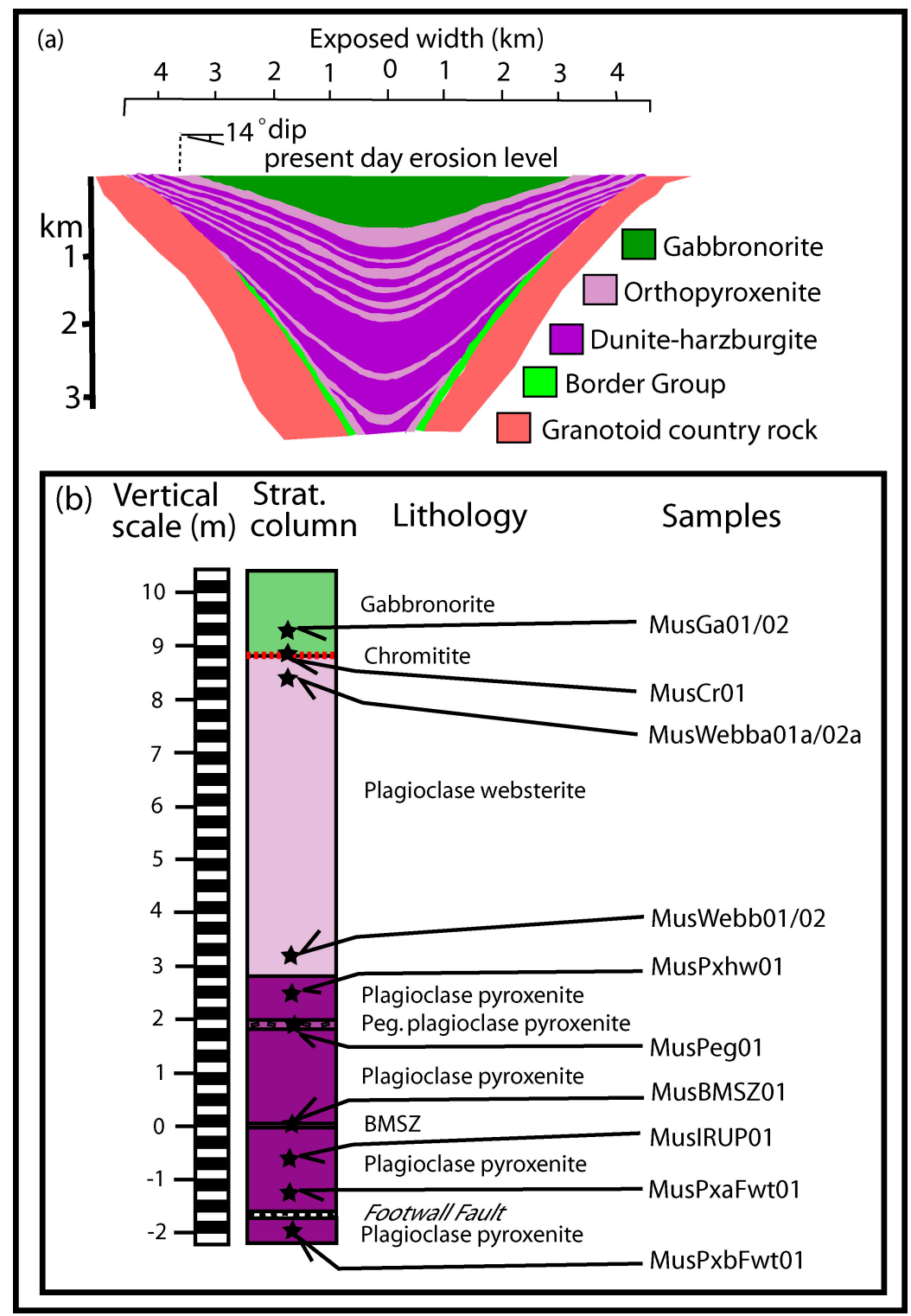

Figure 2. (a) Transverse section of the Great Dyke showing attitude of layering and its relationship to wall rocks [25]. (b) Stratigraphic section in the Unki Mine area showing location of samples used in this study.

The longitudinal section of the layers of the Great Dyke plunges gently towards the center of each subchamber, to form an overall boat-like structure $[27,28]$. The Mafic Sequence, which reaches its maximum thickness in the Darwendale Subchamber, is preserved as remnants in the center of each of the subchambers (Figure 1b) and has been extensively eroded. Here, $2000 \mathrm{~m}$ of the Ultramafic Sequence is overlain by $1150 \mathrm{~m}$ of the Mafic Sequence [30]. The stratigraphic section in the vicinity of Unki Mine in the Shurugwi Subchamber from just above the Mafic Sequence/Ultramafic Sequence contact to the footwall of the mineralized zone is shown in Figure $2 \mathrm{~b}$. Plagioclase pyroxenite is overlain by a $6 \mathrm{~m}$-thick layer of plagioclase websterite which is capped by a very thin chromitite layer (or chromitite stringer) (Figure 2b). Within and above this chromitite stringer occur gabbronorites of the Mafic Sequence 
(Figure $2 \mathrm{~b}$ ). The BMSZ occurs $\sim 3 \mathrm{~m}$ below the plagioclase websterite/plagioclase pyroxenite contact (Figure 2b).

The Ultramafic Sequence in all subchambers is divided into a lower Dunite Succession (1000 m) of dominantly dunite and harzburgite and an upper Bronzitite Succession $(1000 \mathrm{~m})$ of mainly harzburgites and orthopyroxenites (Figure 3) [31]. Cyclic layering is well developed in the Ultramafic Sequence, and in the Shurugwi Subchamber, a total of twelve cyclic units have been recognized [31]. The cyclic units in the Dunite Succession are defined by narrow chromitite layers overlain by dunite layers (Figure 3) [31].

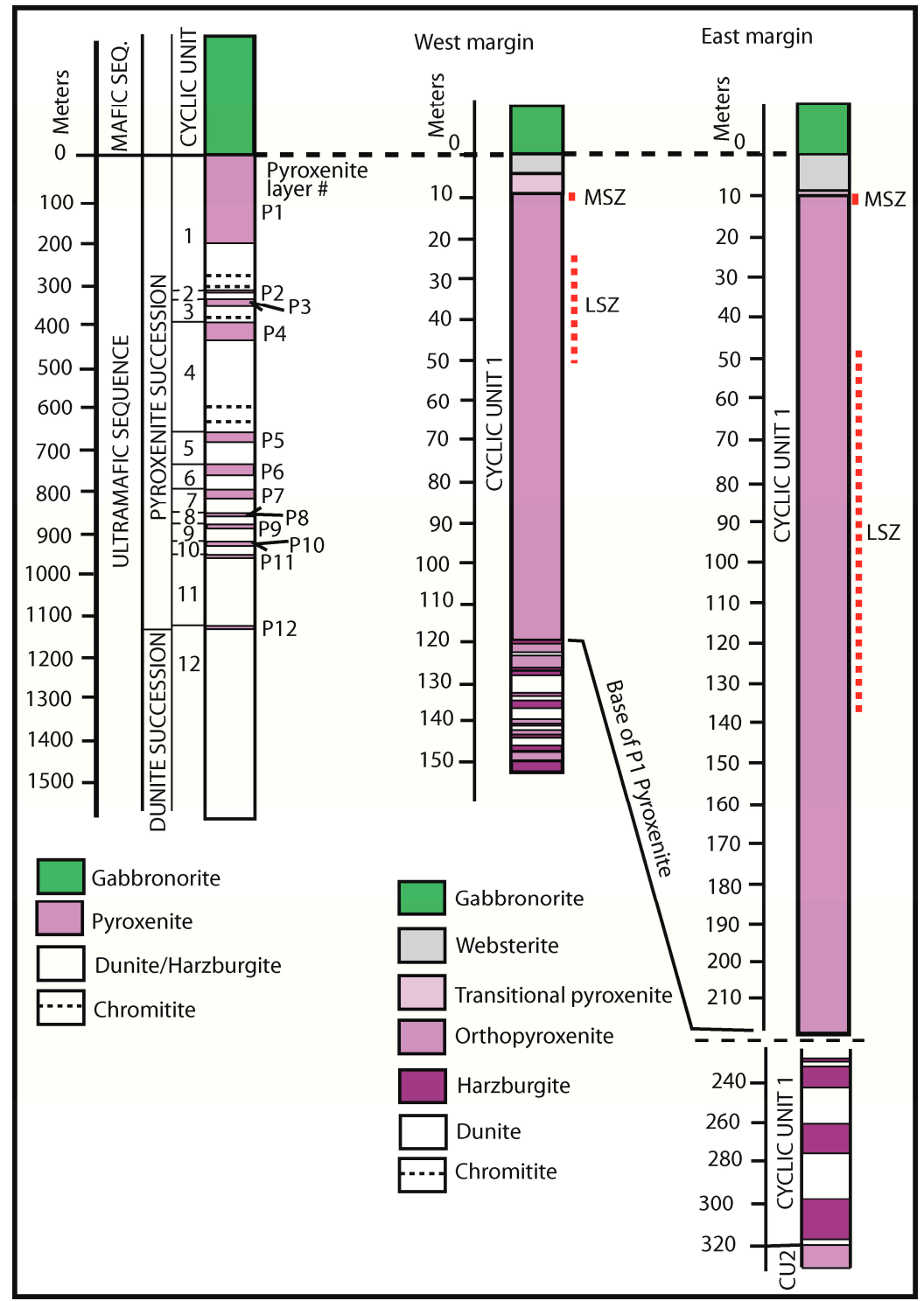

Figure 3. Diagram showing lithostratigraphic sections for the Shurugwi Subchamber (After Wilson et al., 2000) [31]. The complete section, derived from both field and borehole core data, is based on distribution of rock types in the axial region whereas the West and East margins are based on borehole core data from the western and eastern parts of the axial region [31].

In the Bronzitite Succession, however, cyclic units are defined by a complete progression from a basal chromitite layer, through dunite, harzburgite and olivine orthopyroxenite layers to a well-developed orthopyroxenite layer at the top, and as such have been interpreted by Wilson (1982) [32] to represent the ideal cyclic unit of the Great Dyke. Cyclic units such as those occurring in 
the Dunite Succession have, therefore, been interpreted to be incomplete [25]. Six major cyclic units are recognized in the Bronzitite Succession of the Darwendale Subchamber. Chromitite layers occurring in the Ultramafic Sequence which were originally numbered consecutively downwards $[27,28]$, for example, are now numbered according to the cyclic unit in which they occur [13,32]. The cyclic units are interpreted to have been formed by repeated injections of magma followed by fractionation and differentiation [32]. In all the three chambers of the Dyke, the topmost cyclic units 1 and 2 of the Bronzitite Succession are similar [13,33].

Both horizontal and vertical tectonics have been invoked to explain the colinearity of the Great Dyke, its satellites as well as the associated fracture pattern [26,34-36]. According to Wilson (1990) [26], the Great Dyke fracture pattern (Figure 1) can be explained in terms of a progressive craton-wide main deformation model involving SW movement of the Zimbabwe Province relative to the Limpopo Province. Continued deformation of an early crossfold pattern led to intra-block movements on different scales involving major strike-slip deformation zones and thrusting [26]. Continuation of the stress field, which is inferred to have effected the post-Chirumhanzu Suite overthrusting of the Limpopo Province onto the Zimbabwe Province with variation in the direction of maximum compressive stress, is thought to have led to the development of the Great Dyke fracture pattern [26]. Fracturing, overthrusting, and late Achaean main deformation were interpreted by Wilson (1990) [26] to be cratonization responses to a protracted collision between the Zimbabwean and Kaapvaal cratons. Based on U-Pb dating of zircon and rutile from orthopyroxenites of the P1 Pyroxenite layer, the age of the Great Dyke is $2575.4 \pm 0.7 \mathrm{Ma}$ [37]. Further SHRIMP U-Pb studies on the Great Dyke and its satellites by Wingate (2000) [38] yielded a comparable Neoarchean emplacement age of $2574 \pm 2 \mathrm{Ma}$ for baddeleyite.

\section{Occurrence of the Sulfide Mineralization in the Great Dyke and in the Shurugwi Subchamber}

The $90 \mathrm{~km}$-long Shurugwi Subchamber has a shape that has been controlled by its proximity to the Shurugwi greenstone belt (Figures $1 \mathrm{~b}$ and 2), resulting in its deflection and constriction in places [28,39]. At a width of $3.5 \mathrm{~km}$ in its central part, the Shurugwi Subchamber is the narrowest of all the subchambers of the Great Dyke. The Shurugwi Subchamber is important in terms of its petrology because it is the only subchamber that is extensively bounded $(25 \mathrm{~km})$ by greenstones as opposed to the dominantly Archean granites for the other subchambers [28]. The Shurugwi Subchamber abuts against Archean granites on its eastern margin whereas on the western margin, it forms a steep contact mostly with rocks of the Shurugwi greenstone belt (Figure 4a,b). Thus, irregularities in the wall-rocks may have affected the marginal zones of the Shurugwi Subchamber magma chamber and its style of layering [39]. Fine-grained feldspathic pyroxenite, including olivine websterite, forms the Border Group on the west side. The east marginal rocks are largely in contact with granitic rocks and the dip of the contact is $40^{\circ}$ to the west. The eastern margin of the Shurugwi Subchamber is characterized by abundant auto-intrusive granite dykes and pegmatoids resulting from melting of wall-rock and hydrous crystallization. Hybrid lithologies, such as pyroxene-bearing amphibolites, amphibole-bearing pegmatoids, amphibole gabbros and magnetite diorites, are common in the marginal zone as irregularly developed, steeply dipping, fine-grained layers [39].

Cyclic Unit 1 of the Darwendale Subchamber contains several zones of sulfide mineralization [28,40]. Cyclic Unit 1 (Figure 3) is $420 \mathrm{~m}$ thick at the axis of the Dyke in the Darwendale Subchamber and comprises a number of subunits defined on the basis of narrow chromitite layers, repeated stratigraphy, and reversals in mineral compositions [32]. Bichan (1970) [40] identified sulfide mineralization within the lower subunits, with the main metal zones occurring in Sulfide Zones 1 (i), 1 (ii), 1 (iii), 2, and 3 numbered with increasing distance downwards from the Mafic Sequence/Ultramafic Sequence contact [41]. The base of Sulfide Zone 1, the MSZ [42], occurs at the top of the main orthopyroxenite layer and the MSZ extends into the overlying websterite (Figures $2 b$ and 3 ). 


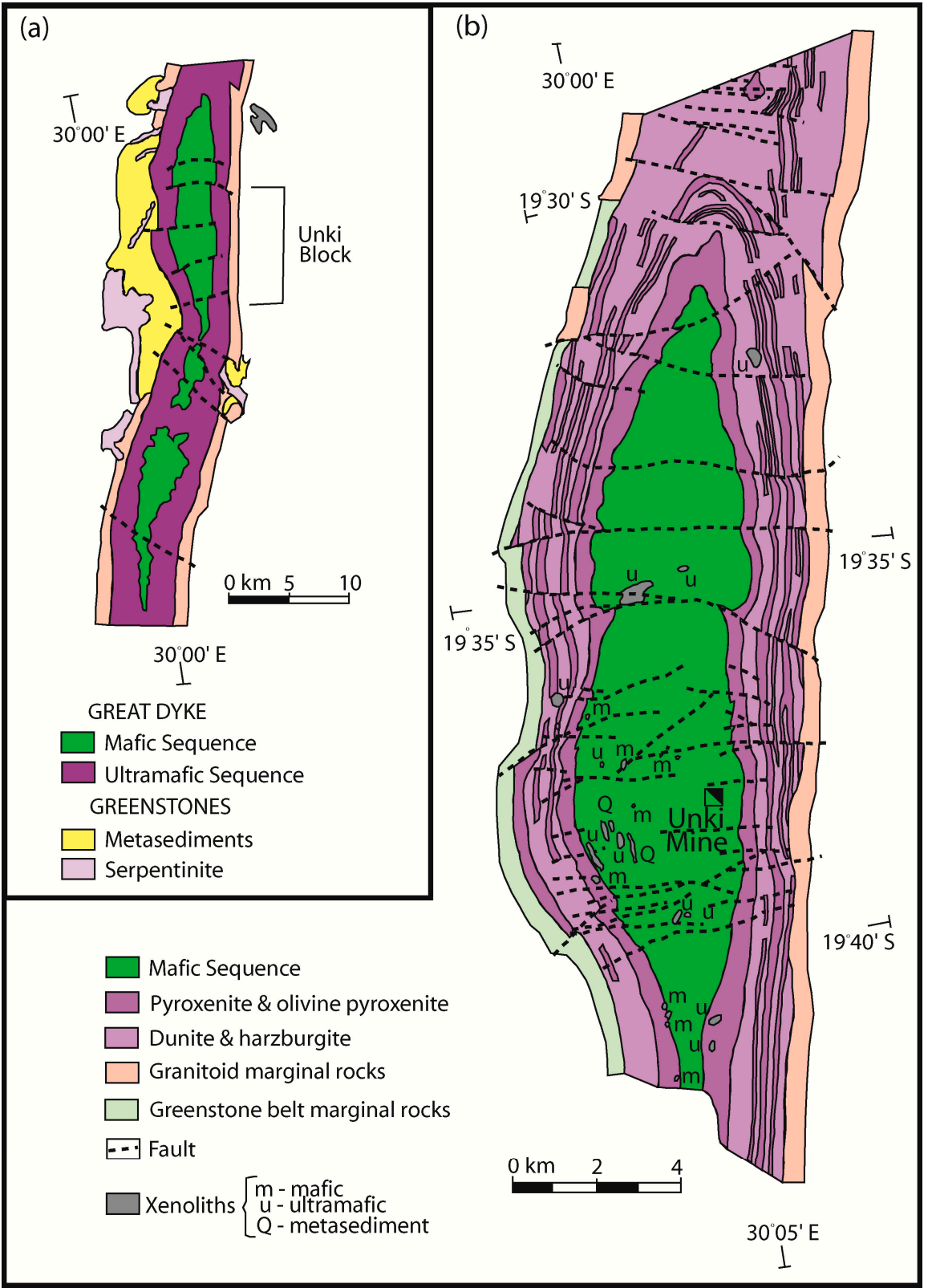

Figure 4. Map showing the geology of the north-central zone of the Shurugwi Subchamber (after Wilson et al., 2000) [31]. Insert (a) with various mining blocks indicated shows location of a simplified map of the Shurugwi greenstone belt on west contact of the subchamber. The main map (b) is an outcrop map covering the Unki Block and parts of Paarl and Helvetia Blocks. Fragments of xenolithic and autolithic suite within the Great Dyke are also shown.

PGE-enriched layers of the Great Dyke also include most of the chromitite layers [37], as well as several silicate horizons in the upper portions of the Ultramafic Sequence [13,14,37,43-45]. According to Oberthür (2002) [46] and Oberthür (2011) [14], up to 2 ppm PGE (Pt/Pd =0.1) occur in the C1d chromitite and its host rocks. PGEs in the Shurugwi Subchamber, as in the rest of the Great Dyke, occur mainly in the tabular and stratabound MSZ. The MSZ is located in orthopyroxenites close to, and overlapping with, the websterite layer and contains up to $6 \%$ sulfide. The more disseminated Lower Sulfide Zone (LSZ), occurring lower in the succession, has lower PGE concentrations than the MSZ and contains up to 1.5\% sulfide [41]. Having been discovered over a century ago [47], the MSZ is similar in form in all the chambers of the Great Dyke $[25,27,28,45]$. In the field, a prominent 
feature of the MSZ is that preferential weathering of the plagioclase oikocryst margins results in the formation of the characteristic nodular texture, or 'potato reef', which is commonly associated with MSZ exposures [47]. The MSZ was originally traced by copper staining, but trenching revealed that the staining was only a surface feature which does not extend at depth [28]. Thus, this copper staining was most likely formed as a result of supergene enrichment.

The width of the MSZ varies from 2 to $8 \mathrm{~m}$ and it contains up to $5 \mathrm{ppm}$ PGE and up to $8 \%$ sulfides over 2-3 m [14,43,46,48,49]. Within the MSZ are the so-called "offset" metal distribution patterns defined by peak Pd levels which occur near the base of the reef, whereas peak $\mathrm{Pt}$ and $\mathrm{Cu}$ levels are reported to occur at progressively higher stratigraphic levels within the MSZ [14,43]. Both the mineralization and the offset pattern are continuous along the strike of the Great Dyke although considerable down-dip variation in the thickness of the MSZ and the amount of sulfides occurs [44]. Mining activity in the MSZ is currently being undertaken at several localities such as at Mimosa Mine in the Wedza Subchamber, at Unki Mine in the Shurugwi Subchamber, and at Ngezi Mine in the Darwendale Subchamber. Sulfides occur as interstitial phases to the cumulus orthopyroxene crystals, and the sulfides are closely associated with late-stage minerals and, where abundant, leading to the formation of a net texture locally [49]. In addition, Wilson (2001) [49] observed that the sulfides have a tendency to concentrate around plagioclase oikocrysts margins, accentuating further the weathering of the nodules.

The thicker LSZ occurs approximately $35 \mathrm{~m}$ stratigraphically below the MSZ, but also within the uppermost P1 Pyroxenite of the Ultramafic Sequence. No petrological break occurs between the MSZ and LSZ. Both the MSZ and LSZ occur in all the subchambers of the Great Dyke in all remnants of the P1 Pyroxenite layer (e.g., Figures 3 and 4). The P1 Pyroxenite consists of tabular to prismatic medium-grained cumulus orthopyroxenes which occur as inclusions in postcumulus plagioclase and clinopyroxene $[25,44,49]$. The LSZ has been investigated from boreholes that intersected it in the Shurugwi Subchamber [49].

Interstitial plagioclase and late-stage minerals such as phlogopite, K-feldspar, quartz, apatite, magnetite, and rarely rutile and zircon also occur in the P1 Pyroxenite [49]. Further, low-grade PGE mineralization has been described in the Middle Mafic Unit of the Mafic Sequence and also in the Mineralized Marginal Zone of the extreme marginal facies of the Border Group [45]. Characteristics of mineralization, rock types, and the different magma chamber structures that occur in the Great Dyke have been described elsewhere $[39,41,43,45,50]$.

The MSZ has been classified as a sulfide hosted, magmatic PGE deposit [39]. The regular distribution pattern of the PGEs in all areas where the MSZ has been investigated have been interpreted to indicate a primary, sulfide controlled fractionation pattern whereby the PGEs have been scavenged from the magma due to their strong partitioning into primary sulfide [41,43]. Analogues of this process were reported in the Munni Munni intrusion of Western Australia [51,52]. Although the MSZ has been identified in all subchambers of the Great Dyke [25,33], lithological details, position, and petrological characteristics are variable even within the same subchamber and they also differ between subchambers. Chromium-spinel occurring in the MSZ from the Darwendale Subchamber is enriched in $\mathrm{TiO}_{2}$ by up to $2.1 \mathrm{wt} \%$ [53].

A common occurrence in the central and western zones of the Shurugwi Subchamber is a suite of xenoliths which range from a meter to several tens of meters in size (Figure $4 a, b$ ), with some exceeding $100 \mathrm{~m}$ in length $[28,39]$. The distribution of the xenoliths in the subchamber is also shown in Figure $4 \mathrm{~b}$. The xenoliths are commonly composed of metasedimentary quartzite and banded iron formation possibly derived from the Wanderer Formation of the Shurugwi greenstone belt [54]. Xenoliths of ultramafic rocks are inferred to be derived from the Shurugwi greenstone belt whereas blocks of chromitite and serpentinite were possibly derived from the Shurugwi greenstone belt [31]. Mafic fragments which occur within the gabbroic rocks and the upper Ultramafic Sequence represent rock types encountered in the Great Dyke with a wide range of mineral compositions that were considered to have been derived from an early formed Border Group of the Great Dyke magma chamber [39]. 


\section{Materials and Methods}

Samples utilized in this study were collected from a stratigraphic zone straddling the MSZ at Unki Mine, currently the only PGE Mine in the Shurugwi Subchamber (Figure 2b), and sample descriptions are provided in Table 1. Samples were collected from the overlying gabbronorites of the Mafic Sequence (samples MusGa01/02), through the MSZ to its footwall (sample MusPxbFwt01) (Figure 2b; Table 1). Sample MusCr01 is from the chromitite stringer occurring right at the Ultramafic Sequence-Mafic Sequence contact (Figure 2b; Table 1), with the rest of the samples being from the plagioclase websterite (MusWebb01a/02a and MusWebb01/02), plagioclase pyroxenite (MusPxHw01 and MusPxbFwt01), pegmatoidal plagioclase pyroxenite (MusPeg01), and the base metal sulfide zone (MusBMSZ01) (Figure 2b; Table 1). Table 2 shows the cumulus minerals, alteration minerals, and the extent of alteration in the suite of samples studied. The difference between the plagioclase websterite and the pegmatoidal plagioclase websterite is that the plagioclase pyroxenite has more than $90 \%$ orthopyroxene whereas the plagioclase websterite has less than $90 \%$ orthopyroxene. Thus, although the plagioclase pyroxenite is actually a plagioclase orthopyroxenite, the term plagioclase pyroxenite is used in this work in order to be consistent with the terminology in use at Unki Mine. The iron replacement ultramafic pegmatite sample (MusIRUP01) is also located within the plagioclase pyroxenite (Figure 2b). The IRUPs, which probably formed from the differentiation of iron-rich residual melts, are discordant bodies within the Unki Mine layered sequence, similar to those described from the Bushveld Complex [55,56].

The footwall fault (Figure 2b) is encountered in the plagioclase pyroxenite and it often marks the base of the stope width and it is unreliable as a reef marker horizon at Unki Mine. The footwall fault, which is talcose, causes slippery conditions when wet thereby affecting the effective use of trackless mobile machines at Unki Mine and it is therefore an undesirable feature for smooth mining operations.

Table 1. Samples from Unki Mine MSZ and adjacent rocks*.

\begin{tabular}{|c|c|c|}
\hline Sample I.D. & Strat. Location & Description \\
\hline MUSGa01/02 & $\begin{array}{l}\text { Mafic unit, }-10 \mathrm{~cm} \\
\text { above the lower contact }\end{array}$ & $\begin{array}{l}\text { Medium grained light greenish brown gabbronorite with relative abundances } \\
\text { as follows: } \mathrm{Pl}>\mathrm{Opx}>\mathrm{Cpx} \text {. }\end{array}$ \\
\hline MUSCr01 & $\begin{array}{l}\text { Mafic/Ultramafic contact } \\
(10 \mathrm{~m} \text { above BMSZ) }\end{array}$ & $\begin{array}{l}\text { Dark/black chromite stringer with chromium dissemination in places and } \\
\text { course grained sulfides (Po, Ccp \& Py). }\end{array}$ \\
\hline MUSWeba01/02 & $\begin{array}{l}\text { Immediately below the } \\
\text { gabbronorite contact } \\
(10 \mathrm{~m} \text { above BMSZ) }\end{array}$ & $\begin{array}{l}\text { Medium grained green brown acicular Pl websterite, needle like and flaky } \\
\text { pyroxenes and fine disseminated sulfides (up to 3\% S) Cpx > Opx = Pl. }\end{array}$ \\
\hline MUSWebb01/02 & $\begin{array}{l}\text { Websterite/Pl pyroxenite } \\
\text { gradational contact } \\
(100 \mathrm{~mm} \text { above contact) }\end{array}$ & $\begin{array}{l}\text { Green/grey brown medium grained plagioclase websterite (transition) with } \\
\text { short stubby and elongated Opx crystals and course disseminated sulfides } \\
\text { (up to } 5 \% \mathrm{~S} \text { ) acicular Pl decreasing towards contact. }\end{array}$ \\
\hline MUSPxhw01 & $\begin{array}{l}\text { Hanging wall of the } \\
\text { BMSZ }(50 \mathrm{~cm}) \text { - Reef }\end{array}$ & $\begin{array}{l}\text { Grayish brown medium grained Pl pyroxenite with course disseminated } \\
\text { sulfides (up to } 6 \% \mathrm{~S} \text { )-Reef Base metal subzone }\end{array}$ \\
\hline MUSPeg01 & $\begin{array}{l}6-8 \mathrm{~m} \text { below the } \\
\text { websterite/Pl websterite } \\
\text { contact }(0.75-1 \mathrm{~m} \\
\text { above BMSZ) }\end{array}$ & $\begin{array}{l}\text { Course grained grayish brown pegmatoidal plagioclase pyroxenite } \\
\text { (course Opx, Pl, and Cpx crystals-grains up to } 2 \mathrm{~cm} \text { ) and course net } \\
\text { textured sulfides. }\end{array}$ \\
\hline MUSBMSZ01 & $\begin{array}{l}\text { BMSZ (10 m below } \\
\text { websterite contact-Reef) }\end{array}$ & $\begin{array}{l}\text { Grayish brown medium grained plagioclase pyroxenite with course } \\
\text { disseminated sulfides (up to } 6 \% \text { S) - Reef and marker horizon }\end{array}$ \\
\hline MUSIRUP01 & Below footwall & $\begin{array}{l}\text { Course grained grayish brown pegmatoidal plagioclase pyroxenite with large } \\
\text { Cpx oikocrysts, no hydromagmatic alteration and sulfide mineralization. }\end{array}$ \\
\hline MUSPxafwt01 & $\begin{array}{l}\text { Above the footwall fault, } \\
50 \mathrm{~cm} \text { below BMSZ }\end{array}$ & $\begin{array}{l}\text { Grayish brown medium grained poikilitic Pl pyroxenite with fine } \\
\text { disseminated and patchy sulfides (up to } 1.5 \% \text { S)-Reef-PGE subzone }\end{array}$ \\
\hline MUSPxbfwt01 & $\begin{array}{l}\text { Below the footwall fault } \\
\text { (1.65 } \mathrm{m} \text { below BMSZ) }\end{array}$ & $\begin{array}{l}\text { Grayish brown medium grained, highly poikilitic and granular } \mathrm{Pl} \text { pyroxenite, } \\
\text { no hydromagmatic alteration. }\end{array}$ \\
\hline
\end{tabular}

* Mineral abbreviations as in Whitney and Evans (2010) [57]; BMSZ—base metal sulfide zone. 
Table 2. Samples from Unki Mine MSZ and adjacent rocks, with cumulus minerals and hydrothermal alteration minerals *.

\begin{tabular}{|c|c|c|c|}
\hline Sample I.D. & Stratigraphic Location & Cumulus Minerals & $\begin{array}{l}\text { Alteration Minerals \& Extent } \\
\text { of Hydrothermal Alteration }\end{array}$ \\
\hline MUSGa01/02 & $\begin{array}{c}\text { Mafic Sequence, } 0.2 \mathrm{~m} \text { above Mafic } \\
\text { Sequence/Ultramafic Sequence contact }\end{array}$ & $\begin{array}{c}\mathrm{Pl}, \mathrm{Cpx}, \mathrm{Opx} \\
\text { postcumulus } \mathrm{Pl}, \mathrm{Cpx}\end{array}$ & Weakly altered Pl \\
\hline MUSCr01 & Mafic/Ultramafic contact $(0 \mathrm{~m})$ & $\begin{array}{l}\text { Chr, Pl, Opx, } \\
\text { postcumulus Cpx }\end{array}$ & Amp (extensive), Chl (weak) \\
\hline MUSWebb01a/02a & $\begin{array}{c}0.2 \mathrm{~m} \text { below Mafic Sequence/Ultramafic } \\
\text { Sequence contact }\end{array}$ & Cpx, Opx, Pl & $\begin{array}{l}\text { Amp (extensive), } \\
\text { Chl (extensive) }\end{array}$ \\
\hline MUSWebb01/02 & $\begin{array}{c}\text { Websterite/Pl pyroxenite gradational contact } \\
\text { (5.8 m below Mafic Sequence/Ultramafic } \\
\text { Sequence contact) }\end{array}$ & Opx, Cpx, & $\begin{array}{l}\text { Amp (extensive), } \\
\text { Chl (extensive) }\end{array}$ \\
\hline MUSPxhw01 & $\begin{array}{c}\text { Hanging wall of the BMSZ (6.2 m below } \\
\text { Mafic Sequence/Ultramafic Sequence } \\
\text { contact)-Reef }\end{array}$ & Opx, Pl oikocrysts & Chl (very weak) \\
\hline MUSPeg01 & $\begin{array}{l}6.8 \mathrm{~m} \text { below Mafic Sequence/Ultramafic } \\
\text { Sequence contact }(0.75-1 \mathrm{~m} \text { above BMSZ) }\end{array}$ & $\begin{array}{l}\text { Megacrystic Pl, } \\
\text { Opx, Cpx }\end{array}$ & Amp (moderate) \\
\hline MUSBMSZ01 & $\begin{array}{c}\text { BMSZ ( } 8.8 \mathrm{~m} \text { below Mafic } \\
\text { Sequence/Ultramafic Sequence contact) }\end{array}$ & $\begin{array}{c}\text { Opx, Cpx } \\
\text { (coarse sulfides) }\end{array}$ & $\begin{array}{c}\text { Amp (extensive), Chl (weak), } \\
\text { Qz (silicification) }\end{array}$ \\
\hline MUSIRUP01 & $\begin{array}{l}9.4 \mathrm{~m} \text { below Mafic Sequence/Ultramafic } \\
\text { Sequence contact, Below footwall }\end{array}$ & $\begin{array}{c}\text { Opx, Cpx, } \\
\text { intercumulus } \mathrm{Pl}\end{array}$ & $\begin{array}{l}\text { Amp (extensive), } \\
\text { Chl (moderate) }\end{array}$ \\
\hline MUSPxafwt01 & $\begin{array}{l}10.2 \mathrm{~m} \text { below Mafic Sequence/Ultramafic } \\
\text { Sequence contact, } 50 \mathrm{~cm} \text { below BMSZ }\end{array}$ & Opx, Cpx, (sulfides) & Chl (weak) \\
\hline MUSPxbfwt01 & $\begin{array}{l}10.6 \mathrm{~m} \text { below Mafic Sequence/Ultramafic } \\
\text { Sequence contact ( } 1.65 \mathrm{~m} \text { below BMSZ) }\end{array}$ & Opx (andedral) & Chl (moderate) \\
\hline
\end{tabular}

* Mineral abbreviations as in Whitney and Evans (2010) [57].

Thin sections were examined first examined using a petrographic microscope, followed by analyzing silicate minerals using an electron microprobe on polished thin sections. Mineral compositions of the minerals were obtained by the use of a JEOL JXA-8530F Hyperprobe housed at Fayetteville State University, North Carolina, USA [58]. For all silicate samples, the Hyperprobe was operated at a beam current of $15 \mathrm{nA}$, an accelerating voltage of $15 \mathrm{kV}$, and a minimum beam diameter of $1 \mu \mathrm{m}$. Images were acquired with both an electron detector and a backscattered electron detector which provides morphology to visualize different phases. Compositions were analyzed first by X-ray energy dispersive spectroscopy (EDS) for qualitative and semi-quantitative analysis, and then by X-ray wavelength dispersive spectroscopy (WDS) for quantitative analysis using Smithsonian and Astimex standards. At least three spots were collected for each phase. Fifteen-second counting times were used on peak and background measurements.

Precision for an element was determined by comparing the results of numerous measurements as well as calculating the standard deviation of the sample [59]. Accuracy and precision of the results of the microprobe analyses were evaluated by repeat analyses of standards shown in tabular form in Supplementary Materials. Standards analyzed as unknowns were used to check the accuracy and precision of analyses. Relative to published values, results from the present investigation are both precise and accurate as shown in Supplementary Materials.

For the calculation of the oxides, the ZAF matrix correction system of Armstrong (1988) [60] was used. In order to accurately calculate the atoms per formula unit (apfu) of the ferromagnesian minerals, one needs to know the $\mathrm{Fe}^{2+} / \mathrm{Fe}^{3+}$ ratio of the iron, and since the microprobe cannot distinguish the valence state of the elements, the $\mathrm{Fe}^{2+} / \mathrm{Fe}^{3+}$ ratio for ferromagnesian minerals was determined based on charge balance.

Chlorite has been used to estimate of temperatures of the hydrothermal alteration that affected the MSZ since a systematic relationship occurs between chlorite formation temperature and aluminum in the tetrahedral site $\left(\mathrm{Al}^{\mathrm{iv}}\right)$, as well as the relationship between temperature and Fe in the octahedral site [61-63]. For low temperature chlorites, use was made of a thermodynamic-activity composition 
model of Lanari et al. (2014) [64]. The occurrence of both orthopyroxene and clinopyroxene, as in rocks under investigation, can permit one to calculate both pyroxene thermometry and pyroxene barometry $[65,66]$. Pyroxene thermometry employed in this work is based on either the calcium content of orthopyroxene or the aluminum-in-orthopyroxene barometer [65], or both, whereas equations based on regression and activity modeling were employed by Putirka (2008) [66].

\section{Results}

\subsection{Petrography of the MSZ at Unki Mine}

In the stratigraphically topmost sample from the section under investigation (MusGa02), a gabbronorite, generally medium-grained crystals of plagioclase occur in association with clinopyroxene. The clinopyroxene shows evidence of alteration in the form of a cloudy appearance (Figure 5a). The plagioclase is polysynthetically twinned (Figure 5a). Clinopyroxene has a tendency to occur as an interstitial phase to plagioclase crystals (Figure 5a). The clinopyroxene crystals in gabbronorites often display twinning (Figure $5 b$ ).

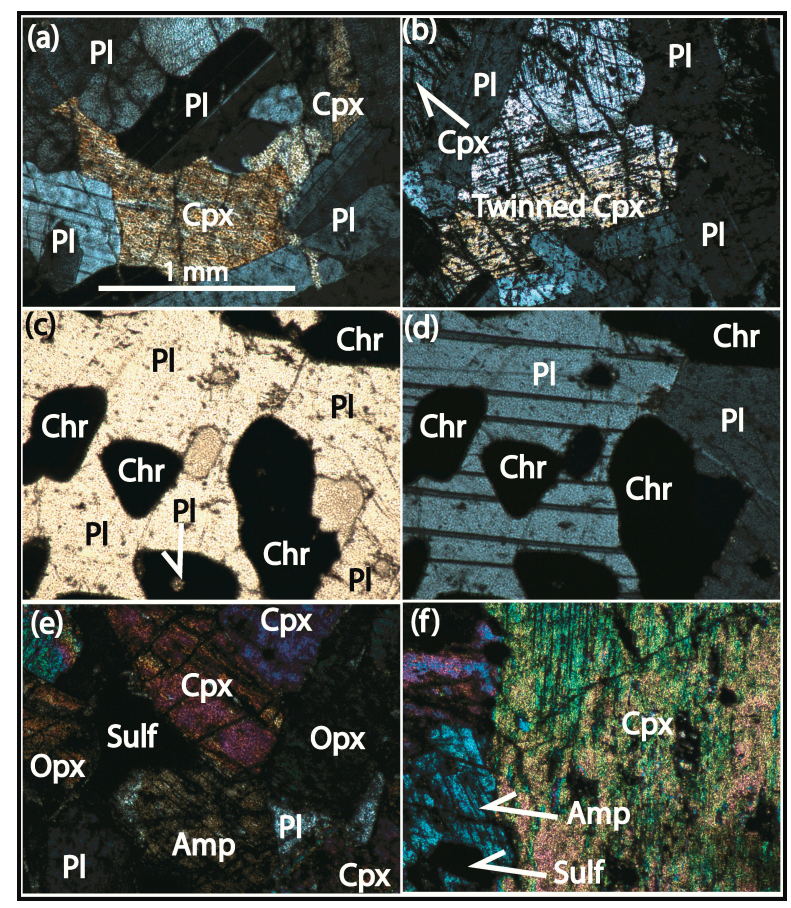

Figure 5. Scale bar shown in (a) is the same for all photomicrographs. (a) Photomicrograph showing polysynthetically twinned plagioclase (Pl) occurring association with clinopyroxene (Cpx). The clinopyroxene is altered, and is interstitial to plagioclase crystals (crossed polars, sample MusGa02). In (b), from the same thin section, a clinopyroxene crystal occurring just to the left of center shows twinning. In addition to clinopyroxene, plagioclase is the only other mineral shown (crossed polars). In the sample with the chromitite stringer (Sample MusCR01), minute fine- to medium-grained euhedral to subhedral chromite crystals occur enclosed within poikilitic plagioclase crystals ((c), plane polarized light and (d), crossed polars). Some of the chromite crystals occur at the intersection of differently oriented plagioclase crystals. Cumulus and altered clinopyroxene and orthopyroxene (Opx) occur together with intercumulus sulfides (Sulf) in sample MusWebb01a (e,f), crosses polars). Plagioclase occurs an intercumulus phase (e), whereas amphibole (Amp) with characteristic cleavage can be seen occurring adjacent to clinopyroxene, with sulfides occurring as inclusions within crystals of amphibole (f).

Within the chromitite stringer (sample MusCR01), occurring stratigraphically below the gabbronorite sample, minute fine- to relatively coarser-grained euhedral to subhedral chromite crystals 
typically occur wholly enclosed within poikilitic plagioclase crystals (Figure $5 c, d$ ). However, some of the fine-grained chromite crystals in this sample also occur at the intersection of differently oriented plagioclase crystals (Figure 5c,d).

Occurring stratigraphically below the chromitite stringer in plagioclase websterite are cumulus and altered clinopyroxene and orthopyroxene crystals together with intercumulus sulfide crystals (Figure 5e,f; sample MusWebb01a). In the plagioclase websterite, plagioclase crystals tend to occur as intercumulus phases but amphibole, with characteristic cleavage (Figure 5f), also occurs together with clinopyroxene. Very fine-grained sulfide crystals in this sample occur as inclusions within very coarse-grained amphibole crystals (Figure 5f). Numerous alteration minerals such as chlorite and amphibole are common in the lower parts of the plagioclase websterite. Here fine-grained altered cumulus clinopyroxene and altered intercumulus plagioclase crystals occur together with chlorite and amphibole crystals (Figure 6a,b; sample MusWebb01).

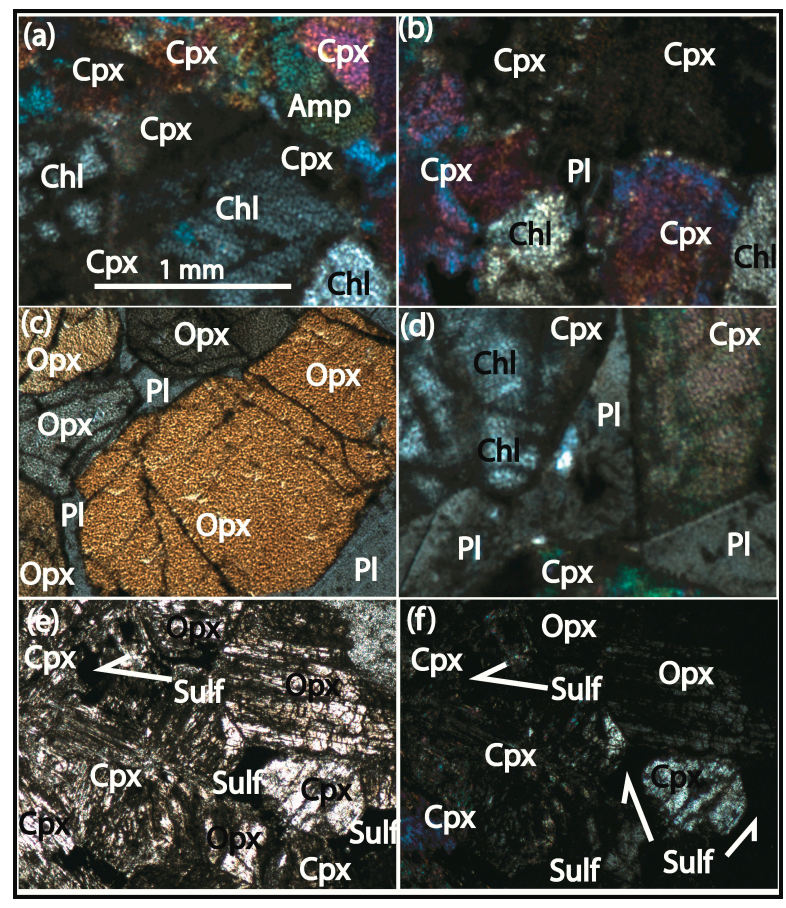

Figure 6. Scale bar shown in (a) is the same for all photomicrographs. (a,b) Photomicrographs showing numerous alteration minerals of chlorite ( $\mathrm{Chl}$ ) and amphibole (Amp) occurring with relict cumulus clinopyroxene (Cpx) and relict intercumulus plagioclase (Pl) under crossed polars (sample MusWebb01). Most of the crystals in $(\mathbf{a}, \mathbf{b})$ are fine- to medium-grained. (c) Sample MusPxHw01 under crossed polars showing coarse-grained euhedral to subhedral cumulus orthopyroxene (Opx) enclosed by poikilitic plagioclase. In (d), euhedral to subhedral clinopyroxene crystals occurs within poikilitic plagioclase, with the clinopyroxene altering to chlorite, crossed polars, sample MusPeg01; note the different scale bar in (d). (e) plane polarized light and (f) crossed polars: Sulfides (Sulf) occurring both within and as intercumulus phases both clinopyroxene and orthopyroxene crystals. The pyroxenes have been altered. Crossed polars, sample BMSZ01.

Within the pegmatoidal plagioclase pyroxenite, which occur stratigraphically below the plagioclase websterite, coarse-grained and euhedral to subhedral cumulus orthopyroxene crystals are enclosed by poikilitic plagioclase crystals (Figure 6c; sample MusPxHw01). Orthopyroxene is the dominant cumulus phase, and no alteration minerals were observed within the pegmatoidal plagioclase pyroxenite. However, just below the pegmatoidal plagioclase pyroxenite, both chlorite and amphibole occur together. Here, euhedral to subhedral clinopyroxene crystals occur within poikilitic plagioclase, with crystals of clinopyroxene altering to chlorite crystals (Figure 6d; sample MusPeg01). 
Occurring stratigraphically below the pegmatoidal plagioclase pyroxenite is plagioclase pyroxenite, and a base metal sulfide zone is located within this plagioclase pyroxenite. Within the BMSZ, fine-grained sulfide crystals occur either within, or as an intercumulus phase, to both mediumto coarse-grained clinopyroxene and orthopyroxene crystals (Figure 6e,f; sample BMSZ01).

Very coarse-grained clinopyroxene crystals occur enclosed within poikilitic plagioclase crystals within the plagioclase pyroxenite which occurs stratigraphically below the BMSZ. The poikilitic plagioclase crystals often display polysynthetic twinning as shown in Figure 7a,b (sample MusIRUP01). Hydrothermally altered clinopyroxene and orthopyroxene have a tendency to occur together with anhedral plagioclase crystals which occupy the interstices between the pyroxenes (Figure 7a,b). Clinopyroxene crystals in plagioclase pyroxenite tend to display twinning (Figure 7a). The footwall to the economic zone is also located within the plagioclase pyroxenite (sample PxaFwt01). In the sample from the footwall zone (MusPxaFwt01) are found very fine-grained and minute sulfide grains which are interstitial to orthopyroxene crystals (Figure 7c,d). Amphibole occurs as an alteration product of orthopyroxene within the footwall zone (Figure 7c,d). Both fine- to medium-grained euhedral orthopyroxene and clinopyroxene crystals and anhedral intercumulus plagioclase are encountered within the lower footwall zone which is located below the upper footwall zone (Figure 7e,f; MusPxbFwt01). In summary, although igneous phases are widespread within the MSZ at Unki Mine, alteration minerals of chlorite and amphibole are also common.

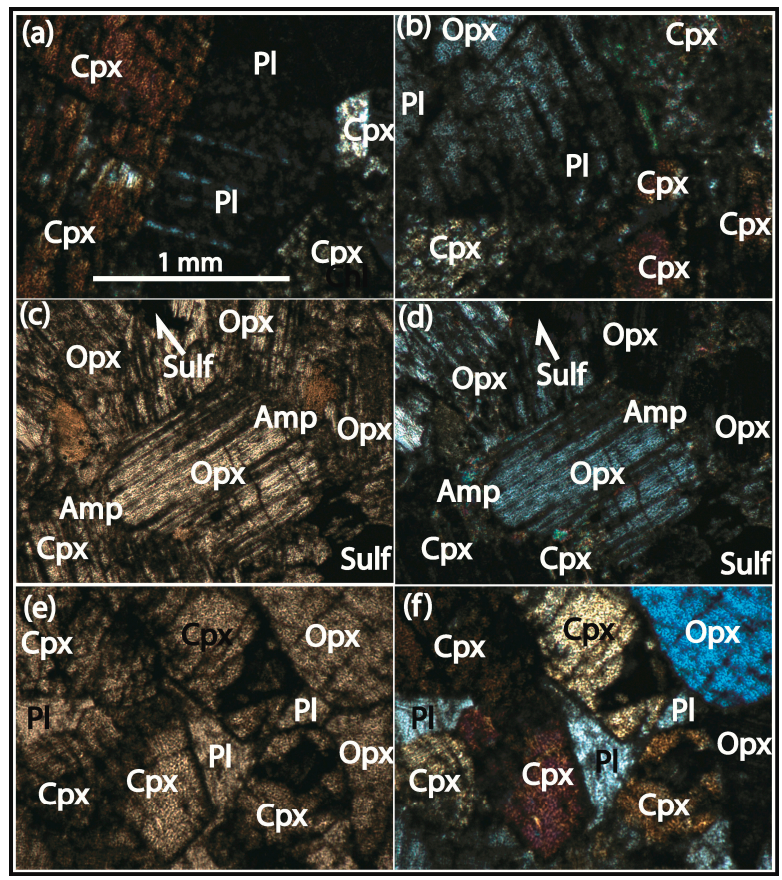

Figure 7. Scale bar shown in (a) is the same for all photomicrographs. (a,b) crossed polars, sample MusIRUP01: shown in (a) are very coarse-grained clinopyroxene (Cpx) crystals enclosed by poikilitic plagioclase $(\mathrm{Pl})$ displaying polysynthetic twinning. Both clinopyroxene and plagioclase are hydrothermally altered. Shown in (b) are hydrothermally altered clinopyroxene and orthopyroxene (Opx) with anhedral plagioclase occupying the interstices between the pyroxenes. Near the center on the right of the photomicrograph is a twinned fine-grained clinopyroxene crystal. (c,d) are views in plane polarized light and crossed polars, sample PxaFwt01 showing very fine-grained sulfide grains interstitial in orthopyroxene crystals. Amphibole (Amp) occurs as an alteration product of orthopyroxene. Both fine- to medium-grained euhedral orthopyroxene and clinopyroxene and anhedral intercumulus plagioclase under plane polarized light (e) and under crossed polars (f), MusPxbFwt01. 


\subsection{Unki Mine MSZ Textural Relationships Revealed by Backscattered Electron Images}

Within gabbronorites from the Mafic Sequence, coarse-grained cumulus clinopyroxene and plagioclase crystals are common, although intercumulus plagioclase grains can also be observed in places between cumulus clinopyroxene crystals (Figure 8a, sample MusGa02). Sulfides in gabbronorites tend to be very fine-grained, typically less than $5 \mu \mathrm{m}$ in size, and they occur as inclusions in both clinopyroxene and plagioclase crystals.

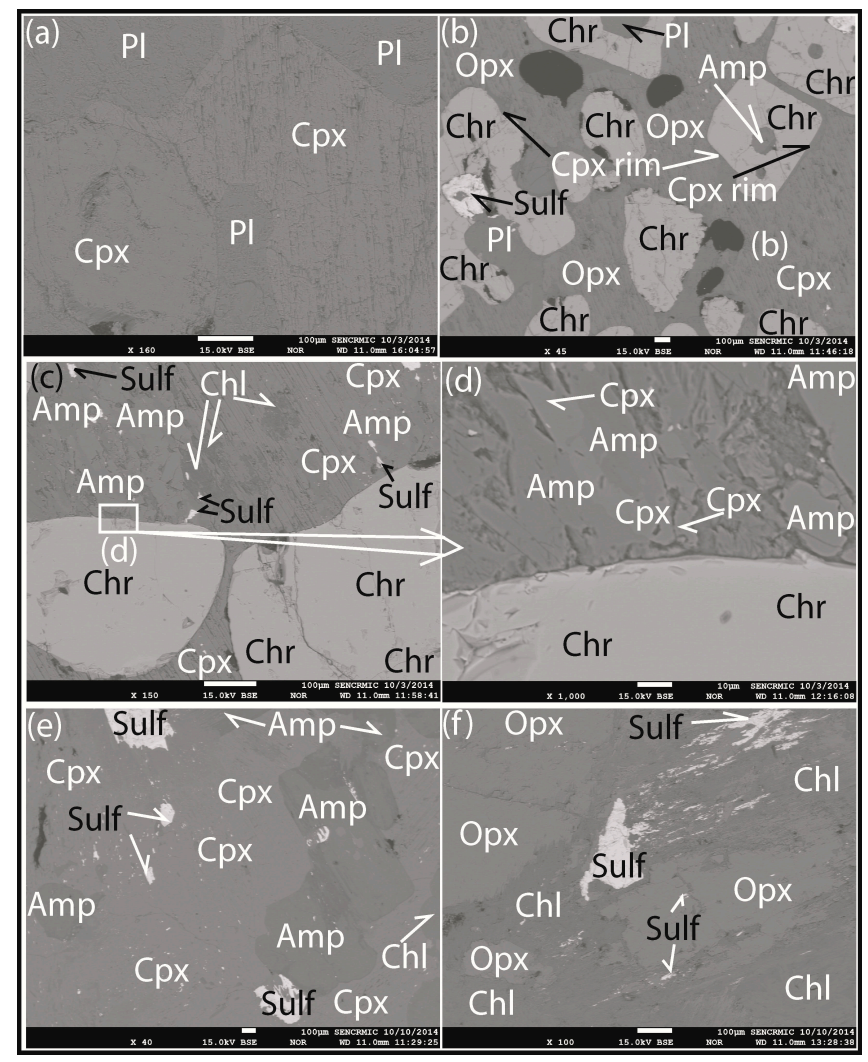

Figure 8. (a) Backscattered electron (BSE) image showing plagioclase and clinopyroxene lacking sulfide crystals from the gabbronorite (sample MusGa02) from the Mafic Sequence. (b-d) are BSEs from sample MusCr01 within the chromitite stringer at the contact between the Ultramafic and Mafic Sequences. (b) Chromite crystals enclosing very fine-grained plagioclase and amphibole crystals and also partially enclose sulfide crystals with plagioclase, clinopyroxene and orthopyroxene being the other crystals. (c) Chlorite and amphibole both replacing clinopyroxene. Micron-size sulfide crystals are enclosed in both amphibole and clinopyroxene crystals (c). (d) Close-up of (c) showing amphibole replacing clinopyroxene crystals with very fine-grained inclusions of sulfides in both. (e) Amphibole replacing clinopyroxene with numerous very fine-grained sulfide inclusions in both minerals. The relatively coarser-grained sulfides are included only in clinopyroxene (sample MusWebb02a). (f) fine- to relatively coarser-grained sulfides occurring as laths within chlorite relatively finer-grained sulfide amounts occurring within orthopyroxene crystals (sample MusWebb02).

Within the chromitite stringer, sulfides occur enclosed in chromite, plagioclase, orthopyroxene, clinopyroxene, chlorite, and amphibole crystals (Figure 8b-d; sample MusCr01). Sulfide crystals occurring in association with chromite crystals are coarser-grained relative to those that occur as inclusions in silicate minerals (Figure 8b-d).

In the plagioclase websterite occurring stratigraphically below the chromitite stringer, sulfides of varying sizes, from a few microns to $\sim 600 \mu \mathrm{m}$ in diameter, occur as inclusions in clinopyroxene crystals (Figure 8e; sample MusWebb02a). Where clinopyroxene has been altered to amphibole, the sulfides 
also occur as inclusions within amphibole crystals, although the relatively coarser-grained sulfides (600 $\mu \mathrm{m}$ across) tend to be associated with clinopyroxene crystals rather than the amphibole crystals (Figure 8e). In some instances, both fine-grained to relatively coarser-grained sulfides tend to occur as laths within alteration minerals such as chlorite, with adjacent orthopyroxene crystals characterized by insignificant amounts and relatively finer-grained sulfide crystals (Figure 8f; sample MusWebb02).

Within the topmost part of the plagioclase pyroxenite which occurs stratigraphically below the plagioclase websterite, coarser-grained $(\sim 500 \mu \mathrm{m}$ in size) sulfides occur in association with coarse-grained orthopyroxene crystals (Figure 9a; sample MusPxHw01). The coarse-grained cumulus orthopyroxenes contain inclusions of very fine-grained sulfide crystals, although the cumulus plagioclase tends to be almost free of such fine-grained sulfide inclusions (Figure 9a). A narrow band ( $20 \mathrm{~cm}$-thick) of pegmatitic plagioclase pyroxenite contains both cumulus orthopyroxene and plagioclase crystals (Figure 9b; sample MusPeg01). Some of the orthopyroxene crystals display the typical orthopyroxene crystal habit (Figure 9b).

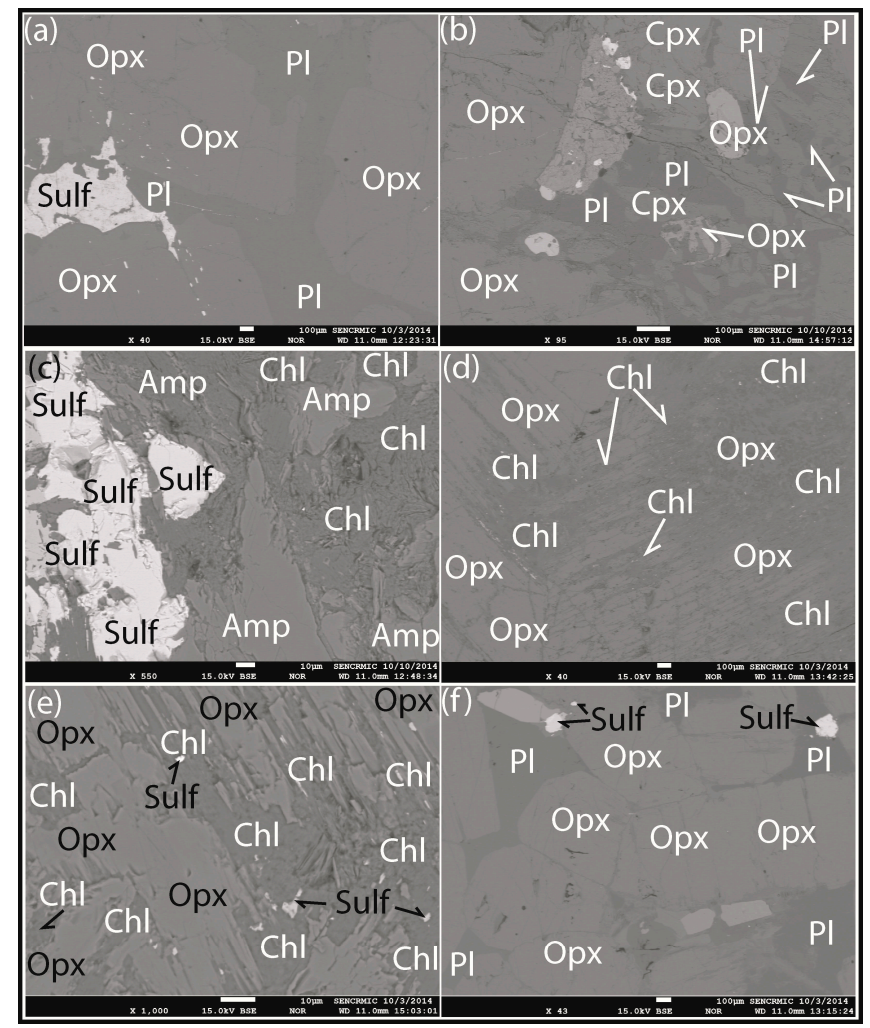

Figure 9. (a) Coarse-grained ( $>2 \mathrm{~cm}$ in size) sulfides occur in association with coarse-grained orthopyroxene (Opx) crystals which contains inclusions of very fine-grained sulfides (Sulf) (sample MusPxHw01). Notice that the cumulus plagioclase (Pl) is almost free of such fine-grained sulfide inclusions (a). (b) A narrow band of pegmatitic plagioclase pyroxenite contains cumulus orthopyroxene (displaying the typical orthopyroxene cross-section) and plagioclase (sample MusPeg01). (c) Abundant relatively coarse-grained sulfides in the base metal sulfide zone which occurs close occurring in association with alteration phases of chlorite (Chl) and amphibole (Amp) (sample MusBMSZ01). (d) Chlorite occurring as a common alteration phase in association with orthopyroxene (sample IRUP01). Note laths of sulfides also occur in association with the chlorite (d). (e) Sulfide inclusions occurring within the cumulus orthopyroxene crystals with chlorite occurring in association with numerous and elongated sulfide crystals (sample MusPxaFwt01). (f) Cumulus orthopyroxene, intercumulus plagioclase, together sulfides which occur either as intercumulus phases or as inclusions in both orthopyroxene and plagioclase (sample MusPxbFwt01). 
Very coarse-grained sulfides (Figure 9c; sample MusBMSZ01) are abundant in the BMSZ which occurs close to $2 \mathrm{~m}$ below the pegmatoidal pyroxenite. Associated with the BMSZ are crystals of both chlorite and amphibole (Figure 9c). In the IRUP zone, chlorite is a common mineral which occurs in association with orthopyroxene as shown in Figure 9d (sample IRUP01). Fine lath of sulfide crystals also occur in association with the chlorite crystals (Figure 9d).

In the footwall to the MSZ just above the footwall fault, orthopyroxene is the dominant cumulus phase, and sulfide inclusions occur within orthopyroxene crystals (Figure 9e; sample MusPxaFwt01). Chlorite is also a widespread mineral here, it occurs in association with orthopyroxene and as well as in association with numerous, elongated sulfide crystals (Figure 9e). Below the footwall fault is another footwall sample to the MSZ which lacks chlorite but is dominated by cumulus orthopyroxene and intercumulus plagioclase, with sulfides occurring either as intercumulus phases or as inclusions in both orthopyroxene and plagioclase crystals (Figure 9f; sample MusPxbFwt01).

\subsection{Unki Mine MSZ Silicate Mineral Chemistry}

Silicate mineral phases that were observed and analyzed by the electron microprobe are orthopyroxene, clinopyroxene, plagioclase, potassium feldspar, chlorite, and amphibole. Orthopyroxene is the dominant mineral in the rocks under this investigation, and 410 analyses of orthopyroxene were obtained in all the samples investigated for this study, with the only exception being in the topmost gabbronorite sample. Table 3 lists representative orthopyroxene analyses, and all orthopyroxene analyses are listed in Supplementary Materials. Typical orthopyroxene analyses have $\sim 54 \mathrm{wt} \% \mathrm{SiO}_{2}$, $\sim 0.1 \mathrm{wt} \% \mathrm{TiO}_{2}, \sim 29 \mathrm{wt} \% \mathrm{MgO}, \sim 12 \mathrm{wt} \% \mathrm{FeO}$, and $\sim 1.5 \mathrm{wt} \% \mathrm{CaO}$ (Table 1). Orthopyroxene Mg\#s $\left[100 \mathrm{Mg} /\left(\mathrm{Mg}+\mathrm{Fe}^{2+}\right)\right]$ range from a low of 75.4 (sample MusPxaFwt01) occurring in the footwall to the MSZ and a high of 97.2 (sample MusPxHw01) (Figure 10a). The majority of the samples, however, have Mg\#s that fall between 77 and 86 (Figure 10a). The lithologic variations across the entire section studied are shown in Figure 10b, as in other similar diagrams that follow. Average Mg\#s across the MSZ display a spiked pattern (Figure 11a). The lowest average Mg\# of 79 occurs in the footwall to the MSZ (sample MusPxaFwt01) whereas the highest average Mg\# of 87 occurs in orthopyroxenes in the topmost part of the Ultramafic Sequence within the chromitite stringer (sample MusCr01). Two spikes to higher average Mg\#s can be observed in Figure 11a, one in plagioclase pyroxenite (sample MusPeg01) at a depth of $-6.8 \mathrm{~m}$ (Figure 11b) and another one in pegmatoidal plagioclase pyroxenite (sample MusIRUP01) at a depth of $-9.4 \mathrm{~m}$ (Figure 11b). Plotted on a pyroxene classification diagram, all the orthopyroxenites are enstatites, with pigeonites also present in the investigated sequence (Figure 12a).

Table 3. Representative orthopyroxene analyses in wt \%.

\begin{tabular}{ccccccccc}
\hline Point & $\mathbf{6}$ & $\mathbf{4 0}$ & $\mathbf{1 2 4}$ & $\mathbf{4 4}$ & $\mathbf{5 4}$ & $\mathbf{2 0}$ & $\mathbf{1 0}$ & $\mathbf{3 0}$ \\
\hline \multirow{2}{*}{ Sample } & $\mathrm{CR01}$ & Webb01a & Webb01a & Webb01 & PXHFW01 & Peg01 & BMSZ01 & PXBFWT01 \\
& $\mathrm{P} 6$ & $\mathrm{P} 40$ & $\mathrm{P} 124$ & $\mathrm{P} 44$ & P54 & P21 & P10 & P30 \\
\hline Depth $(\mathrm{m})$ & 0.00 & -0.20 & -0.20 & -5.80 & -6.20 & -0.80 & -8.80 & -10.60 \\
$\mathrm{SiO}_{2}$ & 55.71 & 54.26 & 54.00 & 55.91 & 54.87 & 54.60 & 55.42 & 53.97 \\
$\mathrm{TiO}_{2}$ & 0.10 & 0.18 & 0.11 & 0.12 & 0.05 & 0.13 & 0.17 & 0.08 \\
$\mathrm{Al}_{2} \mathrm{O}_{3}$ & 1.31 & 1.22 & 1.31 & 1.44 & 0.92 & 1.61 & 0.47 & 1.20 \\
$\mathrm{Cr}_{2} \mathrm{O}_{3}$ & 0.50 & 0.33 & 0.22 & 0.45 & 0.09 & 0.60 & 0.23 & 0.42 \\
$\mathrm{FeO}$ & 8.37 & 13.18 & 12.74 & 12.67 & 13.83 & 11.47 & 12.55 & 13.16 \\
$\mathrm{MnO}$ & 0.24 & 0.24 & 0.38 & 0.27 & 0.30 & 0.27 & 0.28 & 0.24 \\
$\mathrm{MgO}$ & 31.36 & 28.78 & 28.59 & 27.10 & 28.76 & 28.72 & 29.56 & 27.71 \\
$\mathrm{CaO}$ & 0.69 & 1.30 & 1.93 & 1.62 & 0.71 & 2.35 & 0.76 & 1.53 \\
$\mathrm{Na} 2 \mathrm{O}$ & 0.03 & bdl & bdl & 0.03 & 0.01 & 0.03 & bdl & 0.05 \\
$\mathrm{Total}$ & 98.35 & 99.52 & 99.29 & 99.62 & 99.55 & 99.78 & 99.43 & 98.40 \\
\hline
\end{tabular}


Table 3. Cont.

\begin{tabular}{ccccccccc}
\hline Point & $\mathbf{6}$ & $\mathbf{4 0}$ & $\mathbf{1 2 4}$ & $\mathbf{4 4}$ & $\mathbf{5 4}$ & $\mathbf{2 0}$ & $\mathbf{1 0}$ & $\mathbf{3 0}$ \\
\hline \multicolumn{7}{c}{ Cations based on 6 oxygens } \\
\hline $\mathrm{Si}$ & 1.981 & 1.944 & 1.938 & 2.013 & 1.968 & 1.945 & 1.981 & 1.962 \\
$\mathrm{Ti}$ & 0.003 & 0.005 & 0.003 & 0.003 & 0.001 & 0.003 & 0.005 & 0.002 \\
$\mathrm{Al}$ & 0.055 & 0.052 & 0.055 & 0.061 & 0.039 & 0.068 & 0.020 & 0.051 \\
$\mathrm{Cr}$ & 0.014 & 0.009 & 0.006 & 0.013 & 0.003 & 0.017 & 0.006 & 0.012 \\
$\mathrm{Fe}^{3+}$ & 0.000 & 0.040 & 0.057 & 0.000 & 0.021 & 0.020 & 0.003 & 0.012 \\
$\mathrm{Fe}^{2+}$ & 0.249 & 0.355 & 0.326 & 0.382 & 0.394 & 0.321 & 0.372 & 0.388 \\
$\mathrm{Mn}$ & 0.007 & 0.007 & 0.012 & 0.008 & 0.009 & 0.008 & 0.009 & 0.007 \\
$\mathrm{Mg}$ & 1.663 & 1.537 & 1.529 & 1.455 & 1.538 & 1.525 & 1.575 & 1.502 \\
$\mathrm{Ca}$ & 0.026 & 0.050 & 0.074 & 0.062 & 0.027 & 0.090 & 0.029 & 0.060 \\
$\mathrm{Na}$ & 0.002 & 0.000 & 0.000 & 0.002 & 0.001 & 0.002 & 0.000 & 0.004 \\
$\mathrm{Total}$ & 4.000 & 4.000 & 4.000 & 4.000 & 4.000 & 4.000 & 4.000 & 4.000 \\
$\mathrm{En}$ & 85.79 & 77.55 & 77.01 & 76.62 & 77.66 & 77.95 & 79.58 & 76.57 \\
$\mathrm{Fs}$ & 12.85 & 19.93 & 19.25 & 20.10 & 20.96 & 17.46 & 18.96 & 20.40 \\
$\mathrm{Wo}$ & 1.36 & 2.52 & 3.73 & 3.29 & 1.38 & 4.59 & 1.46 & 3.04 \\
$\mathrm{Mg} \#$ & 86.98 & 81.26 & 82.44 & 79.22 & 79.61 & 82.60 & 80.89 & 79.46 \\
\hline
\end{tabular}

Bdl-below detection limit.

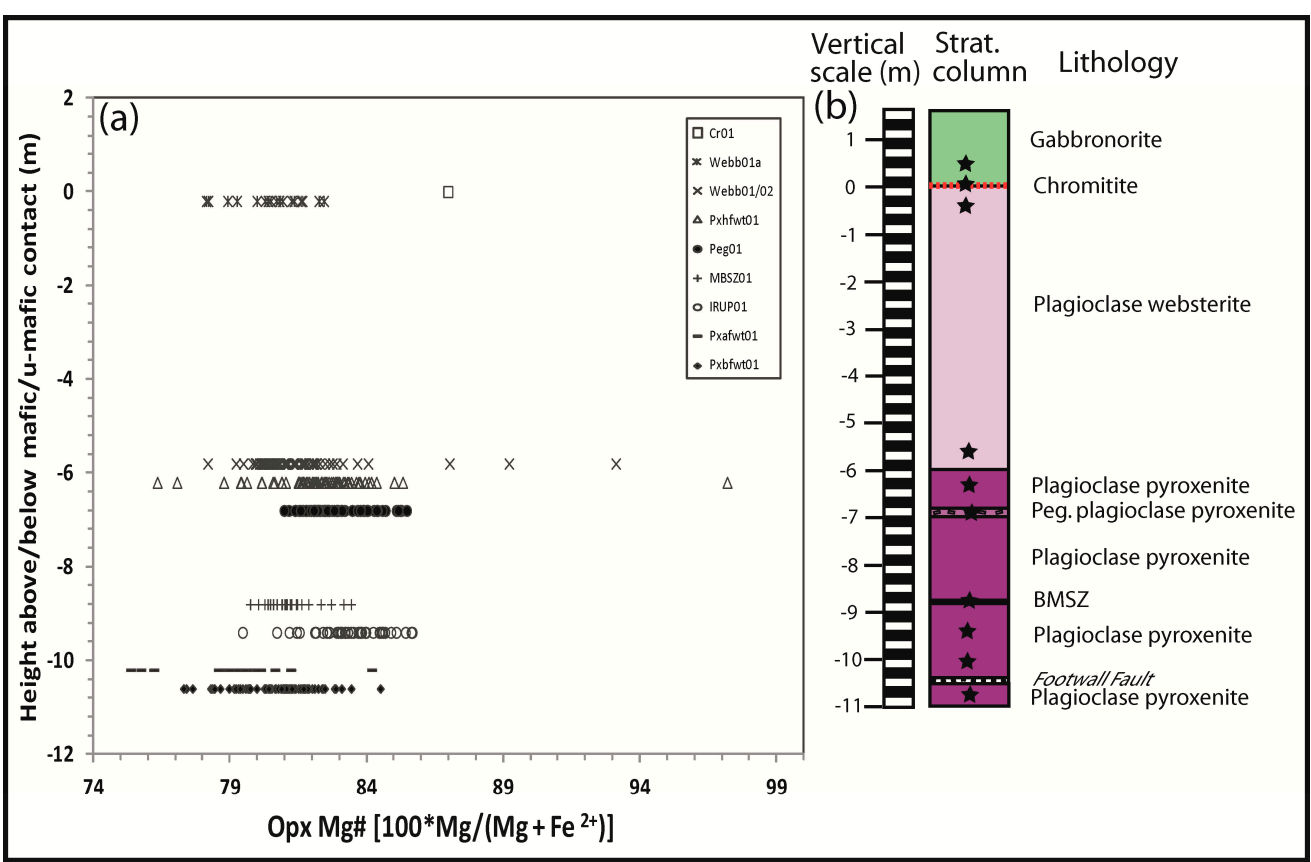

Figure 10. (a) Plot of orthopyroxene Mg\#s versus stratigraphic height of the MSZ for all orthopyroxene analyses. Corresponding sample locations and lithologies are shown in (b).

A total of 285 clinopyroxene analyses were performed for this study, and representative analyses are shown in Table 4 and all clinopyroxene analyses are listed in Supplementary Materials. Clinopyroxene Mg\#s range from a low of 80.7 in plagioclase websterite (sample MusWebb01/02) to a high of 99.7 in the same sample (Figure 13a,b). Across the MSZ, average clinopyroxene Mg\#s also show a spiked pattern, with the highest value occurring in plagioclase pyroxenite (sample IRUP01) just above the footwall to the MSZ (Figure 11a,b). The lowest clinopyroxene Mg\# value of 84.3 occurs in the base metal sulfide zone (sample MusBMSZ01) sample just above the one with the highest value, and the chromitite stringer also has a relatively high Mg\# value (75.5) than samples occurring below and above it (Figure 11a,b). Clinopyroxenes from the investigated section range in composition from 
pigeonites through augites to diopsides (Figure 12a) and a few of the samples tend to have $>50 \%$ Wo contents.

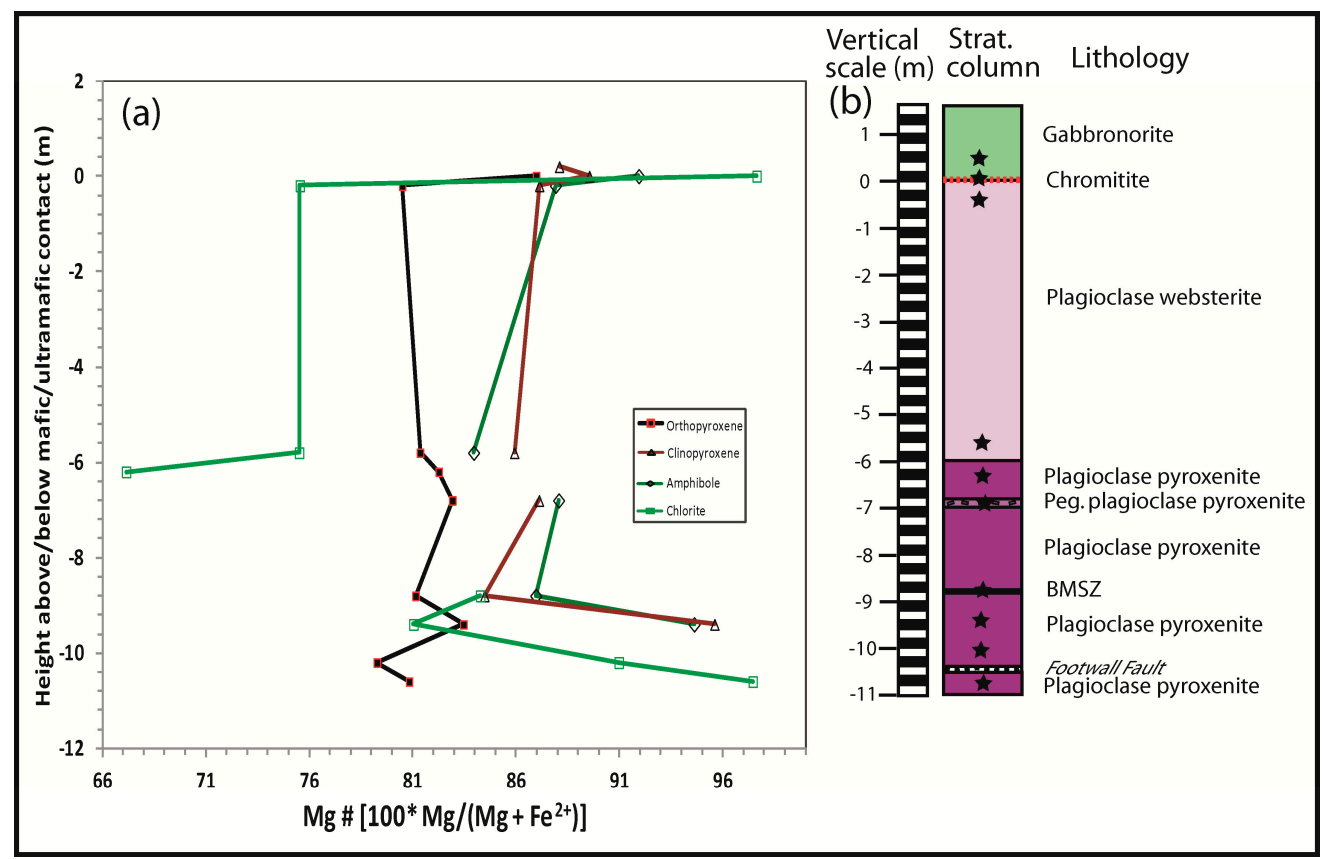

Figure 11. (a) Plot of Mg\#s of orthopyroxene, amphibole, clinopyroxene, and chlorite versus stratigraphic height of the MSZ. Corresponding sample locations and lithologies are shown in (b). 


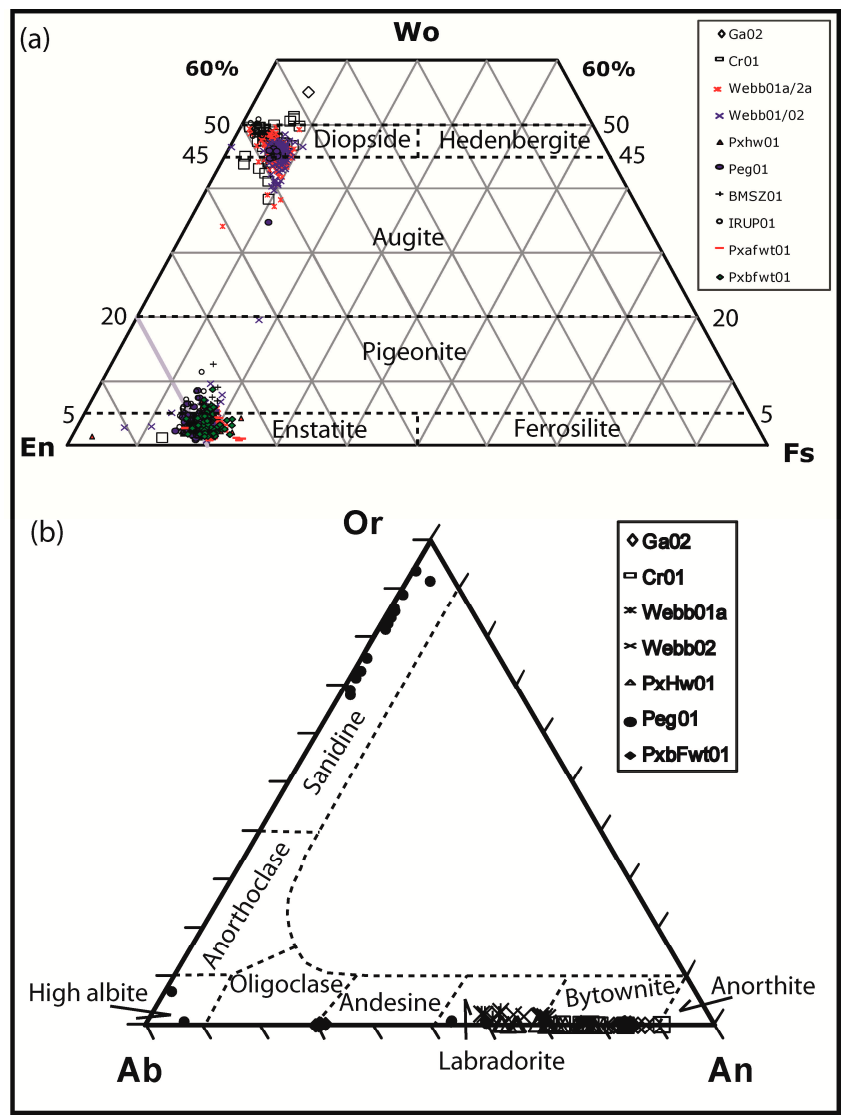

Figure 12. (a) Composition of both orthopyroxenes and clinopyroxenes from the MSZ which fall into the enstatite, pigeonite, augite and diopside fields. Classification of pyroxenes after Deer et al. (1992) [67]. (b) Composition of both plagioclase and potassium feldspars from the MSZ. 
Table 4. Representative clinopyroxene analyses in wt \%.

\begin{tabular}{|c|c|c|c|c|c|c|c|}
\hline Point & 10 & 4 & 5 & 10 & 1 & 99 & 89 \\
\hline Comment & $\begin{array}{l}\text { GA02 } \\
\text { P10 }\end{array}$ & $\begin{array}{l}\text { CR01 } \\
\text { P4 }\end{array}$ & $\begin{array}{l}\text { CR01 } \\
\text { P5 }\end{array}$ & $\begin{array}{l}\text { Webb01a } \\
\text { P10 }\end{array}$ & $\begin{array}{c}\text { Webb02a } \\
\text { P1 }\end{array}$ & $\begin{array}{c}\text { Webb02a } \\
\text { P99 }\end{array}$ & $\begin{array}{c}\text { Peg01 } \\
\text { P90 }\end{array}$ \\
\hline Depth (m) & 0.2 & 0 & 0 & -0.2 & -0.2 & -0.2 & -6.8 \\
\hline $\mathrm{SiO}_{2}$ & 54.33 & 52.69 & 52.45 & 52.37 & 51.93 & 52.19 & 52.32 \\
\hline $\mathrm{TiO}_{2}$ & 0.46 & 0.25 & 0.25 & 0.37 & 0.30 & 0.35 & 0.45 \\
\hline $\mathrm{Al}_{2} \mathrm{O}_{3}$ & 1.60 & 2.40 & 2.53 & 1.82 & 2.25 & 3.06 & 2.28 \\
\hline $\mathrm{Cr}_{2} \mathrm{O}_{3}$ & 0.30 & 0.92 & 1.25 & 0.46 & 0.61 & 0.71 & 0.83 \\
\hline $\mathrm{FeO}$ & 5.05 & 3.68 & 4.10 & 4.74 & 6.03 & 5.24 & 4.43 \\
\hline $\mathrm{MnO}$ & 0.21 & 0.12 & 0.12 & 0.10 & 0.16 & 0.16 & 0.15 \\
\hline $\mathrm{MgO}$ & 15.85 & 16.62 & 16.18 & 16.12 & 16.36 & 15.94 & 16.23 \\
\hline $\mathrm{CaO}$ & 22.13 & 22.19 & 22.44 & 23.01 & 21.79 & 21.90 & 22.09 \\
\hline $\mathrm{Na}_{2} \mathrm{O}$ & 0.20 & 0.24 & 0.24 & 0.25 & 0.34 & 0.36 & 0.37 \\
\hline Total & 100.16 & 99.14 & 99.57 & 99.25 & 99.78 & 99.92 & 99.15 \\
\hline \multicolumn{8}{|c|}{ Cations based on 6 oxygens } \\
\hline $\mathrm{Si}$ & 1.995 & 1.940 & 1.929 & 1.933 & 1.908 & 1.914 & 1.930 \\
\hline $\mathrm{Ti}$ & 0.013 & 0.007 & 0.007 & 0.010 & 0.008 & 0.010 & 0.012 \\
\hline $\mathrm{Al}$ & 0.069 & 0.104 & 0.110 & 0.079 & 0.098 & 0.132 & 0.099 \\
\hline $\mathrm{Cr}$ & 0.009 & 0.027 & 0.036 & 0.013 & 0.018 & 0.020 & 0.024 \\
\hline $\mathrm{Fe}^{3+}$ & 0.000 & 0.000 & 0.000 & 0.039 & 0.077 & 0.026 & 0.018 \\
\hline $\mathrm{Fe}^{2+}$ & 0.155 & 0.113 & 0.126 & 0.108 & 0.109 & 0.135 & 0.118 \\
\hline $\mathrm{Mn}$ & 0.006 & 0.004 & 0.004 & 0.003 & 0.005 & 0.005 & 0.005 \\
\hline $\mathrm{Mg}$ & 0.868 & 0.912 & 0.887 & 0.887 & 0.896 & 0.871 & 0.893 \\
\hline $\mathrm{Ca}$ & 0.871 & 0.875 & 0.884 & 0.910 & 0.858 & 0.861 & 0.873 \\
\hline $\mathrm{Na}$ & 0.014 & 0.017 & 0.017 & 0.018 & 0.024 & 0.026 & 0.027 \\
\hline Total & 4.000 & 4.000 & 4.000 & 4.000 & 4.000 & 4.000 & 4.000 \\
\hline En & 45.82 & 47.99 & 46.76 & 45.65 & 46.21 & 46.04 & 46.91 \\
\hline Fs & 8.19 & 5.96 & 6.64 & 7.53 & 9.55 & 8.49 & 7.19 \\
\hline Wo & 45.98 & 46.05 & 46.60 & 46.82 & 44.23 & 45.47 & 45.90 \\
\hline $\mathrm{Mg \#}$ & 84.83 & 88.95 & 87.56 & 89.18 & 89.19 & 86.59 & 88.29 \\
\hline
\end{tabular}

Bdl—below detection limit.

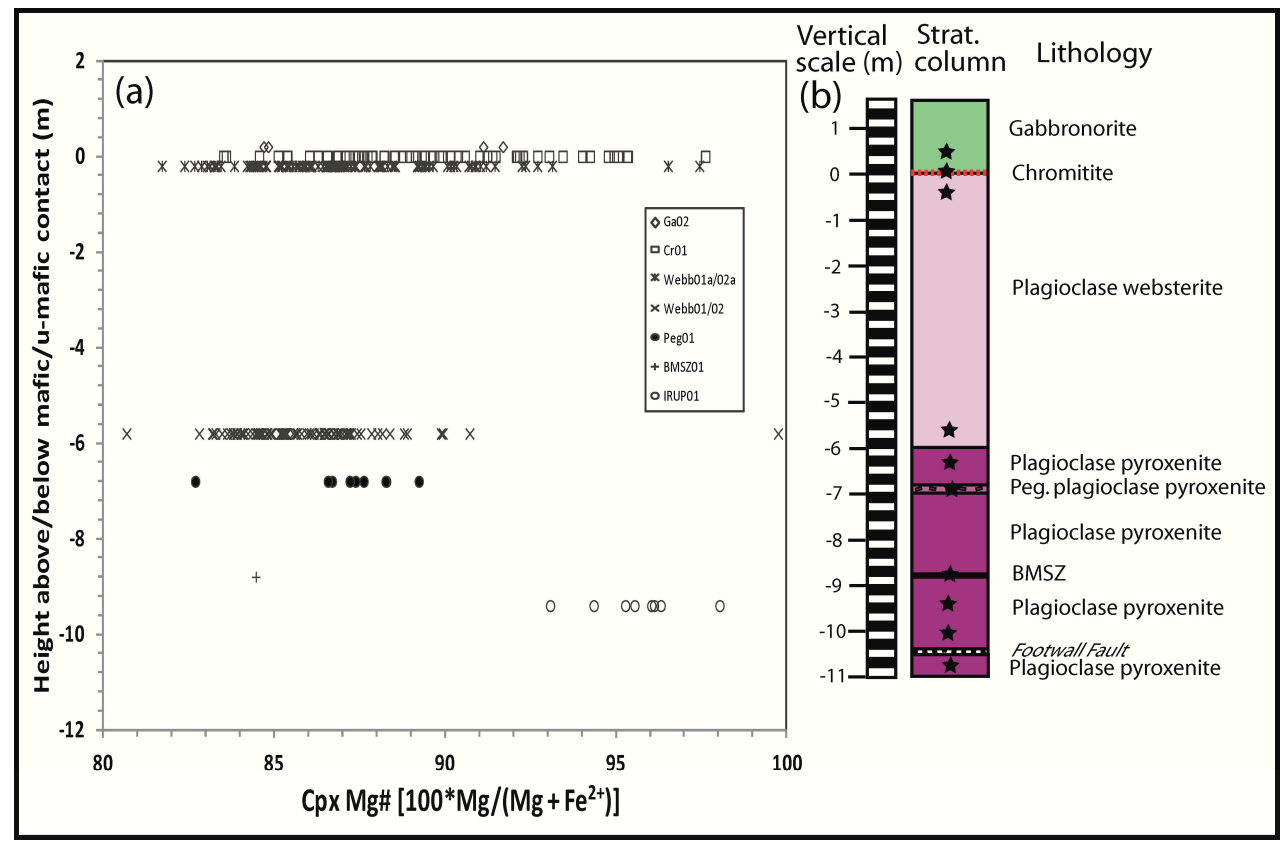

Figure 13. (a) Plot of clinopyroxene Mg\#s versus stratigraphic height of the MSZ for all clinopyroxene analyses. Corresponding sample locations and lithologies are shown in (b). 
Feldspar, which typically occurs either as an interstitial phase or as very coarse-grained (>5 mm in size) oikocrysts (pegmatoidal) in pyroxenitic rocks, is a cumulus phase only in the Mafic Sequence. 110 feldspar analyses were also obtained for this study, and representative results are shown in Table 5. The majority of the samples from the present study contain plagioclase feldspar with only alkali feldspars (sanidine) observed in the pegmatoidal plagioclase pyroxenite (Table 5; Supplementary Materials; Figure 12b). The sanidine has a composition of $\mathrm{Ab}_{30.6-5.8} \mathrm{Or}_{69.4-94.2}$, whereas plagioclase has a composition ranging from a low of $\mathrm{An}_{6.2}$ in the pegmatitic plagioclase pyroxenite (sample MusPeg01) to a high of $\mathrm{An}_{90.4}$ in the chromitite stringer (sample MusCr01) (Figures 12b and 14a,b). The majority of plagioclase feldspars from the gabbronorites, chromitite stringer, and plagioclase pyroxenites are bytownites and labradorites, with a few samples (all from the footwall to the MSZ-sample MusPxbFwt01) plotting in the andesine range (Figure 12b).

Table 5. Representative feldspar analyses in wt \%.

\begin{tabular}{|c|c|c|c|c|c|c|c|c|}
\hline Point & 3 & 18 & 16 & 110 & 121 & 30 & 44 & 92 \\
\hline \multirow{2}{*}{ Sample } & GA02 & GA02 & CR01 & Webb01a & Webb02 & PXHFW01 & Peg01 & PXBFWT01 \\
\hline & P3 & P18 & P16 & P110 & P121 & P30 & P44 & P92 \\
\hline $\mathrm{SiO}_{2}$ & 44.971 & 45.07 & 46.649 & 53.405 & 51.174 & 50.801 & 64.275 & 57.793 \\
\hline $\mathrm{TiO}_{2}$ & bdl & bdl & bdl & 0.031 & bdl & 0.077 & 0.073 & 0.025 \\
\hline $\mathrm{Al}_{2} \mathrm{O}_{3}$ & 34.137 & 35.795 & 33.171 & 28.26 & 30.195 & 29.194 & 18.026 & 24.372 \\
\hline $\mathrm{Cr}_{2} \mathrm{O}_{3}$ & bdl & bdl & 0.02 & 0.027 & bdl & 0.132 & bdl & 0.046 \\
\hline $\mathrm{FeO}$ & 0.522 & 0.387 & 0.449 & 0.373 & 0.402 & 0.536 & 0.101 & 0.264 \\
\hline $\mathrm{MnO}$ & bdl & bdl & 0.023 & 0.023 & 0.023 & 0.028 & 0.037 & 0.019 \\
\hline $\mathrm{MgO}$ & 0.007 & 0.057 & 0.101 & 0.022 & 0.063 & 0.087 & 0.015 & 0.045 \\
\hline $\mathrm{CaO}$ & 18.082 & 16.315 & 17.153 & 11.68 & 13.376 & 12.864 & 0.129 & 6.239 \\
\hline $\mathrm{BaO}$ & 0.048 & 0.097 & 0.035 & bdl & bdl & 0.214 & 0.025 & 0.433 \\
\hline $\mathrm{Na}_{2} \mathrm{O}$ & 1.201 & 1.881 & 1.775 & 4.462 & 3.702 & 3.897 & 1.151 & 7.513 \\
\hline $\mathrm{K}_{2} \mathrm{O}$ & 0.004 & 0 & 0 & 0.405 & 0.322 & 0.072 & 14.857 & 0.051 \\
\hline Total & 98.972 & 99.602 & 99.376 & 98.688 & 99.257 & 97.902 & 98.689 & 96.8 \\
\hline \multicolumn{9}{|c|}{ Cations based on 8 oxygens } \\
\hline $\mathrm{Si}$ & 2.094 & 2.071 & 2.157 & 2.454 & 2.345 & 2.363 & 3.002 & 2.667 \\
\hline $\mathrm{Ti}$ & 0.000 & 0.000 & 0.000 & 0.001 & 0.000 & 0.003 & 0.003 & 0.001 \\
\hline $\mathrm{Al}$ & 1.873 & 1.938 & 1.808 & 1.531 & 1.630 & 1.601 & 0.992 & 1.325 \\
\hline $\mathrm{Cr}$ & 0.000 & 0.000 & 0.001 & 0.001 & 0.000 & 0.005 & 0.000 & 0.002 \\
\hline $\mathrm{Fe}^{3+}$ & 0.000 & 0.000 & 0.000 & 0.000 & 0.000 & 0.000 & 0.000 & 0.000 \\
\hline $\mathrm{Fe}^{2+}$ & 0.020 & 0.015 & 0.017 & 0.014 & 0.015 & 0.021 & 0.004 & 0.010 \\
\hline $\mathrm{Mn}$ & 0.000 & 0.000 & 0.001 & 0.001 & 0.001 & 0.001 & 0.001 & 0.001 \\
\hline $\mathrm{Mg}$ & 0.000 & 0.004 & 0.007 & 0.002 & 0.004 & 0.006 & 0.001 & 0.003 \\
\hline $\mathrm{Ca}$ & 0.902 & 0.803 & 0.850 & 0.575 & 0.657 & 0.641 & 0.006 & 0.308 \\
\hline $\mathrm{Ba}$ & 0.001 & 0.002 & 0.001 & 0.000 & 0.000 & 0.004 & 0.000 & 0.008 \\
\hline $\mathrm{Na}$ & 0.108 & 0.168 & 0.159 & 0.398 & 0.329 & 0.351 & 0.104 & 0.672 \\
\hline \multirow[t]{2}{*}{$\mathrm{K}$} & 0.000 & 0.000 & 0.000 & 0.024 & 0.019 & 0.004 & 0.885 & 0.003 \\
\hline & 5.000 & 5.000 & 5.000 & 5.000 & 5.000 & 5.000 & 5.000 & 5.000 \\
\hline An & 89.25 & 82.74 & 84.23 & 57.72 & 65.38 & 64.31 & 0.65 & 31.36 \\
\hline $\mathrm{Ab}$ & 10.73 & 17.26 & 15.77 & 39.90 & 32.75 & 35.26 & 10.47 & 68.34 \\
\hline Or & 0.02 & 0.00 & 0.00 & 2.38 & 1.87 & 0.43 & 88.89 & 0.31 \\
\hline
\end{tabular}

Bdl-below detection limit.

Amphibole is the dominant and more widespread hydrous mineral than chlorite across the MSZ at Unki Mine. A total of 253 amphibole analyses were performed (Table 6; Supplementary Materials), with 143 of these being Fe-Mg-Mn amphiboles (Figure 15a) whereas 110 of them are calcic amphiboles (Figure 15b). Anthophyllite is the dominant Fe-Mg-Mn amphibole type encountered in the MSZ at Unki Mine followed by gedrites (Figure 15a). Calcic amphiboles occurring in the MSZ at Unki Mine are dominated by tremolite, magnesiohornblende, and actinolite, with only a single sample plotting in the tschermakite field (Figure 15b). Across the MSZ, amphibole Mg\#s range from a high of 95.6 within the plagioclase pyroxenite at the base of the mineralized zone just above the footwall to a low of 84.0 near the bottom of the plagioclase pyroxenite (sample MusWebb01/02) (Figure 11). The amphibole Mg\# also shows a spiked pattern that mimics those of both orthopyroxene and clinopyroxene (Figure 11). 


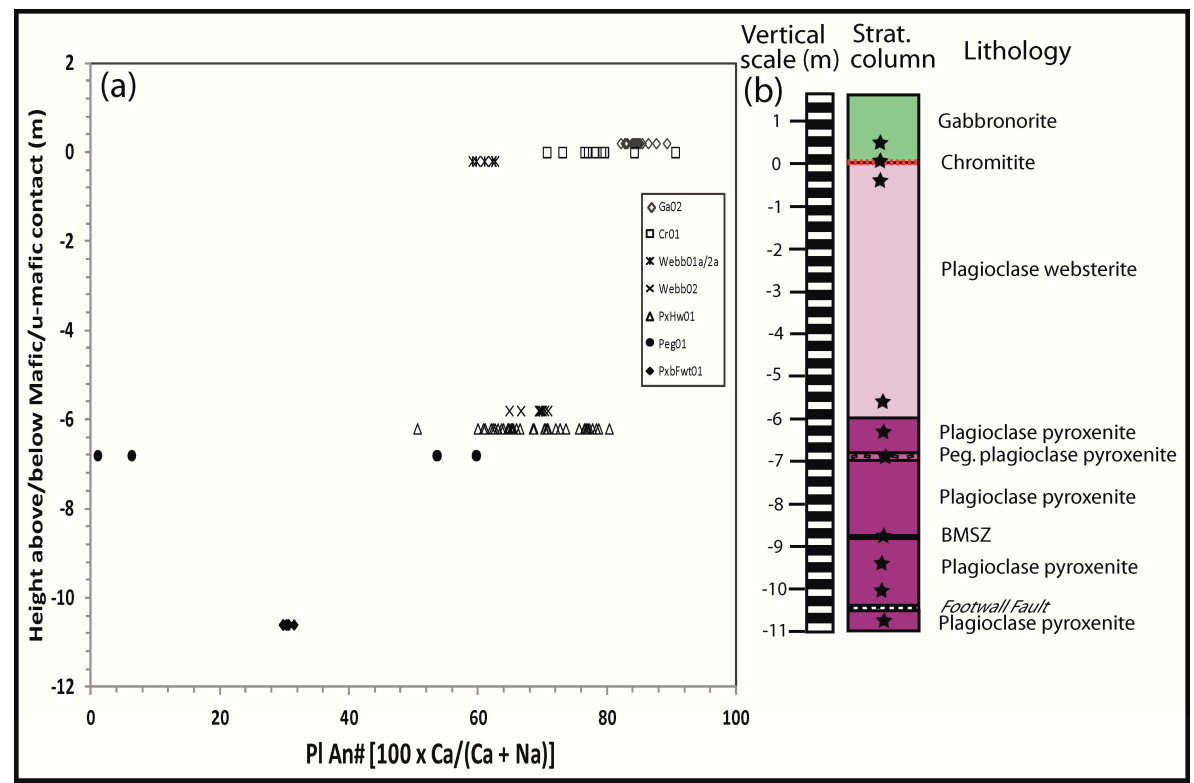

Figure 14. (a) Plot of plagioclase An\#s versus stratigraphic height of the MSZ for all plagioclase analyses. Corresponding sample locations and lithologies are shown in (b).

Table 6. Representative amphibole analyses in wt \%.

\begin{tabular}{|c|c|c|c|c|c|c|c|c|}
\hline \multicolumn{5}{|c|}{ Fe-Mg-Mn Amphiboles } & \multicolumn{4}{|c|}{ Calcic Amphiboles } \\
\hline Point & 43 & 45 & 28 & 118 & 57 & 60 & 61 & 102 \\
\hline \multirow{2}{*}{ Sample } & Webb01a & Webb01a & Webb01a & Peg01 & CR01 & CR01 & CR01 & Webb01a \\
\hline & $\mathrm{P} 43$ & $\mathrm{P} 45$ & $\mathrm{P} 28$ & P119 & P57 & P60 & P61 & P102 \\
\hline Depth (m) & -0.2 & -0.2 & -0.2 & -6.8 & 0 & 0 & 0 & -0.2 \\
\hline $\mathrm{SiO}_{2}$ & 57.02 & 53.53 & 53.69 & 54.36 & 53.05 & 53.91 & 56.39 & 52.52 \\
\hline $\mathrm{TiO}_{2}$ & 0.11 & 0.19 & 0.12 & 0.17 & 0.22 & 0.25 & 0.16 & 0.19 \\
\hline $\mathrm{Al}_{2} \mathrm{O}_{3}$ & 1.58 & 1.29 & 1.34 & 0.77 & 2.92 & 2.53 & 1.21 & 1.69 \\
\hline $\mathrm{FeO}$ & 5.59 & 13.38 & 12.78 & 11.29 & 7.31 & 2.29 & 2.14 & 8.23 \\
\hline $\mathrm{MnO}$ & bdl & 0.34 & 0.30 & 0.22 & 0.19 & 0.02 & bdl & 0.24 \\
\hline $\mathrm{MgO}$ & 27.88 & 26.94 & 28.07 & 29.47 & 18.23 & 20.22 & 22.32 & 17.19 \\
\hline $\mathrm{CaO}$ & 0.12 & 1.92 & 1.63 & 0.90 & 12.31 & 16.82 & 13.04 & 14.69 \\
\hline $\mathrm{Na}_{2} \mathrm{O}$ & 0.30 & 0.01 & 0.03 & 0.02 & 0.39 & 0.28 & 0.12 & 0.20 \\
\hline $\mathrm{K}_{2} \mathrm{O}$ & 0.02 & bdl & 0.01 & 0.01 & bdl & 0.01 & bdl & bdl \\
\hline $\mathrm{BaO}$ & bdl & bdl & bdl & bdl & 0.04 & bdl & bdl & bdl \\
\hline $\mathrm{Cr}_{2} \mathrm{O}_{3}$ & 0.30 & 0.29 & 0.37 & 0.20 & 0.72 & 0.80 & 0.43 & 0.40 \\
\hline Total & 92.92 & 97.89 & 98.32 & 97.41 & 95.37 & 97.14 & 95.81 & 95.35 \\
\hline \multicolumn{9}{|c|}{ Cations based on 23 oxygens } \\
\hline $\mathrm{Si}$ & 7.995 & 7.358 & 7.309 & 7.408 & 7.606 & 7.560 & 7.854 & 7.673 \\
\hline $\mathrm{Al}^{\mathrm{iv}}$ & 0.005 & 0.209 & 0.215 & 0.124 & 0.394 & 0.418 & 0.146 & 0.292 \\
\hline $\mathrm{Al}^{\mathrm{vi}}$ & 0.257 & 0.000 & 0.000 & 0.000 & 0.100 & 0.000 & 0.053 & 0.000 \\
\hline $\mathrm{Ti}$ & 0.012 & 0.020 & 0.012 & 0.017 & 0.024 & 0.026 & 0.017 & 0.021 \\
\hline $\mathrm{Cr}$ & 0.033 & 0.031 & 0.039 & 0.022 & 0.082 & 0.089 & 0.047 & 0.046 \\
\hline $\mathrm{Fe}^{3+}$ & 0.000 & 1.002 & 1.095 & 0.996 & 0.271 & 0.000 & 0.090 & 0.000 \\
\hline $\mathrm{Fe}^{2+}$ & 0.656 & 0.535 & 0.360 & 0.290 & 0.605 & 0.269 & 0.160 & 1.005 \\
\hline $\mathrm{Mn}$ & 0.000 & 0.040 & 0.035 & 0.026 & 0.023 & 0.003 & 0.000 & 0.029 \\
\hline $\mathrm{Mg}$ & 5.828 & 5.521 & 5.698 & 5.987 & 3.895 & 4.228 & 4.634 & 3.743 \\
\hline $\mathrm{Ca}$ & 0.018 & 0.283 & 0.237 & 0.131 & 1.891 & 2.527 & 1.945 & 2.299 \\
\hline $\mathrm{Na}$ & 0.082 & 0.002 & 0.007 & 0.006 & 0.108 & 0.076 & 0.031 & 0.056 \\
\hline $\mathrm{K}$ & 0.003 & 0.000 & 0.001 & 0.002 & 0.000 & 0.002 & 0.000 & 0.000 \\
\hline $\mathrm{Ba}$ & 0.000 & 0.000 & 0.000 & 0.000 & 0.002 & 0.000 & 0.000 & 0.000 \\
\hline Total & 14.888 & 15.002 & 15.009 & 15.008 & 15.001 & 15.199 & 14.977 & 15.165 \\
\hline$(\mathrm{Ca}+\mathrm{Na})(\mathrm{B})$ & 0.100 & 0.283 & 0.237 & 0.131 & 1.999 & 2.527 & 1.977 & 2.299 \\
\hline $\mathrm{Na}(\mathrm{B})$ & 0.082 & 0.000 & 0.000 & 0.000 & 0.108 & 0.000 & 0.031 & 0.000 \\
\hline$(\mathrm{Na}+\mathrm{K})(\mathrm{A})$ & 0.003 & 0.002 & 0.009 & 0.008 & 0.000 & 0.078 & 0.000 & 0.056 \\
\hline $\mathrm{Mg} /\left(\mathrm{Mg}+\mathrm{Fe}^{2+}\right)$ & 0.899 & 0.912 & 0.941 & 0.954 & 0.866 & 0.940 & 0.967 & 0.788 \\
\hline $\begin{array}{c}\text { Amphibole } \\
\text { names }\end{array}$ & anthophyllite & $\begin{array}{c}\text { magnesio- } \\
\text { anthophyllite }\end{array}$ & $\begin{array}{l}\text { magnesio- } \\
\text { anthophyllite }\end{array}$ & $\begin{array}{l}\text { magnesio- } \\
\text { anthophyllite }\end{array}$ & actinolite & tremolite & tremolite & actinolite \\
\hline
\end{tabular}



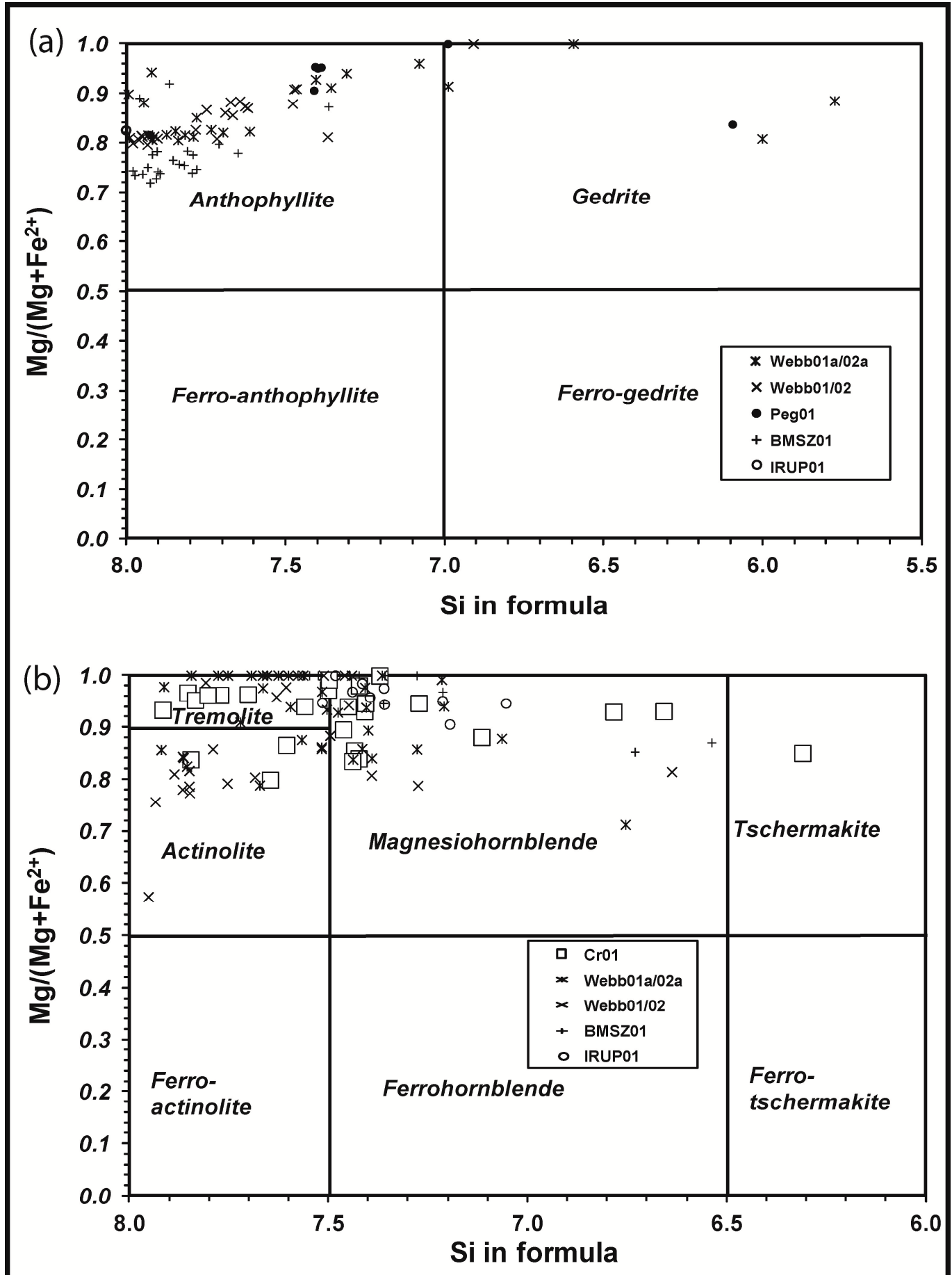

Figure 15. (a) Plot of amphibole analyses from MSZ on the Fe-Mg-Mn (a), and calcic amphibole (b), classification diagrams of Leake et al. (1997) [68]. All Fe-Mg-Mn amphiboles plot in the anthophyllite and gedrite fields (a) whereas calcic amphiboles mostly plot in the tremolite, actinolite, and magnesiohornblende fields (b). 
Only 62 chlorite analyses were obtained from the suite of samples studied (Table 7; Supplementary Materials). Chlorite compositions range from 5.946 to $7.931 \mathrm{Si}$ atoms per formula unit (apfu) and from 1.085 to $3.430 \mathrm{apfu}$, and they plot in the pycnochlorite, clinochlore, diabantite, penninite, and talc-chlorite fields (Figure 16a). On an $\mathrm{Al}, \mathrm{Fe}$, and $\mathrm{Mg}$ ternary diagram, all the chlorites from the MSZ at Unki Mine plot in the Type I chlorites (Figure 16b). From the bottom of the investigated section upwards, chlorite Mg\#s show a decrease from the second highest value of 97.4 occurring in the plagioclase pyroxenite forming the footwall of the MSZ (sample MusPxbFwt01) to a value of 81.0 (sample MusIRUP01) and then increase again to a value of 84.3 at the base metal sulfide zone (sample BMSZ01) (Figure 11a). No chlorite was observed in the pegmatoidal plagioclase pyroxenite (Figure 11a,b). The lowest chlorite Mg\# value of 67.1 occurs in the topmost plagioclase pyroxenite (sample MusPxHw01) and then increases to the highest chlorite Mg\# of 97.6 observed which occurs in the chromitite stringer at the contact of the Ultramafic and Mafic Sequences (sample MusCr01) (Figure 11a,b). Minute crystals of quartz were also encountered in the present investigation.

Table 7. Representative chlorite analyses in wt \%.

\begin{tabular}{|c|c|c|c|c|c|c|c|}
\hline Point & Chl 77 & 77 & 105 & 120 & 67 & Chl 7 & Chl 52 \\
\hline Sample & $\begin{array}{l}\text { CR01 } \\
\text { P77 }\end{array}$ & $\begin{array}{l}\text { Webb01a } \\
\text { P77 }\end{array}$ & $\begin{array}{l}\text { Webb01a } \\
\text { P105 }\end{array}$ & $\begin{array}{c}\text { Webb01 } \\
\text { P120 }\end{array}$ & $\begin{array}{c}\text { Webb02 } \\
\text { P67 }\end{array}$ & $\begin{array}{l}\text { BMSZ01 } \\
\text { P7 }\end{array}$ & $\begin{array}{l}\text { IRUP01 } \\
\text { P52 }\end{array}$ \\
\hline $\mathrm{SiO}_{2}$ & 42.663 & 38.729 & 29.4 & 33.619 & 30.955 & 36.214 & 41.292 \\
\hline $\mathrm{TiO}_{2}$ & 0.053 & 0.266 & 0.05 & bdl & 0.09 & 0.183 & 0.301 \\
\hline $\mathrm{Al}_{2} \mathrm{O}_{3}$ & 8.273 & 12.313 & 17.72 & 11.056 & 15.795 & 12.267 & 10.807 \\
\hline $\mathrm{FeO}$ & 7.991 & 10.732 & 16.04 & 17.385 & 15.501 & 10.575 & 15.548 \\
\hline $\mathrm{MnO}$ & 0.102 & 0.041 & 0.2 & 0.195 & 0.146 & 0.064 & 0.106 \\
\hline $\mathrm{MgO}$ & 26.193 & 22.357 & 21.458 & 23.58 & 23.101 & 25.84 & 17.519 \\
\hline $\mathrm{CaO}$ & 0.31 & 0.554 & 0.078 & 0.202 & 0.09 & 0.204 & 0.794 \\
\hline $\mathrm{Na}_{2} \mathrm{O}$ & 0.093 & 0.337 & 0.04 & 0.011 & 0.009 & 0.154 & 0.092 \\
\hline $\mathrm{K}_{2} \mathrm{O}$ & 0.029 & 1.587 & 0.443 & 0.009 & bdl & 0.489 & 0.009 \\
\hline $\mathrm{BaO}$ & 0.011 & 0.014 & bdl & 0.007 & bdl & bdl & 0.264 \\
\hline $\mathrm{Cr}_{2} \mathrm{O}_{3}$ & 1.132 & 0.038 & 0.037 & 0.337 & 0.019 & 0.257 & 0.422 \\
\hline Total & 86.85 & 86.968 & 85.466 & 86.401 & 85.706 & 86.247 & 87.154 \\
\hline \multicolumn{8}{|c|}{ Formula based on 36 oxygens } \\
\hline $\mathrm{Si}$ & 7.931 & 7.369 & 6.014 & 6.831 & 6.275 & 7.019 & 7.889 \\
\hline $\mathrm{Ti}$ & 0.007 & 0.038 & 0.008 & 0.000 & 0.014 & 0.027 & 0.043 \\
\hline $\mathrm{Al}$ & 1.813 & 2.762 & 4.273 & 2.648 & 3.774 & 2.802 & 2.434 \\
\hline $\mathrm{Cr}$ & 0.166 & 0.006 & 0.006 & 0.054 & 0.003 & 0.039 & 0.064 \\
\hline $\mathrm{Fe}^{3+}$ & 1.066 & 0.710 & 0.134 & 0.209 & 0.205 & 0.470 & 1.362 \\
\hline $\mathrm{Fe}^{2+}$ & 0.176 & 0.997 & 2.611 & 2.745 & 2.423 & 1.244 & 1.122 \\
\hline $\mathrm{Mn}$ & 0.016 & 0.007 & 0.035 & 0.034 & 0.025 & 0.011 & 0.017 \\
\hline $\mathrm{Mg}$ & 7.259 & 6.341 & 6.544 & 7.142 & 6.980 & 7.466 & 4.989 \\
\hline $\mathrm{Ca}$ & 0.062 & 0.113 & 0.017 & 0.044 & 0.020 & 0.042 & 0.163 \\
\hline $\mathrm{Na}$ & 0.067 & 0.249 & 0.032 & 0.009 & 0.007 & 0.116 & 0.068 \\
\hline $\mathrm{K}$ & 0.014 & 0.770 & 0.231 & 0.005 & 0.000 & 0.242 & 0.004 \\
\hline $\mathrm{Ba}$ & 0.002 & 0.002 & 0.000 & 0.001 & 0.000 & 0.000 & 0.040 \\
\hline Total & 18.580 & 19.364 & 19.903 & 19.721 & 19.725 & 19.478 & 18.194 \\
\hline $\mathrm{Fe}^{2+}+\mathrm{Fe}^{3+}$ & 1.232 & 1.707 & 2.745 & 2.954 & 2.628 & 1.714 & 2.484 \\
\hline Chlorite type & talc-chlorite & diabantite & pycnochlorite & diabantite & diabantite & talc-chlorite & diabantite \\
\hline
\end{tabular}




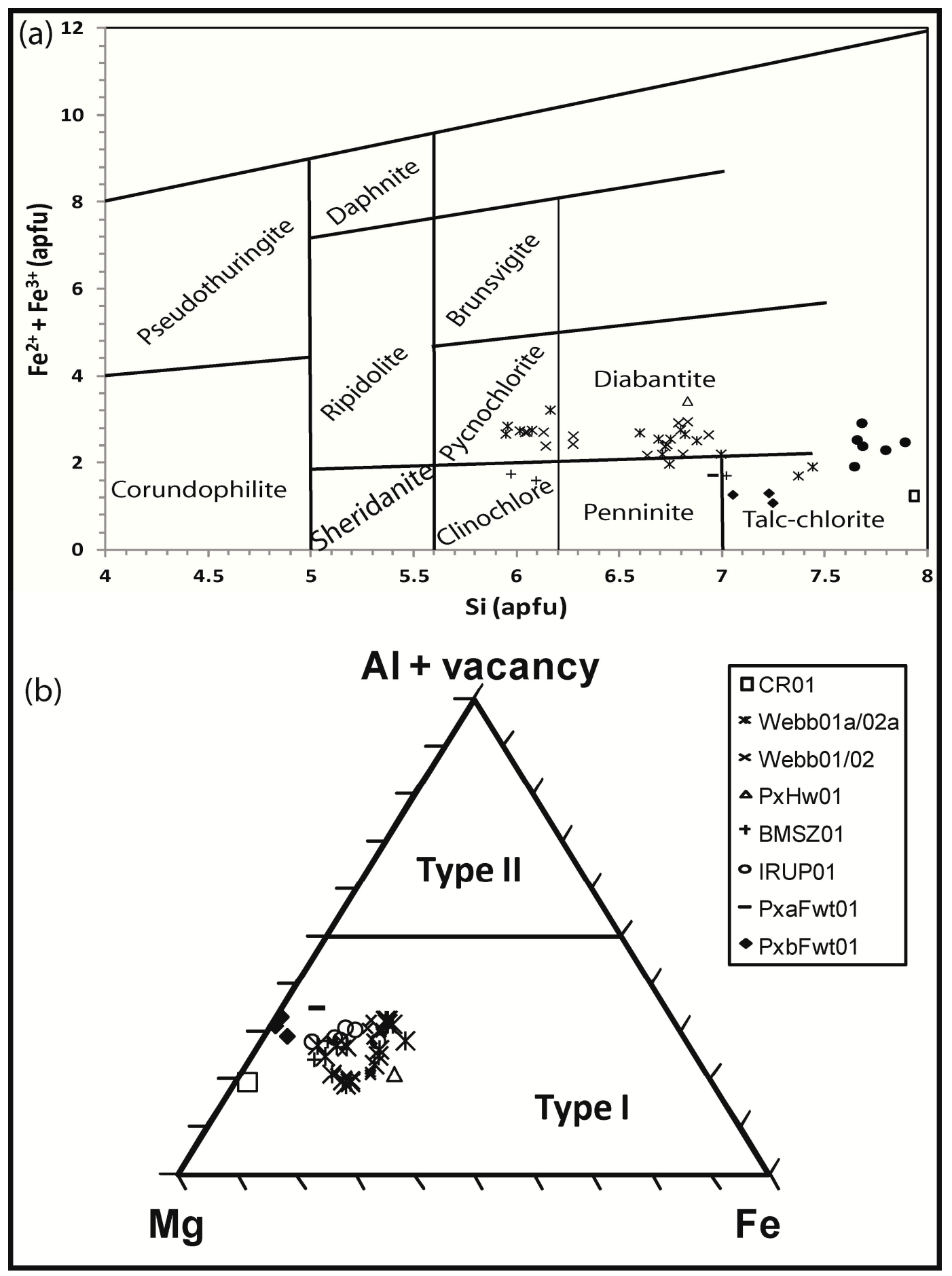

Figure 16. (a) Plot of chlorite analyses from the present study on a chlorite classification diagram of Hey (1954) [69]. Chlorite analyses from the MSZ plot in the pycnochlorite, clinochlore, diabantite, and talc-chlorite fields. (b) plot of chlorite analyses on at $\mathrm{Al}+$ vacancy, $\mathrm{Fe}$ and $\mathrm{Mg}$ ternary diagram (after Zane and Weiss, 1998 [70]) and all samples from the present study fall into Type I chlorites. 


\section{Discussion}

From petrographic descriptions provided, it is proposed that the paragenetic sequence for the MSZ at Unki Mine is orthopyroxene plagioclase $\rightarrow$ clinopyroxene $\rightarrow$ chromite $\rightarrow$ sulfides + PGEs $\rightarrow$ amphibole/chlorite/quartz, although the documented hydrothermal activity may complicate this sequence. The observations made of sulfides occurring in association within cumulus minerals such as plagioclase, clinopyroxene, and orthopyroxene as well as sulfides occurring in association with minerals like chlorite and amphibole which are interpreted to be hydrothermal alteration phases (e.g., Figures 8 and 9) point to two generations of sulfide mineralization at Unki Mine. The sulfides that were encountered during this investigation are pyrrhotite, chalcopyrite, pentlandite, and pyrite. Pyrite was only observed in the two topmost samples (MusCa02 and MusCr01), and it is inferred to be an alteration product of pyrrhotite as it has a tendency of occurring in association with the hydrothermal alteration phases of amphibole and chlorite.

All primary sulfide minerals of pyrrhotite, chalcopyrite, and pentlandite tend occur as inclusions in cumulate minerals and generally tend to be coarse-grained in comparison to sulfides which occur in association with alteration minerals. Some sulfides inferred to have been formed due to hydrothermal alteration activities, however, may also be coarse-grained, but these tend to occur only in association with chlorite and amphibole. Some primary sulfides also occur in association with hydrothermal minerals, suggesting that primary mineralization in the MSZ may have been subsequently enriched due to magmatic hydrothermal fluids. Hydrothermal alteration processes may also have led to the formation of pyrite. Sulfides occurring as inclusions in chromite and silicate crystals are interpreted to be primary and are not associated with any fractures [71], and were thus likely formed during the crystallization history of the intrusion. The relatively finer-grained sulfides, which have a tendency to occur in association with hydrothermal alteration phases of chlorite and amphibole and which are also associated with fractures and veinlets, were probably formed later during hydrothermal alteration. Further, the occurrence of fine-grained sulfides laths in association with hydrothermal alteration minerals like chlorite (e.g., Figure $8 \mathrm{f}$ ) lends support to these sulfides having been formed during hydrothermal processes. The fine laths appear to have the same orientation as that of the basal cleavage in the chlorite host, probably an indication that fluid flow may have been responsible for the precipitation of the sulfide laths during chlorite formation. Thus, remobilization of earlier formed magmatic mineralization by hydrothermal processes appears to have occurred within the MSZ at Unki Mine. The difference

The predominance of chlorite in the sample just above the footwall fault (PxaFwt01) may have been promoted by hydrothermal fluids which likely permeated through the fault helping form the chlorite crystals above this fault (Figure 9e) in particular, and possibly throughout the entire MSZ. In contradistinction, in the sample just below the footwall fault (MusPabFwt01), no evidence of hydrothermal processes is observed here unlike in the sample just above the footwall fault, since the footwall fault is located immediately above this sample (Figure 9f). The timing of this fault is not constrained at present; it may have been synchronous with magmatism and it was later re-activated.

Pyroxene compositions from the present study are broadly consistent with magmatic pyroxenes and are comparable to those from other layered intrusions elsewhere (Figure 17a). A few clinopyroxenes analyses, however, are diopsides enriched in calcium relative to most magmatic clinopyroxenes (Figure 17a). Magmatic clinopyroxenes have a tendency to be uniform in rock successions where no fresh batches of magma were injected into the magma chamber, but secondary clinopyroxenes such as diopsides form during hydrothermal alteration due to calcium enrichment of magmatic clinopyroxenes caused by the transfer of components through the hydrothermal fluid [72,73]. 


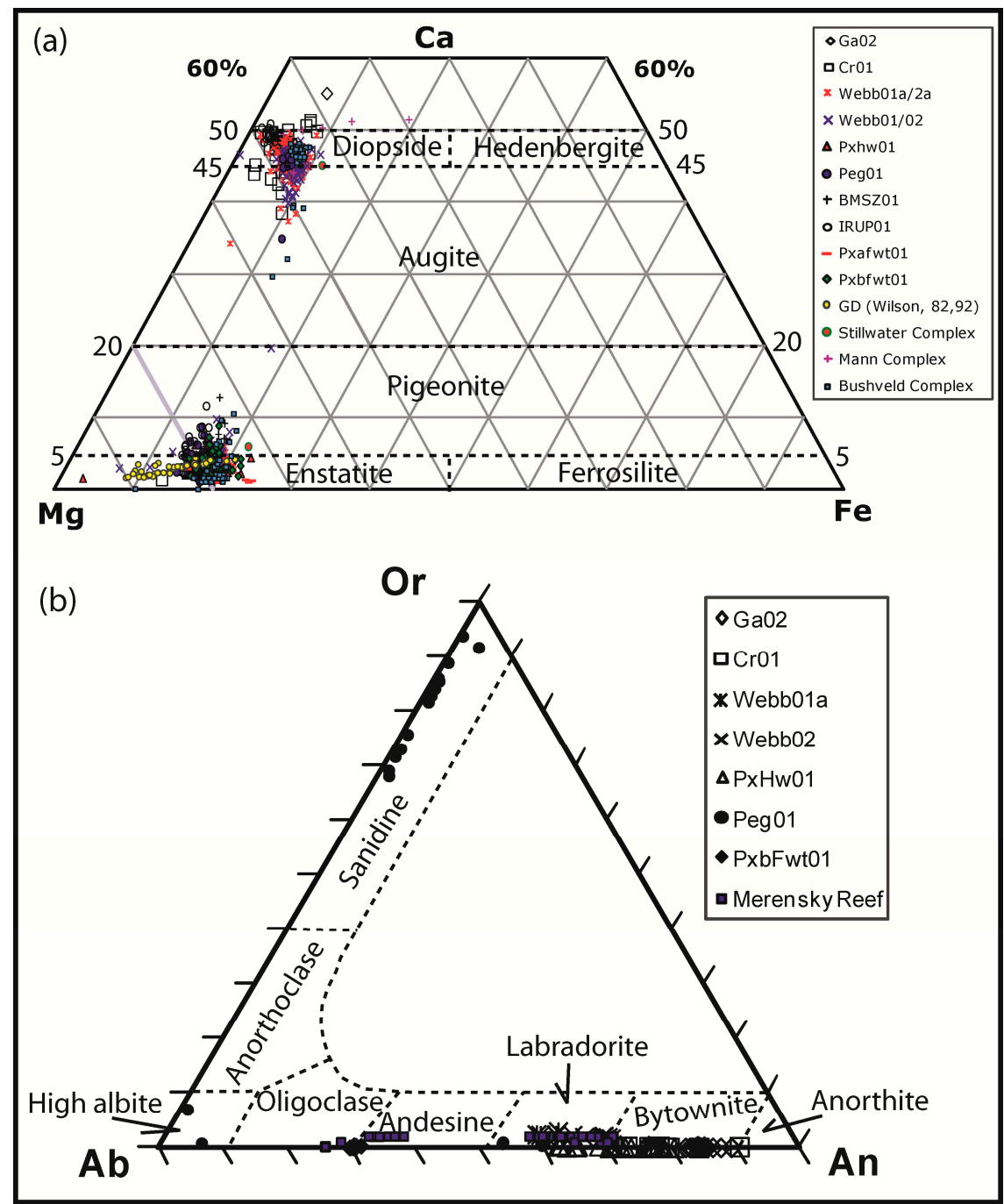

Figure 17. (a) Plot of pyroxenes from the present investigation compared to orthopyroxenes from the Great Dyke [32,74] and those from other intrusions. Data sources are: Merensky Reef of the Bushveld Complex [75,76], J-M Reef of the Stillwater Complex [10], and Mann Complex [73]. Note the highly calcic nature of some clinopyroxenes from the present study as well as those from the hydrothermally altered Mann Complex. (b) Plot of feldspars from the present investigation compared to those from the Merensky Reef of the Bushveld Complex $[75,76]$.

The majority of pyroxene analyses have totals that are less 100\% (Tables 3 and 4, Supplementary Materials), suggesting that these pyroxenes may contain small amounts of $\mathrm{H}_{2} \mathrm{O}$ or other volatiles as submicroscopic inclusions [77]. Further, the absence of non-quadrilateral components in diopside compared to igneous clinopyroxene, for example, has been interpreted to indicate formation of the diopside in a relatively lower-temperature hydrothermal environment of $>300{ }^{\circ} \mathrm{C}[72,78,79]$. The diopsides in this investigation are also characterized by low concentrations of non-quadrilateral components (Tables 3 and 4, Supplementary Materials). Great Dyke MSZ clinopyroxene samples are thus more magnesian than those from most other layered intrusions [32,80].

Feldspars similarly have totals that are less $100 \%$ (Table 5, Supplementary Materials), again suggesting that they may contain small amounts of $\mathrm{H}_{2} \mathrm{O}$ or other volatiles such as volatile submicroscopic inclusions [77]. Plagioclase analyses from the Merensky Reef of the Bushveld Complex mostly plot in the labradorite and andesine fields, with few analyses plotting in the bytownite and oligoclase fields (Figure 17b). Thus, just like pyroxene Mg\#s (e.g., Figure 17a; [81]), Merensky Reef 
plagioclase analyses are less calcic than those from the MSZ. Although some analyses for quartz crystals were obtained in this investigation, these were all much lower than 100, possibly due to interference from other minerals due to the very fine-grained nature of the quartz crystals.

The Pozanti-Karsanti ophiolite has amphiboles ranging in composition from magnesiohornblende to actinolite [82] (Figure 18a). The aluminous amphiboles are thought have formed during high pressure, high temperature hydrothermal alteration [82]. In this ophiolite, calcic amphiboles such as actinolite commonly occur rimming clinopyroxenes or high-Al and high-Fe hornblende [82]. Further, Stakes and Taylor (1992) [83] suggested that high-temperature metamorphic hornblendes in the Semail ophiolite of Oman (pargasites and edenites; [84]) were replaced by low-temperature actinolitic hornblendes due to the extensive moderate to low-temperature hydrothermal alteration.

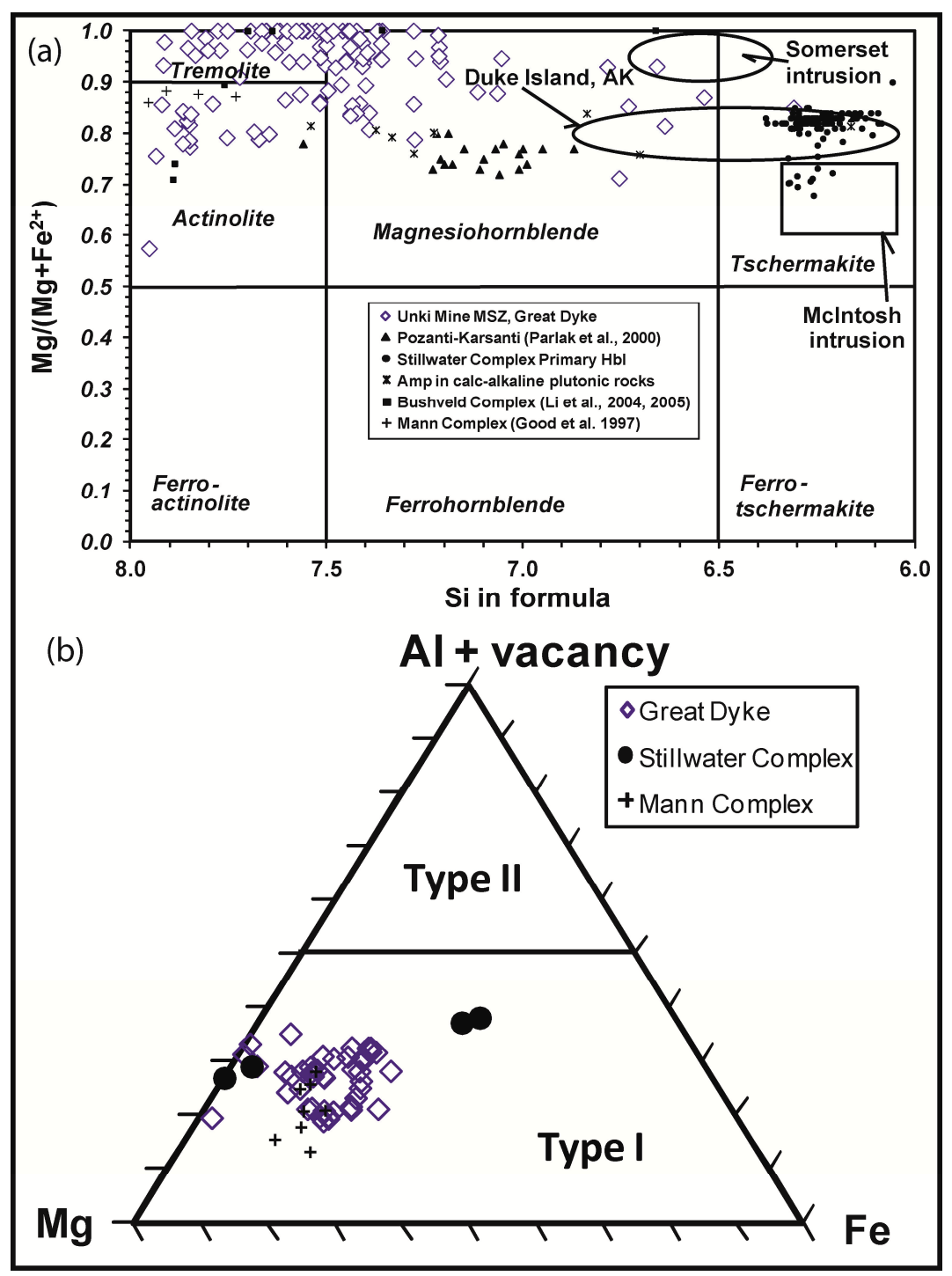

Figure 18. (a) Calcic amphiboles from the present study compared those from other intrusions and settings: Stillwater Complex primary hornblende [85], Merensky Reef of the Bushveld Complex [7,75], Mann Complex [73], Somerset intrusion [86], McIntosh intrusion [87], Duke Island complex, Alaska [88], and Pozanti-Karsanti ophiolite [82]. Unlike primary hornblende from the Stillwater Complex, calcic amphiboles from the MSZ at Unki Mine show a wide range in Si apfu consistent with hydrothermal alteration such as those in ophiolite complexes such as the Pozanti-Karsanti. (b) Chlorites from the present study compared to those from the J-M Reef of the Stillwater Complex [10] and the Mann Complex [73]. 
Unlike amphiboles from ophiolites, those from the present investigation do not show any zoning, suggesting that they were formed from replacement of orthopyroxenes during hydrothermal alteration [67]. Further, the observation that amphibole Mg\#s from the MSZ mimic those of both pyroxenes (Figure 11), lend support to the interpretation that Unki Mine MSZ amphiboles were derived from the alteration of pyroxenes in-situ and were not formed from cations and fluids derived from outside the intrusion. Magnesiohornblende and tschermakite are consistent with amphibolite facies hydrothermal alteration, whereas tremolite and actinolite are consistent with greenschist facies hydrothermal alteration. Hydrothermal alteration of orthopyroxenes formed Fe-Mg-Mn amphiboles whereas calcic amphiboles were formed from the hydrothermal alteration of clinopyroxenes [67]. An application of the Zane and Weiss (1998) [70] method of classifying chlorites based on microprobe analyses reveals that MSZ chlorites and chlorites from other intrusions such as the Stillwater Complex and the Mann Complex are Mg-rich Type I chlorites (Figure 18b), likely pointing to their derivation from hydrothermal alteration of magnesium-rich minerals such as pyroxenes. Chlorite occurring in igneous rocks such as those under investigation, and its association with BMS, lends support to a hydrothermal origin for some of the mineralization as chlorite in such rocks tends to be derived from hydrothermal alteration of primary ferromagnesian minerals [67] such as pyroxenes which form the dominant minerals in the Cyclic Unit 1 of the Great Dyke.

Compositions of chlorite from the MSZ at Unki Mine have total $\mathrm{Fe}\left\{=\mathrm{Fe}^{2+}+\mathrm{Fe}^{3+}(\mathrm{apfu})\right\}$ values which range from a low of 1.09 to a high of 3.43 with an average value of 2.34 (apfu) (Table 7, Supplementary Materials). Such low total Fe (apfu) values from the MSZ at Unki Mine are comparable to those from the Stillwater Complex and Mann Complex of 0.45-4.79 (average of 2.58) apfu and of 1.72-2.54 (average of 2.04) apfu, respectively. The low $\mathrm{Fe}^{2+} /\left(\mathrm{Fe}^{2+}+\mathrm{Mg}\right)$ ratios of MSZ chlorites, which vary from 0.26 to 0.5 , as well as the very low $\mathrm{Fe}^{3+}$ values characterize these MSZ chlorites as Fe-rich and unoxidized [24].

Equations for estimating the temperature of chlorite formation make use of the relationship between Fe in the octahedral site and temperature [61-63]. The three equations by these investigators were utilized in this investigation and comparisons of the compositions of chlorites from these equations are shown in Figure 19a,b. $\mathrm{Fe}^{2+} /\left(\mathrm{Fe}^{2+}+\mathrm{Mg}\right.$ ) is plotted against $\mathrm{Al}^{\mathrm{iv}}$ (apfu) (Figure 19a) and $\mathrm{Si} / \mathrm{Al}$ (in apfu) (Figure 19b) reveal that samples under investigation compare better with the chlorite composition fields of Cathelineau (1988) [62]. Consequently, high temperature calculations for chlorites utilized in this study only made use of the equations of Cathelineau (1988) [62].

The estimated temperatures of the hydrothermal fluid(s) that affected the MSZ at Unki Mine are shown in Figure 19c. These estimated temperatures of the hydrothermal event(s) range from 241 to 390 ${ }^{\circ} \mathrm{C}$ and from 491 to $640{ }^{\circ} \mathrm{C}$ (Figure 19c). This bimodal temperature distribution could indicate that two different hydrothermal alteration events affected the MSZ at Unki Mine: one in the relatively higher temperature range of $491-640{ }^{\circ} \mathrm{C}$, and another one in the relatively lower temperature $\left(241-390^{\circ} \mathrm{C}\right)$ range. These inferred temperature ranges of the hydrothermal event with is thought to have occurred during the cooling history of the MSZ at Unki Mine are broadly comparable to temperatures obtained from chlorite thermometry from the Duluth Complex (Gál et al., 2011). The lack of any stable isotope compositions consistent with meteoric fluids in the Great Dyke makes the involvement of meteoric fluids in mineralization in this intrusion unlikely. The observed bimodal temperature distribution is also consistent with amphibolite facies hydrothermal alteration for formation of magnesiohornblende and tschermakite, and the formation of tremolite-actinolite under greenschist facies conditions. 


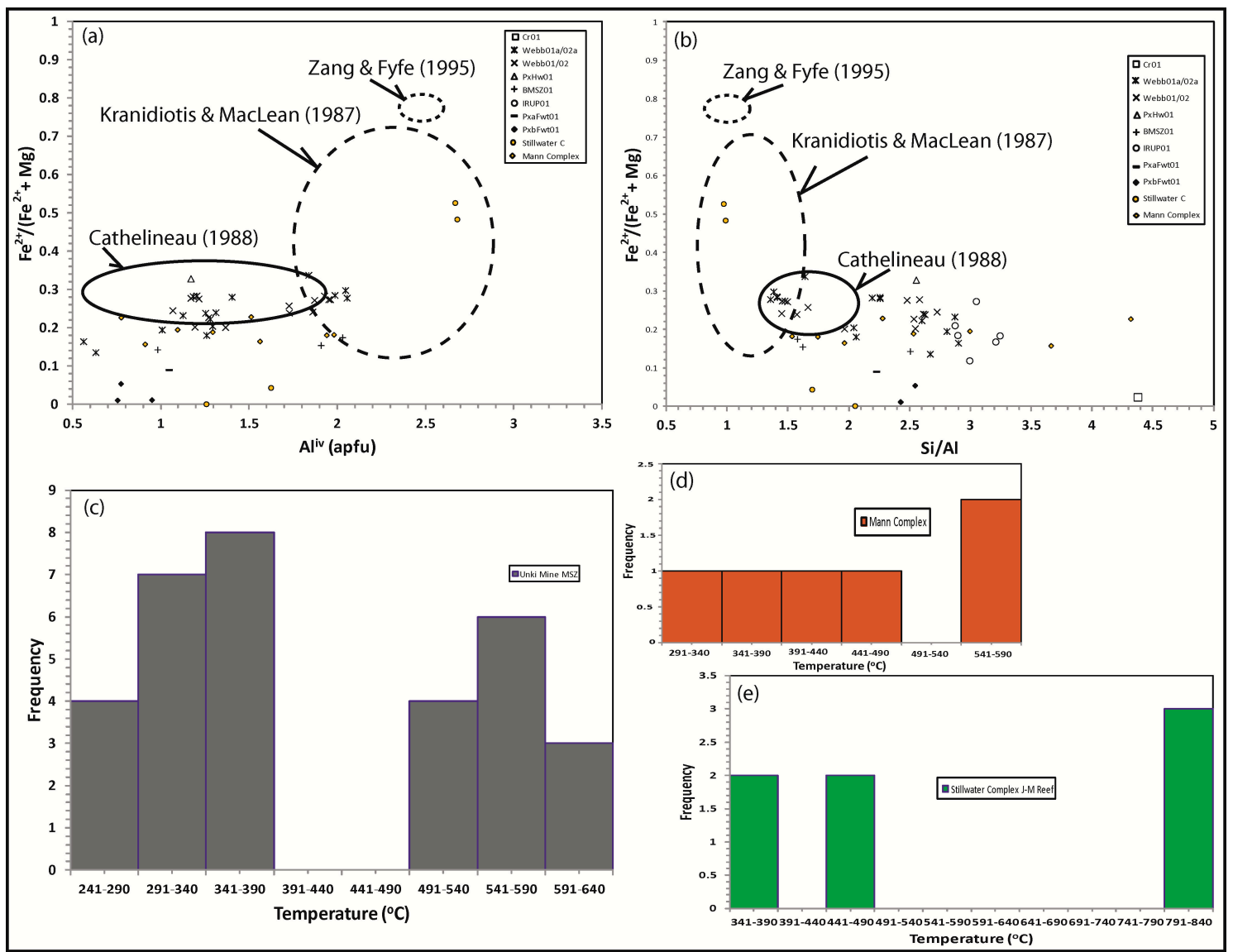

Figure 19. Plot of chlorite $\mathrm{Fe} /\left(\mathrm{Fe}+\mathrm{Mg}\right.$ ) versus $\mathrm{Al}^{\mathrm{iv}}$ (atoms per formula unit-apfu) (a) and chlorite $\mathrm{Fe} /(\mathrm{Fe}+\mathrm{Mg}$ ) versus $\mathrm{Si} / \mathrm{Al}$ (b) compared with those obtained from empirical temperature estimates of Kranidiotis and MacLean (1987) [61], Cathelineau (1988) [62], and Zang and Fyfe (1995) [63]. Compositional fields of chlorites from the Stillwater Complex and Mann Complex are plotted for comparison. Chlorites from the MSZ at Unki Mine are generally consistent with those from Cathelineau (1988) [62], and to a limited degree with those from Kranidiotis and MacLean (1987) [61]. A histogram of crystallization temperatures of chlorites from the MSZ at Unki Mine calculated by the empirical method of Cathelineau (1988) [62] is shown in (c), whereas (d) and (e) show chlorite crystallization temperatures calculated by the method of Cathelineau (1988) [62] for chlorites from the Mann Complex and Stillwater Complex, respectively.

These calculated temperatures of hydrothermal fluids which affected the MSZ at Unki Mine fall within, and at the slightly higher end, of the range of hydrothermal fluids [89]. The variation of temperatures obtained by chlorite thermometry with stratigraphic height across the investigated are is shown in Figure 20a and there appears to be a general increase from the base to the top of the MSZ, with a reversal to lower temperatures. Such a trend of increasing temperatures with stratigraphic height probably indicates the involvement of magmatic temperatures as temperature due to circulating heated fluids would likely result in a decrease in temperature with stratigraphic height. The drop to lower temperatures would be due to cooling of the intrusion before temperature increase again resulting in heating probably due to new magma injections.

It must be pointed out that several chlorite analyses from the MSZ have compositions that fall outside of the compositional calibrations of various calculations of chlorite thermometry (Figure 19a,b) and these results must be interpreted with caution. However, use of other chlorite thermometry equations suitable for low temperatures [64] indicates that the MSZ chlorites may have been formed at very low to medium temperatures except in a few samples (Figure 20a). This may have happened 
long after cooling of the intrusion. Chlorite thermometry temperatures lower than $200{ }^{\circ} \mathrm{C}$, for example, would indicate more enriched Great Dyke silicate $\delta^{18} \mathrm{O}$ values [90] than measured values which are consistent with high temperatures [91,92]. Further, low chlorite thermometry temperatures would also be inconsistent with the observations made in this work that chlorites occur in association with primary sulfides which would require higher temperatures of formation.

Both of the documented hydrothermal fluid events that affected the MSZ at Unki Mine must have been of magmatic origin, since oxygen isotope [91,92], $\mathrm{H}$ and S isotope [92] compositions and thermometry are consistent with high temperature, magmatic values for the Great Dyke. Indeed, Li et al. (2008) [92] also suggested hydrothermal alteration was responsible for affecting the mineralization of the MSZ at the Hartley Platinum Mine located in the Darwendale Subchamber of the Great Dyke. Prendergast (1990) [93] also reports on hydrosilicate "alteration" in the Wedza-Mimosa Platinum Deposit located in the Wedza Subchamber, the southernmost subchamber of the Great Dyke (Figure 1).

In comparison to other layered intrusions such as the Bushveld Complex, isotope data from the interval straddling the contact between the Ultramafic and Mafic Sequences of the Great Dyke indicate a less enriched composition of initial ${ }^{87} \mathrm{Sr} /{ }^{86} \mathrm{Sr}$ ratios $(0.7024-0.7028)$ and $\varepsilon_{\mathrm{Nd}}(-1$ to +1$)$ [94]. Sulfur isotope studies $\left(\delta^{34} S\right)$ of Great Dyke samples carried out by Li et al. (2008) [92] on pyrite, pyrrhotite, and pentlandite range from $0.1 \%$ to $1 \%$ and Maier et al. (2015) [94] obtained $\delta^{34} S$ on bulk-rock samples which range from $-0.3 \%$ to $0.3 \%$ all fall within the $0 \pm 5 \%$ range of mantle values [95]. Thus, relatively moderate amounts of contamination of the Great Dyke parent magma must have occurred, an indication that the Great Dyke crystallized from a single magma type. Unlike in the Bushveld Complex where mixing of compositionally distinct magmas is proposed to have caused sulfide melt saturation, formation of both PGE mineralization in the MSZ and the uppermost cyclic unit (Cyclic Unit 1) chromitite layers in the Great Dyke may have been triggered by silicate fractionation and magma mixing between resident magma and unevolved replenishing magma $[14,25,43,45,48,49,74,94]$. Li and Ripley (2005) [96] have suggested that sulfide melt saturation in the hybrid magma can be triggered only if both mixing magmas themselves are nearly saturated in sulfide melt, which seems unlikely to be the case in the Great Dyke in relation to the new replenishing magma.

However, unlike at Hartley Platinum Mine in the Darwendale Subchamber of the Great Dyke where alteration minerals such as epidote, talc, calcite and ankerite are reported to occur, these minerals were not observed in the MSZ at Unki Mine. Studies of radiogenic isotopes, also from Hartley Platinum Mine, of Sm-Nd and $\mathrm{Rb}-\mathrm{Sr}\left(\varepsilon_{\mathrm{Nd}}\right.$ values of mostly -1 to +1 and initial ${ }^{87} \mathrm{Sr} /{ }^{86} \mathrm{Sr}$ isotope ratios of $0.7024-0.7028$; [94]) and Re-Os isotopes (narrow initial ${ }^{187} \mathrm{Os} /{ }^{188}$ Os ratios range of between 0.1106 and 0.1126; [97]) are consistent with magmatic signatures for the Great Dyke as only moderate amounts of crustal contamination must have occurred in the Great Dyke. Results from these radiogenic isotope studies by Maier et al. (2015) [94] and Schoenberg et al. (2003) [97], thus, help rule out the possible involvement of significant amounts of external fluids in the mineralization of the Great Dyke, further lending support to the findings from this investigation that the hydrothermal fluids which interacted with the MSZ at Unki Mine are of magmatic origin.

The occurrence of hydrothermal alteration events of different temperatures observed in this investigation seems not to be a feature only associated with the MSZ of the Great Dyke, as the J-M Reef of the Stillwater Complex (Figure 19d) and the Mann Complex (Figure 19e) are also characterized by chlorites with record distinct temperature ranges. This has implications for the involvement of multiple hydrothermal alteration events in the concentration of magmatic PGEs in layered intrusions.

Mogessie et al. (1991) [98], Ripley et al. (1993) [99], Severson (1994) [100], and Gál et al. (2011, 2013) $[23,101]$ have all documented hydrothermal processes and their roles in the concentration of PGE remobilization in the troctolitic intrusions of the Duluth Complex in Minnesota, USA. In this complex, Mogessie et al. (1991) [98] observed that $\mathrm{Cu}$ and PGEs were remobilized from the primary magmatic mineralization by $\mathrm{C}, \mathrm{O}, \mathrm{H}, \mathrm{S}$, and $\mathrm{Cl}$-enriched fluids along fracture zones whereas Gál et al. (2011) [23] described vein-type, hydrothermal Cu-mineralization associated with actinolite-chlorite-prehnite-pumpelleyite-calcite alteration assemblage in the hanging-wall of the SKI 
at the Filson Creek deposit in the same intrusion. In the Babbitt Cu-Ni deposit of the Bathtub intrusion, Ripley et al. (1993) [99] interpreted that hydrothermal remobilization of primary ores occurred on the basis of hydrogen and oxygen isotope studies Ripley et al (1993) [99] concluded that fluids both from magmatic and metasedimentary sources were responsible.

Two-pyroxene thermometry yielded temperatures that range from 850 to $981{ }^{\circ} \mathrm{C}$ (Figure 20a,b; Table 8), using the equations of both Putirka (2008) [66] and of Brey and Kohler (1990) [65], with the exception of a relatively lower temperature of $670{ }^{\circ} \mathrm{C}$ which was obtained using the equation of Brey and Kohler (1990) [65]. These pyroxenes are inferred to be been initially characterized by magmatic temperatures that were subsequently affected by the hydrothermal alteration as oxygen isotope thermometry yielded magmatic temperatures in the Mafic Sequence which range from 1016 to $1155^{\circ} \mathrm{C}$, with an average temperature of $1091{ }^{\circ} \mathrm{C}$ [91]. The Mafic Sequence, with the exception of a $2.3 \mathrm{~m}$-wide zone of alteration located between 13 and $16 \mathrm{~m}$ above the Mafic Sequence/Ultramafic Sequence contact [102], is characterized by fresh plagioclase, clinopyroxene, and orthopyroxene cumulates that do not show any evidence of hydrothermal alteration [100,102], implying that the hydrothermal event(s) which affected the Great Dyke did not affect much of the gabbroic rocks overlying the Ultramafic Sequence. Studies of the Ultramafic Sequence beneath the mineralized P1 layer can address the extent of this hydrothermal activity within the Ultramafic Sequence.

Table 8. Calculated two pyroxene temperatures and pressures for Unki Mine MSZ samples.

\begin{tabular}{|c|c|c|c|c|c|c|}
\hline $\begin{array}{l}\text { Author } \\
\text { (Year) }\end{array}$ & $\begin{array}{c}\text { Brey and Kohler } \\
\text { (1990) [65] }\end{array}$ & & Putirka & 008) [66] & & $\mathbf{K}_{\mathbf{D}}$ \\
\hline Sample & $\mathrm{T}\left({ }^{\circ} \mathrm{C}\right)$ & $\begin{array}{l}\text { Equation } \\
36 \mathrm{~T}\left({ }^{\circ} \mathrm{C}\right)\end{array}$ & $\begin{array}{l}\text { Equation } \\
37 \mathrm{~T}\left({ }^{\circ} \mathrm{C}\right)\end{array}$ & $\begin{array}{l}\text { Equation } \\
38 \mathrm{P} \text { (kbar) }\end{array}$ & $\begin{array}{l}\text { Equation } \\
39 \mathrm{P} \text { (kbar) }\end{array}$ & $\begin{array}{c}\text { Observed } \\
\mathrm{K}_{\mathrm{D}}(\mathrm{Fe}-\mathrm{Mg})\end{array}$ \\
\hline CR01 P5 & 913.9 & 961.5 & 896.9 & 3.4 & 4.0 & 0.949 \\
\hline Webb01a P7 & 915.9 & 950.8 & 918.7 & 2.6 & 4.0 & 0.710 \\
\hline Webb01 P38 & 875.1 & 961 & 890.1 & 2.4 & 2.6 & 0.824 \\
\hline Webb02 P88 & 844.5 & 931.3 & 872.6 & 1.8 & 4.3 & 0.724 \\
\hline Peg01 P90 & 881.5 & 942.4 & 900.3 & 0.8 & 3.6 & 0.696 \\
\hline Peg01 P53 & 934.1 & 972.8 & 919.3 & 2.8 & 3.1 & 0.679 \\
\hline BMSZ01 P31 & 932 & 981.1 & 947.7 & 3.7 & 4.8 & 0.734 \\
\hline IRUP01 P109 & 670.3 & 917.9 & 850.2 & 1.8 & 3.8 & 0.621 \\
\hline
\end{tabular}

Use of the calculated pressures (1.8-4.8 kbar) (Figure 20c,d; Table 8) obtained from using the temperatures calculated from the equations of Putirka (2008) [66] and of Brey and Kohler (1990) [65] allows one to estimate the thickness of the overburden above the MSZ. If one assumes lithostatic conditions $\left(3000 \mathrm{~kg} / \mathrm{m}^{3}\right)$ the overburden during the hydrothermal alteration of the MSZ ranges from 6.1 to $12.6 \mathrm{~km}$ and 8.8-16.3 km using Equations (38) and (39) of Putirka (2008) [66], respectively. These thicknesses are much higher than the current $200 \mathrm{~m}$ depth of the MSZ at Unki Mine, and even higher than the estimated total thickness of the Mafic Sequence of $1150 \mathrm{~m}$ in the Darwendale and Sebakwe Subchambers $[30,103]$. Thus, at the level of the MSZ at Unki Mine, the thickness of the overburden above the $1150 \mathrm{~m}$ maximum thickness of the Great Dyke (Mafic Sequence) ranged from 5 to $11 \mathrm{~km}$ using Equation (38) of Putirka (2008) [66] and from 7.7 to $15 \mathrm{~km}$ using Equation (39) of Putirka (2008) [66]. 


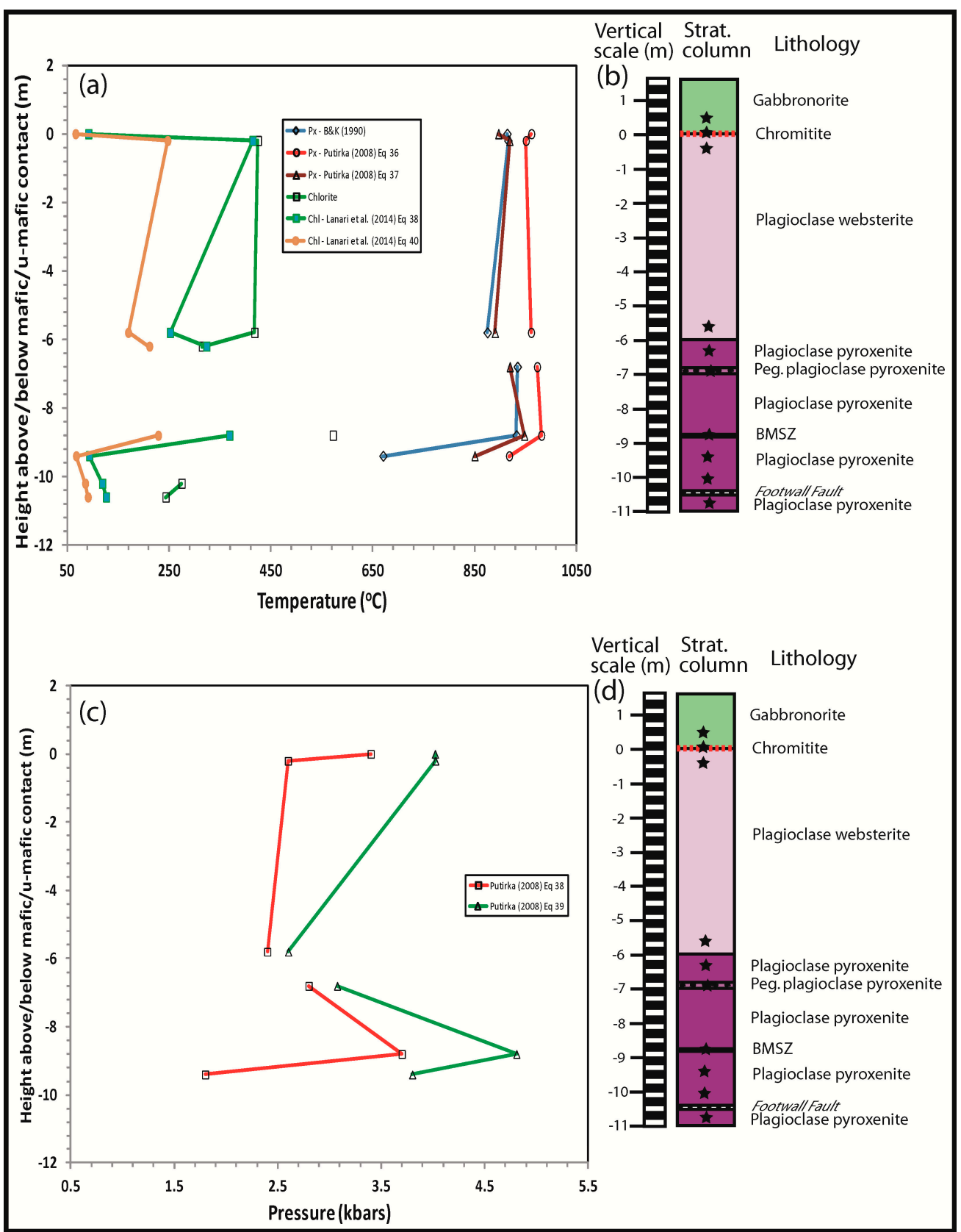

Figure 20. (a) Plot of temperatures obtained from chlorite as well as from two-pyroxene thermometry of versus height across the MSZ. Corresponding lithologic units are shown in (b) using the equations of Brey and Kohler (1986) [65] and Putirka (2008) [66]. Lower temperatures for chlorites calculated using the equations of Lanari et al. [64] and relatively higher temperatures for chlorites were calculated using the equation of Cathelineau [62]. (a) Plot of pressures obtained from two-pyroxene thermometry of versus height across the MSZ. Corresponding lithologic units are shown in (b). Variation of calculated pressures based on the Equations (38) and (19) of Putirka (2008) [66] across the MSZ. Pressures that were calculated using Equation (39) are slightly higher than those calculated using Equation (38).

Metamorphic conditions experienced in some greenstone belts in the Zimbabwe craton, for example the Shamva greenstone belt, is low pressure but high temperature type, and range from upper amphibolite-facies $\left(600-650{ }^{\circ} \mathrm{C}, 3-4 \mathrm{kbar}\right)$ conditions near the margins of the greenstone belt to greenschist facies $\left(450-550{ }^{\circ} \mathrm{C}, 1.5-2.5 \mathrm{kbar}\right)$ within the core of the greenstone belt such as at Shamva Mine [104]. These are pressures and temperatures comparable to those obtained in this work. 
Thus, mineralization in the MSZ of the Great Dyke may have occurred at depths comparable to those under which metamorphism of some of the greenstone belts in the Zimbabwe craton occurred.

Other investigators have also documented the involvement of hydrothermal alteration is other large layered intrusions elsewhere. Evidence for hydrothermal alteration that locally altered magmatic silicates, recrystallized BMS aggregates and remobilized sulfides and PGEs in the J-M reef of the Stillwater Complex has been documented by Polovina et al. (2004) [10]. The alteration assemblage in this Complex is dominated by chlorite, clinozoisite, serpentine, calcite, talc, white mica, magnetite, tremolite, Cl-rich ferropargasite, and quartz [10]. Hydrothermal alteration of magmatic Ni-Cu-PGE deposits has also been reported to occur in the Tootoo and Mequillon magmatic sulfide deposits located in the Cape Smith Belt, Canada [22]. Olivine melagabbronorites, the host rocks in the Tootoo and Mequillon magmatic sulfide deposits, were pervasively altered to hydrous mineral assemblages dominated by chlorite, tremolite-actinolite, and relict late-magmatic hornblende that are consistent with greenschist facies metamorphism [22]. Large-scale and very saline hydrothermal fluid activity is also interpreted to have affected rocks of the Sudbury Complex and in the process caused remobilization of both base metals and PGEs $[105,106]$.

Hydrothermal alteration by meteoric water is thought to be responsible for decoupling of $S$ and $\mathrm{Cu}$ occurring in the Sonju Lake intrusion of the of the 1.1 Ga Midcontinent rift-related Beaver Bay Complex in north-eastern Minnesota, USA [92,107]. Thermal migration zone refining is a process whereby igneous activity at convergent margin builds a thick volcanic pile which becomes a barrier to further magma ascent, leading to magma underplating by injection of sills at the base of the volcanic pile [108]. When magma arrives at the location of underplating, it reacts and releases heat and water to the overlying materials (i.e., previously intruded sills) and this results in a downward moving zone having a near-steady-state temperature gradient [108]. This leads to compositional differentiation by wet thermal migration then occurs in the middle of the underplated region but not on the more rapidly cooled edges of the sills, and this is thought by Lundstrom (2009) [108] to take place over time scales of millions of year. If the Sonju Lake intrusion was formed by a top-down process of sill injection and reaction (thermal migration zone refining) [109], then the PGE reef (PGE-Cu-S interval) in this intrusion was interpreted to have been formed as a moving sulfide band passed downward through a mineral-melt mush at the particular temperature of sulfide saturation [110]. Further, in the Sonju Lake intrusion, disseminated sulfides have $\delta^{34} S$ values that range from $-2.2 \%$ to $+3 \%$ o (V-CDT), within the range of mantle-derived minerals and rocks, suggesting that contamination by country rock sulfur was not an important process in the formation of the metal-rich interval [104]. $\delta^{18} \mathrm{O}$ values of plagioclase from the Sonju Lake intrusion range widely from $5.6 \%$ to $12.0 \%$ (V-SMOW), an indication that a relatively low ${ }^{18} \mathrm{O}$ fluid $\left(\delta^{18} \mathrm{O} \sim 3 \%{ }_{0}-5 \%\right.$ ) interacted with the rocks of the intrusion at temperatures less than $\sim 275{ }^{\circ} \mathrm{C}$ based on oxygen isotope thermometry and the prehnite-pumpellyite to greenschist facies transition $[92,104]$. Some of alteration assemblages such as chlorite and actinolite, as well as magmatic stable isotope compositions reported by Park et al. (2004) [107] for the Sonju Lake intrusion are broadly comparable to those reported in the present investigation and by previous investigators on the Great Dyke.

PGE-bearing horizons, or reefs, in layered intrusions are generally thought to have been formed during upward accumulation of mineral deposits. Within the context of the cumulate model (where crystals accumulate from the bottom upwards through crystal accumulation from a large volume of magma), the origin of PGE reefs is currently being debated between a number of models [111]. In the orthomagmatic model, the PGE deposits are thought to have been formed when immiscible sulfide melts that scavenged PGEs from the silicate melt as they settle due to gravity [112]. In the hydromagmatic model, PGE deposits are thought to have been formed when a magmatic hydrothermal fluid generated in the already formed crystal pile moves upward, scavenges and concentrates the PGEs and deposits them in the reef $[12,113]$. In the micro-nuggets model, metallic micro-nuggets are thought to segregate from magma and concentrate PGEs [114]. The assumption in these three models describing PGE mineralization in layered intrusions is that layered intrusions were formed during 
the upward accumulation of crystals settling in a magma chamber (i.e., the cumulate model). PGE reefs have also recently been proposed to form if smaller layered intrusion formed incrementally by top-down sill accumulation $[109,115]$ where no magma chamber may have existed. Findings from this work lend support to both an orthomagmatic model as well as a hydromagmatic imprint for the origin of mineralization in the MSZ at Unki Mine. Since this study was on silicate mineral compositions and did not focus on PGEs, no evaluation of the micro-nugget model can thus be undertaken.

In the Great Dyke, all three models (orthomagmatic, hydromagmatic, and micro-nugget models) have been proposed for the origin of the MSZ [41,43,49,50,113]. Stratigraphic offsets in peak concentrations of PGEs and BMS which occur in the MSZ [14,43] have, in part, been attributed by Li et al. (2008) [92] to the interaction between magmatic PGE-bearing BMS assemblages and hydrothermal fluids. Li et al. (2008) [92] presented mineralogical and textural evidence from the Hartley Platinum Mine located in the Darwendale Subchamber of the Great Dyke which they interpreted to indicate that alteration of BMS and mobilization of metals and S occurred during hydrothermal alteration. Sulfur isotope data of pyrite, pyrrhotite, and chalcopyrite ranging from $0.1 \%$ to $0.8 \%$, as well as $\mathrm{O}$ isotope data for orthopyroxene ranging from $5.1 \%$ to $6.5 \%$ from the MSZ suggest that the fluids involved in the alteration were of magmatic origin [92]. Further, actinolite has both $\mathrm{O}$ and $\mathrm{H}$ isotope data ranging from $5.0 \%$ to $5.6 \%$ and $64 \%$ to $73 \%$, respectively, which Li et al. (2008) [92] interpreted to be consistent with magmatic fluids.

According to Oberthür et al. (2003) [17], variations in Pt/Pd ratios in the MSZ may be related to hydrothermal alteration due to the observation that most of the Pd and $\mathrm{Rh}$ are hosted in pentlandite, whereas Pt dominantly occurs in the form of discrete minerals. According to Li et al. (2008) [92], minor $(<5 \mathrm{vol} \%)$ to significant (20 vol \%) alteration is present in the MSZ. Actinolite, epidote, carbonate, talc, magnetite, and pyrite are the most common secondary minerals. Actinolite alteration occurs throughout the MSZ, but it is most intense in the sample which occurs immediately below the peak in Pd content and also occurring immediately below the peak in Pt content in the PGE subzone [17,92]. Boudreau and Meurer (1999) [116] argued that a chromatographic process that involved magmatic fluids was responsible for the Pt/Pd offsets in the MSZ.

\section{Conclusions}

At least two generations of sulfide mineralization at Unki Mine: one of magmatic nature based on sulfides which occur as inclusions in chromite and silicate crystals and the second one occurring in association with hydrothermal minerals such as chlorite and amphibole. Hydrothermal alteration likely resulted in the formation of diopsides which are enriched in calcium relative to most magmatic clinopyroxenes.

Chlorite thermometry yields estimates of temperatures which range from 241 to $640{ }^{\circ} \mathrm{C}$, and from 390 to $491{ }^{\circ} \mathrm{C}$ of the hydrothermal event(s) of magmatic origin which likely affected the mineralization of the MSZ at Unki Mine.

Two-pyroxene thermometry yields temperatures that range from 850 to $981{ }^{\circ} \mathrm{C}$, probably indicating a hydrothermal imprint on the minerals of the MSZ.

An overburden during the hydrothermal alteration of the MSZ at Unki Mine probably ranged from 6.1 to $12.6 \mathrm{~km}$ or from 8.8 to $16.3 \mathrm{~km}$, implying pressures for the formation of the MSZ ranged from 1.8 to 4.8 kbars.

Supplementary Materials: The following are available online at www.mdpi.com/2075-163X/7/7/127/s1.

Acknowledgments: Funding for microprobe work was obtained from a UNC Pembroke Office of Graduate Studies and Research grant that covered the costs of microprobe analyses, and it is gratefully acknowledged. Thin section costs were covered by a Summer Research Fellowship from the Teaching and Learning Center at UNC Pembroke, which is also gratefully acknowledged. Caston Musa of Unki Mine, Anglo American Corporation Zimbabwe, is thanked for his help with getting this investigation started. Caston Musa and Collins Mwatahwa are acknowledged for discussions on some aspects of Unki Mine geology. Comments by the Editor and two anonymous references helped improve the manuscript substantially, and they are gratefully acknowledged. Nick Foster, Steven Singletary and Allen Glazner helped with various aspects of microprobe work. 
Conflicts of Interest: The author declares no conflicts of interest.

\section{References}

1. Campbell, I.H.; Barnes, S.J. A model for the geochemistry of the platinum group elements in magmatic sulphide deposits. Can. Mineral. 1984, 22, 151-160.

2. Bezmen, N.I.; Asif, M.; Brugmann, G.E.; Romanenko, I.M.; Naldrett, A.J. Distribution of palladium, rhodium, ruthenium, iridium, osmium and gold between sulphide and silicate melts. Geochim. Cosmochim. Acta 1994, 58, 1251-1260. [CrossRef]

3. Campbell, I.H.; Naldrett, A.J.; Barnes, S.J. A model for the origin of the platinum-Rich sulphide horizons in the Bushveld and Stillwater Complexes. J. Petrol. 1983, 24, 133-185. [CrossRef]

4. Naldrett, A.J. Magmatic Sulfide Deposits: Geology, Geochemistry and Exploration; Springer: Berlin, Germany, 2004; 727p.

5. Ballhaus, C.G.; Stumpfl, E.F. Sulfide and platinum mineralization in the Merensky Reef: Evidence from hydrous silicates and fluid inclusions. Contrib. Mineral. Petrol. 1986, 94, 193-204. [CrossRef]

6. Boudreau, A.E.; Mathez, E.A.; McCallum, I.S. Halogen geochemistry of the Stillwater and Bushveld Complexes: Evidence for transport of the platinum-group elements by Cl-rich Fluids. J. Petrol. 1986, 27, 967-986. [CrossRef]

7. Li, C.; Ripley, E.M.; Merino, E.; Maier, W.D. Replacement of base metal sulfides by actinolite, epidote, calcite, and magnetite in the UG2 and Merensky reef of the Bushveld Complex, South Africa. Econ. Geol. 2004, 99, 173-184. [CrossRef]

8. Boudreau, A.E.; McCullum, I.S. Concentration of platinum-group elements by magmatic fluids in layered intrusions. Econ. Geol. 1992, 87, 1830-1848. [CrossRef]

9. Meurer, W.P.; Wilmore, C.C.; Boudreau, A.E. Metal redistribution during fluid exsolution and migration-an example from the Middle Banded series of the Stillwater Complex, Montana. Lithos 1999, 47, 143-156. [CrossRef]

10. Polovina, J.S.; Hudson, D.M.; Jones, R.E. Petrographic and geochemical characteristics of postmagmatic hydrothermal alteration and mineralization in the J-M reef, Stillwater Complex, Montana. Can. Mineral. 2004, 42, 261-277. [CrossRef]

11. Li, C.; Ripley, E.M. Formation of Pt Fe alloy by desulfurization of Pt Pd sulfide in the J-M reef of the Styillwater Complex, Montana. Can. Mineral. 2006, 44, 895-903. [CrossRef]

12. Boudreau, A.E. The Stillwater Complex, Montana-Overview and the significance of volatiles. Mineral. Mag. 2016, 80, 585-637. [CrossRef]

13. Prendergast, M.D.; Wilson, A.H. The Great Dyke of Zimbabwe II. Mineralisation and mineral deposits. In Magmatic Sulphides-The Zimbabwe Volume; Prendergast, M.D., Jones, M.J., Eds.; Institution of Mining and Metallurgy: London, UK, 1989; pp. 21-42.

14. Oberthür, T. Platinum-group element mineralization of the Main Sulfide Zone, Great Dyke, Zimbabwe. Rev. Econ. Geol. 2011, 17, 329-349.

15. Schiffries, C.M.; Rye, D.M. The Bushveld hydrothermal system: Field and petrologic evidence. Am. J. Sci. 1987, 287, 566-595. [CrossRef]

16. Schiffries, C.M.; Rye, D.M. Stable isotope systematics of the Bushveld Complex: II. Constraints on hydrothermal processes in layered intrusions. Am. J. Sci. 1990, 290, 209-245. [CrossRef]

17. Oberthür, T.; Weiser, T.W.; Gast, L.; Kojonen, K. Geochemistry and mineralogy of the platinum-group elements at Hartley Platinum Mine, Zimbabwe. Part 1: Primary distribution patterns in pristine ores of the Main Sulfide Zone of the Great Dyke. Miner. Deposita 2003, 38, 327-343. [CrossRef]

18. Oberthür, T.; Weiser, T.W.; Gast, L.; Kojonen, K. Geochemistry and mineralogy of the platinum-group elements at Hartley Platinum Mine, Zimbabwe. Part 2: Supergene redistribution in the oxidized Main Sulfide Zone of the Great Dyke, and alluvial platinum-group minerals. Miner. Deposita 2003, 38, 344-355. [CrossRef]

19. Essaifi, A.; Capdevila, R.; Fourcade, S.; Lagarde, J.-L.; Ballèvre, M.; Marignac, C. Hydrothermal alteration, fluid flow and volume change in shear zones: The layered mafic-ultramafic Kettara intrusion (Jebilet Massif, Variscan belt, Morocco). J. Metamorph. Geol. 2004, 22, 25-43. [CrossRef] 
20. Zhang, X.; Pirajno, F.; Qin, D.; Fan, Z.; Liu, G.; Nian, H. Baimazhai Yunnan Province, China, a hydrothermally modified magmatic nickel-cooper-PGE sulfide deposit. Int. Geol. Rev. 2006, 48, 725-741. [CrossRef]

21. Garuti, G.; Proenza, J.A.; Zaccarini, F. Distribution and mineralogy of platinum-group elements in altered chromitites of the Campo Formoso layered intrusion (Bahia State, Brazil): Control by magmatic and hydrothermal processes. Mineral. Petrol. 2007, 86, 159-188. [CrossRef]

22. Liu, Y.; Mungall, J.E.; Ames, D.E. Hydrothermal redistribution and local enrichment of platinum group elements in the Tootoo and Mequillon magmatic sulfide deposits, South Raglan Trend, Cape Smith Belt, New Quebec Orogen. Econ. Geol. 2016, 111, 467-487. [CrossRef]

23. Gál, B.; Molnár, F.; Peterson, D.M. Cu-Ni-PGE mineralization in the South Filson Creek area, South Kawishiwi intrusion, Duluth Complex: Mineralization styles, magmatic and hydrothermal processes. Econ. Geol. 2011, 106, 481-509. [CrossRef]

24. Benkó, Z.; Mogessie, A.; Molnár, F.; Krenn, K.; Poulson, S.R.; Hauck, S.A.; Severson, M.J.; Arehart, G.B. Hydrothermal alteration and Cu-Ni-PGE mobilization in the charnockitic rocks of the footwall of the South Kawishiwi intrusion, Duluth Complex, USA. Ore Geol. Rev. 2015, 67, 170-188. [CrossRef] [PubMed]

25. Wilson, A.H.; Prendergast, M.D. The Great Dyke of Zimbabwe I. Tectonic setting, stratigraphy, petrology, structure, emplacement and crystallization. In Magmatic Sulphides-The Zimbabwe Volume; Prendergast, M.D., Jones, M.J., Eds.; Institution of Mining and Metallurgy: London, UK, 1989; pp. 1-20.

26. Wilson, J.F. The craton and its cracks: Some of the behaviour of the Zimbabwe blocks from the Late Archaean to the Mesozoic in response to horizontal movements, and the significance of some of its mafic dyke fracture patterns. J. Afr. Earth Sci. 1990, 10, 483-501. [CrossRef]

27. Worst, B.G. The differentiation and structure of the Great Dyke of Southern Rhodesia. Trans. Geol. Soc. S. Afr. 1958, 61, 283-354.

28. Worst, B.G. The Great Dyke of Southern Rhodesia. In Southern Rhodesia Geological Survey Bulletin No. 47; British Geological Survey: Nottingham, UK, 1960; 234p.

29. Podmore, F.; Wilson, A.H. A reappraisal of the structure, geology and emplacement of the Great Dyke, Zimbabwe. In Mafic Dyke Swarms; Halls, H.C., Fahrig, W.F., Eds.; Special Paper Geological Association of Canada: St. John's, NL, Canada, 1987; pp. 433-444.

30. Wilson, A.H.; Wilson, J.F. The Great 'Dyke'. In Precambrian of the Southern Hemisphere; Hunter, D.R., Ed.; Elsevier: Amsterdam, The Netherlands, 1981; pp. 572-578.

31. Wilson, A.H.; Murahwi, C.Z.; Coghill, B.M. The geochemistry of the PGE Subzone in the Selukwe Subchamber, Great Dyke: An intraformational layer model for platinum-group element enrichment in layered intrusions. Mineral. Petrol. 2000, 68, 115-140. [CrossRef]

32. Wilson, A.H. The geology of the Great 'Dyke', Zimbabwe: The ultramafic rocks. J. Petrol. 1982, 23, $240-292$. [CrossRef]

33. Prendergast, M. The chromite ore field of the Great Dyke, Zimbabwe. In Evolution of Chromite Ore Fields; Stowe, C.W., Ed.; Van Nostrand Reinhold: New York, NY, USA, 1987; pp. 89-108.

34. Wilson, J.F. A preliminary reappraisal of the Rhodesian Basement Complex. Geol. Soc. S. Afr. 1979, 5, 1-23.

35. Stowe, C.W. Wrench fault tectonics in the Archaean Rhodesian Craton. Trans. Geol. Soc. S. Afr. 1980, 83, 193-206.

36. Wilson, J.F.; Jones, D.L.; Kramers, J.D. Mafic Dyke Swarms in Zimbabwe. In Mafic Dyke Swarms; Halls, H.C., Fahrig, W.F., Eds.; Geological Association of Canada: St. John's, NL, Canada, 1987; Volume 33, pp. $433-444$.

37. Oberthür, T.; Davis, D.W.; Blenkinsop, T.G.; Höhndorf, A. Precise U-Pb mineral ages, Rb-Sr and Sm-Nd systematics for the Great Dyke, Zimbabwe-Constraints on late Archean events in the Zimbabwe Craton and Limpopo Belt. Precambrian Res. 2002, 113, 293-305. [CrossRef]

38. Wingate, M.T.D. Ion-microprobe U-Pb zircon and baddeleyite ages for the Great Dyke and its satellite dykes, Zimbabwe. S. Afr. J. Geol. 2000, 103, 74-80. [CrossRef]

39. Wilson, A.H.; Murahwi, C.Z.; Coghill, B.M. Stratigraphy, geochemistry and PGE mineralization of the central zone of the Selukwe Subchamber, Great Dyke. J. Afr. Earth Sci. 2000, 30, 633-653. [CrossRef]

40. Bichan, R. The evolution and structural setting of the Great Dyke, Rhodesia. In African Magmatism and Tectonics; Clifford, T.N., Gass, I.G., Eds.; Oliver and Boyd: Edinburgh, UK, 1970; pp. 51-71.

41. Naldrett, A.J.; Wilson, A.H. Horizontal and vertical variations in noble metals in the Great Dyke of Zimbabwe: A model for the origin of PGE mineralization by fractional segregation. Chem. Geol. 1990, 88, 279-300. [CrossRef] 
42. Bichan, R. Origin of chromite seams in the Hartley complex of the Great Dyke, Rhodesia. Econ. Geol. Monogr. 1969, 4, 95-113.

43. Prendergast, M.D.; Keays, R.R. Controls of platinum-group element mineralization and the origin of the PGE-rich Main Sulphide Zone in the Wedza Subchamber of the Great Dyke, Zimbabwe: Implications for the genesis of, and exploration for, stratiform PGE mineralization in layered intrusions. In Magmatic Sulphides-The Zimbabwe Volume; Prendergast, M.D., Jones, M.J., Eds.; Institution of Mining and Metallurgy: London, UK, 1989; pp. 43-69.

44. Wilson, A.H.; Tredoux, M. Lateral and vertical variation of the platinum-group elements, and petrogenetic controls on the sulphide mineralisation in the P1 Pyroxenite Layer of the Darwendale Subchamber of the Great Dyke, Zimbabwe. Econ. Geol. 1990, 85, 556-584. [CrossRef]

45. Wilson, A.H.; Prendergast, M.D. Platinum-group element mineralisation in the Great Dyke, Zimbabwe, and its relationship to magma evolution and magma chamber structure. S. Afr. J. Geol. 2001, 104, 319-342. [CrossRef]

46. Oberthür, T. Platinum-group element mineralization of the Great Dyke, Zimbabwe. In CIM Special Volume 54; Cabri, L.J., Ed.; Canadian Institute of Mining, Metallurgy and Petroleum: Westmount, QC, Canda, 2002; pp. 483-506.

47. Wagner, P.A. The geology of a portion of the Belingwe Districtof Southern Rhodesia. Trans. Proc. Geol Soc. S. Afr. 1914, 17, 39-54.

48. Prendergast, M.D. The Wedza-Mimosa platinum deposit, Great Dyke, Zimbabwe: Layering and stratiform PGE mineralization in a narrow mafic magma chamber. Geol. Mag. 1991, 128, 235-249. [CrossRef]

49. Wilson, A.H. Compositional and Lithological Controls on the PGE-Bearing Sulphide Zones in the Selukwe Subchamber, Great Dyke: A Combined Equilibrium-Rayleigh Fractionation Model. J. Petrol. 2001, 42, 1845-1867. [CrossRef]

50. Wilson, A.H.; Naldrett, A.J.; Tredoux, M. Distribution and controls of platinum-group element and base metal mineralization in the Darwendale Subchamber of the Great Dyke, Zimbabwe. Geology 1989, 17, 649-652. [CrossRef]

51. Barnes, S.J.; McIntyre, J.R.; Nisbet, B.W.; Williams, C.R. Platinum-group element mineralisation in the Munni Munni Complex, Western Australia. Mineral. Petrol. 1990, 42, 141-164. [CrossRef]

52. Barnes, S.J. Partitioning of the platinum group elements and gold between silicate and sulphide magmas in the Munni Munni Complex, Western Australia. Geochim. Cosmochim. Acta 1993, 57, 1277-1290. [CrossRef]

53. Johan, Z.; Ohnenstetter, D.; Naldrett, A.J. Platinum-Group Minerals and Associated Oxides and Base Metal Sulfides of the Main Sulfide Zone, Great Dyke, Zimbabwe. Bull. Geol. Soc. Finl. 1989, 6, 53-54.

54. Stowe, C.W. Intersecting fold trends in the Rhodesian Basement Complex, south and west of Selukwe. Annex. Trans. Geol. Soc. S. Afr. 1968, 71, 53-78.

55. Scoon, R.; Mitchell, A. Discordant iron-rich ultramafic pegmatites in the Bushveld Complex and their relationship to iron-rich intercumulus and residual liquids. J. Petrol. 1994, 35, 881-917. [CrossRef]

56. Reid, D.L.; Basson, I.J. Iron-rich ultramafic pegmatite replacement bodies within the Upper Critical Zone, Rustenburg Layered Suite, Northam Platinum Mine, South Africa. Mineral. Mag. 2002, 66, 895-914. [CrossRef]

57. Whitney, D.L.; Evans, B.W. Abbreviations for names of rock-forming minerals. Am. Mineral. 2010, 95, 185-187. [CrossRef]

58. Chaumba, J.B.; Mandalamo, H.R.; Ogola, J.S.; Cox, J.A.; Fleisher, C.J. Petrography, sulfide mineral chemistry, and sulfur isotope data from the breccia pipes at Musina copper district, Limpopo Province, South Africa: Evidence for a breccia pipe origin? J. Afr. Earth Sci. 2016, 120, 141-159. [CrossRef]

59. Jenner, G.A. Trace element geochemistry of igneous rocks: Geochemical nomenclature and analytical geochemistry. In Trace Element Geochemistry of Volcanic Rocks: Applications for Massive Sulphide Exploration; Wyman, D.A., Ed.; Geological Association of Canada: St. John's, NL, Canada, 1996; Volume 12, pp. 51-77.

60. Armstrong, J.T. Quantitative Analysis of Silicate and Oxide Minerals: Comparison of the Monte Carlo, ZAF and $\Phi(\rho Z)$ Procedures-Microbeam Analysis; Newbury, D.E., Ed.; San Francisco Press: San Francisco, CA, USA, 1988; pp. 239-246.

61. Kranidiotis, P.; MacLean, W.H. Systematics of chlorite alteration at the Phelps Dodge massive sulfide deposit, Mattagami, Quebec. Econ. Geol. 1987, 82, 1898-1911. [CrossRef] 
62. Cathelineau, M. Cation site occupancy in chlorites and illites as a function of temperature. Clay Mineral. 1988, 23, 471-485. [CrossRef]

63. Zang, W.; Fyfe, W.S. Chloritization of the hydrothermally altered bedrocks at the Igarapé Bahia gold deposit, Carajás, Brazil. Miner. Deposita 1995, 30, 30-38. [CrossRef]

64. Lanari, P.; Wagner, T.; Vidal, O. A thermodynamic model for di-trioctahedral chlorite from experimental and natural data in the system $\mathrm{MgO}-\mathrm{FeO}-\mathrm{Al}_{2} \mathrm{O}_{3}-\mathrm{SiO}_{2}-\mathrm{H}_{2} \mathrm{O}$ : Applications to $\mathrm{P}-\mathrm{T}$ sections and geothermometry. Contrib. Mineral. Petrol. 2014, 167, 1-19. [CrossRef]

65. Brey, G.P.; Köhler, T. Geothermobarometry in four-phase lherzolites II: New thermobarometers, and practical assessment of existing thermobarometers. J. Petrol. 1990, 31, 1353-1378. [CrossRef]

66. Putirka, K.D. Thermometers and barometers for volcanic systems. In Minerals, Inclusions and Volcanic Processes: Mineralogical Society of America, Reviews in Mineralogy and Geochemistry; Putirka, K.D., Tepley, F., Eds.; Mineralogical Society of America: Chantilly, VA, USA, 2008; Volume 69, pp. 61-120.

67. Deer, W.A.; Howie, R.A.; Zussman, J. An Introduction to Rock Forming Minerals, 2nd ed.; Pearson: Harlow, UK, 1992; 696p.

68. Leake, B.E.; Woolley, A.R.; Arps, C.E.S.; Birch, W.D.; Gilbert, M.C.; Grice, J.D.; Hawthorne, F.F.; Kato, A.; Kisch, H.J.; Krivovichev, V.G.; et al. Nomenclature of amphiboles: Report of the subcommittee on amphiboles of the International Mineralogical Association, Commission on New Minerals and Mineral Names. Can. Mineral. 1997, 35, 219-246. [CrossRef]

69. Hey, M.H. A new review of the chlorites. Mineral. Mag. 1954, 30, 277-292. [CrossRef]

70. Zane, N.; Weiss, Z. A procedure for classifying rock-forming chlorites based on microprobe data. Rend. Fis. Accad. Lincei 1998, 9, 51-56. [CrossRef]

71. Foose, M.P.; Nicholson, S.W. Sulfide Inclusions within the B Chromitite, Stillwater Complex, Montana; Bulletin1674A; USGS: Reston, VA, USA, 1990; pp. D1-D22.

72. Manning, C.E.; Bird, D.K. Hydrothermal clinopyroxenes of the Skaergaard intrusion. Contrib. Mineral. Petrol. 1986, 92, 437-447. [CrossRef]

73. Good, D.J.; Crocket, J.H.; Barnett, R.L. A secondary clinopyroxene-chlorite-spinel assemblage in clinopyroxenite of the Mann Complex, Abitibi Belt, Ontario: An unusual hydrothermal alteration suite. Mineral. Petrol. 1997, 59, 69-90. [CrossRef]

74. Wilson, A.H. The geology of the Great Dyke, Zimbabwe: Crystallization, layering, and cumulate formation in the P1 Pyroxenite of cyclic unit 1 of the Darwendale Subchamber. J. Petrol. 1992, 33, 611-663. [CrossRef]

75. Li, C.; Ripley, E.M.; Sarkar, A.; Shin, D.; Maier, W.D. Origin of phlogopite-orthopyroxene inclusions in chromites from the Merensky Reef of the Bushveld Complex, South Africa. Contrib. Mineral. Petrol. 2005, 150, 119-130. [CrossRef]

76. Raines, M.D. An Assessment of Equilibrium in the Merensky Reef: A Textural, Geochemical and Nd Isotope Study of Coexisting Plagioclase and Orthopyroxene from Winnaarshoek in the Eastern Bushveld Complex, RSA. Unpublished Master's Thesis, Rhodes University, Grahamstown, South Africa, 2014.

77. Robinson, P.T.; Erzinger, J.; Emmermann, R. The composition and origin of igneous and hydrothermal veins in the lower ocean crust-ODP Hole 735B, Southwest Indian Ridge. In ODP, Scientific Results; Natland, J.H., Dick, H.J.B., Miller, D.J., Von Herzen, R.P., Eds.; Texas A\&M University: College Station, TX, USA, 2002; Volume 176, pp. 1-66.

78. Bird, D.K.; Schiffman, P.; Elders, W.A.; Williams, A.E.; McDowell, D. Calc-silicate mineralization in active geothermal systems. Econ. Geol. 1984, 79, 671-695. [CrossRef]

79. Bird, D.K.; Rogers, D.; Manning, C.E. Mineralized Fracture Systems of the Skaergaard Intrusion, East Greenland. Medd. Groenl. Geosci. 1986, 16, 68.

80. Wilson, A.H. The Great Dyke of Zimbabwe. In Layered Intrusions; Cawthorn, R.G., Ed.; Elsevier Science B.V.: Amsterdam, The Netherlands, 1996; pp. 365-402.

81. Van der Merwe, M.J. The layered sequence of the Potgietersrus limb of the Bushveld Complex. Econ. Geol. 1976, 71, 1337-1351. [CrossRef]

82. Parlak, O.; Hoeck, V.; Delaloye, M. Suprasubduction zone origin of the Pozanti-Karsanti ophiolite (southern Turkey) deduced from whole-rock and mineral chemistry of the gabbroic cumulates. In Tectonics and Magmatism in Turkey and the Surrounding Area; Bozkurt, E., Winchester, J.A., Piper, J.D.A., Eds.; Geological Society: London, UK, 2000; Volume 173, pp. 219-234. 
83. Stakes, D.S.; Taylor, H.P., Jr. The northern Samail ophiolite: An oxygen isotope, microprobe, and field study. J. Geophys. Res. 1992, 97, 7043-7080. [CrossRef]

84. Pallister, J.S.; Hopson, C.A. Samail ophiolite plutonic suite: Field relations, phase variation, cryptic variation and layering, and a model of a spreading ridge magma chamber. J. Geophys. Res. 1981, 86, B42593-B42644. [CrossRef]

85. Page, N.J.; Zientek, M.L. Composition of Primary Postcumulus Amphibole and Phlogopite within an Olivine Cumulate in the Stillwater Complex, Montana; No. 1674-A; USGPO; United States Geological Survey: Reston, VA, USA, 1987.

86. Mathison, C.I. Cyclic units in the Somerset Dam layered gabbro intrusion, southeastern Queensland, Australia. Lithos 1987, 20, 187-205. [CrossRef]

87. Mathison, C.I.; Hamlyn, P.R. The McIntosh layered troctolite-olivine gabbro intrusion, East Kimberley, Western Australia. J. Petrol. 1987, 28, 211-234. [CrossRef]

88. Martin, R.F. Amphiboles in the igneous environment. Rev. Mineral. Geochem. 2007, 67, 323-358. [CrossRef]

89. Kesler, S.E. Ore-forming fluids. Elements 2005, 1, 13-18. [CrossRef]

90. Gregory, R.T.; Taylor, H.P., Jr. An oxygen isotope profile in a section of cretaceous oceanic crust, Samail ophiolite, Oman: Evidence for $\delta^{18} \mathrm{O}$ buffering of the oceans by deep $(>5 \mathrm{~m})$ seawater-hydrothermal circulation at mid-ocean ridges. J. Geophys. Res. 1981, 86, 2737-2755. [CrossRef]

91. Chaumba, J.B.; Wilson, A.H. An Oxygen isotope study of the Lower Mafic Succession of the Great Dyke, Zimbabwe. Chem. Geol. 1997, 135, 293-305. [CrossRef]

92. Li, C.; Ripley, E.M.; Oberthür, T.; Miller, J.D.; Joslin, G.D. Textural, mineralogical and stable isotope studies of hydrothermal alteration in the main sulfide zone of the Great Dyke, Zimbabwe and the precious metals zone of the Sonju Lake Intrusion, Minnesota, USA. Miner. Deposita 2008, 43, 97-110. [CrossRef]

93. Prendergast, M.D. Platinum-group minerals and hydrosilicate 'alteration' in the Wedza-Mimosa Platinum Deposit, Great Dyke, Zimbabwe-Genetic and metallurgical implications. Trans. Inst. Min. Metall. 1990, 99, B91-B105.

94. Maier, W.; Määttää, S.; Yang, S.; Oberthür, T.; Lahaye, Y.; Huhma, H.; Barnes, S.-J. Composition of the ultramafic-mafic contact interval of the Great Dyke of Zimbabwe at Ngezi mine: Comparisons to the Bushveld Complex and implications for the origin of the PGE reefs. Lithos 2015, 238, 207-222. [CrossRef]

95. Ohmoto, H.; Goldhaber, M.B. Sulfur and carbon isotopes. In Geochemistry of Hydrothermal Ore Deposits, 3rd ed.; Barnes, H.L., Ed.; J. Wiley and Sons: Hoboken, NJ, USA, 1997; pp. 517-611.

96. Li, C.; Ripley, E.M. Empirical equations to predict the sulfide content of mafic magmas at sulfide saturation and applications to magmatic sulfide deposits. Miner. Deposita 2005, 40, 218-230. [CrossRef]

97. Schoenberg, R.; Nagler, T.F.; Gnos, E.; Kramers, J.D.; Kamber, B.S. The source of the Great Dyke, Zimbabwe, and its tectonic significance: Evidence from Re-Os isotopes. J. Geol. 2003, 111, 565-578. [CrossRef]

98. Mogessie, A.; Stumpfl, E.F.; Weiblen, P.W. The role of fluids in the formation of platinum-group minerals, Duluth Complex, Minnesota: Mineralogic, textural and chemical evidence. Econ. Geol. 1991, 86, 1506-1518. [CrossRef]

99. Ripley, E.M.; Butler, B.K.; Tain, I.N.; Lee, I. Hydrothermal alteration in the Babbitt Cu-Ni Deposit, Duluth Complex: Mineralogy and hydrogen isotope systematics. Econ. Geol. 1993, 88, 679-696. [CrossRef]

100. Severson, M.J. Igneous Stratigraphy of the South Kawishiwi Intrusion, Duluth Complex, Northeastern Minnesota; Technical Report NRRI/TR-93/94; University of Minnesota Duluth, Natural Resources Research Institute: Hermantown, MN, USA, 1994; 210p.

101. Gál, B.; Molnár, F.; Guzmics, T.; Mogessie, A.; Szabó, C.; Peterson, D.M. Segregation of magmatic fluids and their potential in the mobilization of platinum-group elements in the South Kawishiwi intrusion, Duluth Complex, Minnesota-Evidence from petrography, apatite geochemistry and coexisting fluid and melt inclusions. Ore Geol. Rev. 2013, 54, 59-80. [CrossRef]

102. Wilson, A.H.; Chaumba, J.B. Closed system fractionation in a large magma chamber: Mineral compositions of the Websterite Layer and Lower Mafic Succession of the Great Dyke, Zimbabwe. Mineral. Mag. 1997, 61, 153-173. [CrossRef]

103. Chaumba, J.B. The Petrology and Petrogenesis of the Websterite Layer and the Mafic Sequence of the Darwendale Subchamber, Great Dyke, Zimbabwe. Unpublished Master's Thesis, University of Natal, Pietermaritzburg, South Africa, 1995. 
104. Jelsma, H.A.; van der Beek, P.R.; Vinyu, M.L. Tectonic evolution of the Bindura-Shamva greenstone belt (northern Zimbabwe): Progressive deformation around diapiric structures. J. Struct. Geol. 1993, 15, 163-176. [CrossRef]

105. Marshall, D.; Watkinson, D.H.; Farrow, C.E.G.; Molnar, F.; Fouillac, A. Multiple fluid generations in the Sudbury Igneous complex: Fluid inclusion, Ar, O, H, Rb, Sr evidence. Chem. Geol. 1999, 154, 1-19. [CrossRef]

106. Molnar, F.; Watkinson, D.H.; Jones, P.C. Multiple hydrothermal processes in footwall units of the North Range, Sudbury Igneous Complex, Canada, and implications for the genesis of vein-type Cu-Ni-PGE deposits. Econ. Geol. 2001, 96, 1645-1670. [CrossRef]

107. Park, Y.R.; Ripley, E.M.; Miller, J.D.; Li, C.; Mariga, J.; Schafer, P. Stable isotopic constraints on fluid rock interaction and Cu-PGE-S redistribution in the Sonju Lake intrusion, Minnesota. Econ. Geol. 2004, 99, 325-338. [CrossRef]

108. Lundstrom, C. Hypothesis for the origin of convergent margin granitoids and Earth's continental crust by thermal migration zone refining. Geochim. Cosmochim. Acta 2009, 73, 5709-5729. [CrossRef]

109. Lundstrom, C.C.; Marshak, S.; DeFrates, J.; Mabon, J. Alternative processes for developing fabric and mineral compositional zoning in intrusive rocks. Int. Geol. Rev. 2011, 53, 377-405. [CrossRef]

110. Lundstrom, C.C.; Gajos, N. Formation of the PGE reef horizon in the Sonju Lake layered mafic intrusion by thermal migration zone refining. Econ. Geol. 2014, 109, 1257-1269. [CrossRef]

111. Robb, L. Introduction to Ore-Forming Processes; Blackwell Science: Malden, MA, USA, 2005; 384p.

112. Irvine, T.N. Observations on the Origins of Skaergaard Layering; Carnegie Institution of Washington Yearbook: Washington, DC, USA, 1983; Volume 82, pp. 284-289.

113. Boudreau, A.E.; McCallum, I.S. Infiltration metasomatism in layered intrusions-An example from the Stillwater Complex, Montana. J. Volcanol. Geotherm. Res. 1992, 52, 171-183. [CrossRef]

114. Tredoux, M.; Lindsay, N.M.; Davies, G.; McDonald, I. The fractionation of platinum group elements in magmatic systems, with the suggestion of a novel causal mechanism. S. Afr. J. Geol. 1995, 98, 157-167.

115. Glazner, A.F.; Bartley, J.M.; Coleman, D.S.; Gray, W.; Taylor, R.Z. Are plutons assembled over millions of years by amalgamation from small magma chambers? GSA Today 2004, 14, 4-11. [CrossRef]

116. Boudreau, A.E.; Meurer, W.P. Chromatographic separation of the platinum-group elements, gold, base metals and sulfur during degassing of a compacting and solidifying igneous crystal pile. Contrib. Mineral. Petrol. 1999, 134, 174-185. [CrossRef] 